\title{
Insights from an Integrated View of the Biology of Apple Snails (Caenogastropoda: Ampullariidae)
}

Author(s): Kenneth A. Hayes, Romi L. Burks, Alfredo Castro-Vazquez, Philip C. Darby, Horacio Heras, Pablo R. Martín, Jian-Wen Qiu, Silvana C. Thiengo, Israel A. Vega, Takashi Wada, Yoichi Yusa, Silvana Burela, M. Pilar Cadierno, Juan A. Cueto, Federico A. Dellagnola, Marcos S. Dreon, M. Victoria Frassa, Maximiliano Giraud-Billoud, Martín S. Godoy, Santiago Ituarte, Eduardo Koch, Keiichiro Matsukura, M. Yanina Pasquevich, Cristian Rodriguez, Lucía Saveanu, María E. Seuffert, Ellen E. Strong, Jin Sun, Nicolás E. Tamburi, María J. Tiecher, Richard L. Turner, Patricia L. Valentine-Darby \& Robert H. Cowie

Source: Malacologia, 58(1-2):245-302.

Published By: Institute of Malacology

DOI: http://dx.doi.org/10.4002/040.058.0209

URL: http://www.bioone.org/doi/full/10.4002/040.058.0209

BioOne (www.bioone.org) is a nonprofit, online aggregation of core research in the biological, ecological, and environmental sciences. BioOne provides a sustainable online platform for over 170 journals and books published by nonprofit societies, associations, museums, institutions, and presses.

Your use of this PDF, the BioOne Web site, and all posted and associated content indicates your acceptance of BioOne's Terms of Use, available at www.bioone.org/page/ terms of use.

Usage of BioOne content is strictly limited to personal, educational, and non-commercial use. Commercial inquiries or rights and permissions requests should be directed to the individual publisher as copyright holder. 


\title{
INSIGHTS FROM AN INTEGRATED VIEW OF THE BIOLOGY OF APPLE SNAILS (CAENOGASTROPODA: AMPULLARIIDAE)
}

Kenneth A. Hayes $1,2,3^{*}$, Romi L. Burks ${ }^{4}$, Alfredo Castro-Vazquez ${ }^{5}$, Philip C. Darby ${ }^{6}$, Horacio Heras7, Pablo R. Martín', Jian-Wen Qiu9, Silvana C. Thiengo10, Israel A. Vega5,11, Takashi Wada12, Yoichi Yusa $^{13}$, Silvana Burela8, M. Pilar Cadierno7, Juan A. Cueto ${ }^{5}$, Federico A. Dellagnola5, Marcos S. Dreon7,14, M. Victoria Frassa7, Maximiliano Giraud-Billoud5, Martín S. Godoy5, Santiago Ituarte ${ }^{7}$, Eduardo Koch5, Keiichiro Matsukura2,12, M. Yanina Pasquevich7, Cristian Rodriguez ${ }^{5}$, Lucía Saveanu' 8 , María E. Seuffert8, Ellen E. Strong ${ }^{3}$, Jin Sun 9 , Nicolás E. Tamburi8, María J. Tiecher8, Richard L. Turner ${ }^{15}$, Patricia L. Valentine-Darby ${ }^{16}$ \& Robert H. Cowie ${ }^{2}$

\begin{abstract}
Apple snails (Ampullariidae) are among the largest and most ecologically important freshwater snails. The introduction of multiple species has reinvigorated the field and spurred a burgeoning body of research since the early 1990s, particularly regarding two species introduced to Asian wetlands and elsewhere, where they have become serious agricultural pests. This review places these recent advances in the context of previous work, across diverse fields ranging from phylogenetics and biogeography through ecology and developmental biology, and the more applied areas of environmental health and human disease. The review does not deal with the role of ampullariids as pests, nor their control and management, as this has been substantially reviewed elsewhere. Despite this large and diverse body of research, significant gaps in knowledge of these important snails remain, particularly in a comparative framework. The great majority of the work to date concerns a single species, Pomacea canaliculata, which we see as having the potential to become a model organism in a wide range of fields. However, additional comparative data are essential for understanding this diverse and potentially informative group. With the rapid advances in genomic technologies, many questions, seemingly intractable two decades ago, can be addressed, and ampullariids will provide valuable insights to our understanding across diverse fields in integrative biology.

Key words: behavior, benthic macroinvertebrates, development, dormancy, ecology, evolution, freshwater, Gastropoda, immune system, invasive species, parasitology, reproduction, symbiosis.
\end{abstract}

1 Department of Biology, Howard University, 415 College St., Washington, DC. 20059, U.S.A.

2 Pacific Biosciences Research Center, University of Hawaii, 3050 Maile Way, Gilmore 408, Honolulu, Hawaii 96822, U.S.A.

3 Smithsonian Institution, National Museum of Natural History, P.O. Box 37012, MRC 163, Washington, D.C. 20013-7012, U.S.A.

4 Department of Biology, Southwestern University, 1001 East University Avenue, Georgetown, Texas 78626, U.S.A.

5 Instituto de Fisiología (FCM-UNCuyo) and Laboratorio de Fisiología (IHEM-CONICET), Casilla de Correo 33, 5500 Mendoza, Argentina.

6 Department of Biology, University of West Florida, 11000 University Parkway, Pensacola, Florida 32514, U.S.A.

7 Instituto de Investigaciones Bioquímicas de La Plata (INIBIOLP, CONICET, Universidad Nacional de La Plata), Facultad de Ciencias Médicas, 60 y 120, 1900 La Plata, Argentina.

8 Laboratorio de Ecología, INBIOSUR (Universidad Nacional del Sur-CONICET), Bahía Blanca, Argentina.

9 Department of Biology, Hong Kong Baptist University, 224 Waterloo Road, Kowloon, Hong Kong.

10Laboratório de Malacologia, Instituto Oswaldo Cruz/Fiocruz, Av. Brasil 4365, 21040-900 Rio de Janeiro, RJ, Brasil.

${ }_{11}$ Área de Biología, Facultad de Ciencias Exactas y Naturales, Universidad Nacional de Cuyo, Mendoza, Argentina.

12NARO Kyushu Okinawa Agricultural Research Center, Suya 2421, Koshi, Kumamoto 861-1192, Japan.

13Faculty of Science, Nara Women's University, Kitauoya-nishi, Nara 630-8506, Japan.

${ }^{14}$ Comisión de Investigaciones Científicas (CIC), La Plata, Argentina.

15Biological Sciences Department, Florida Institute of Technology, 150 W. University Blvd., Melbourne, Florida 32901, U.S.A.

16The Pomacea Project, Inc., Pensacola, Florida, U.S.A

* Corresponding author: kenneth.hayes@howard.edu 
TABLE OF CONTENTS

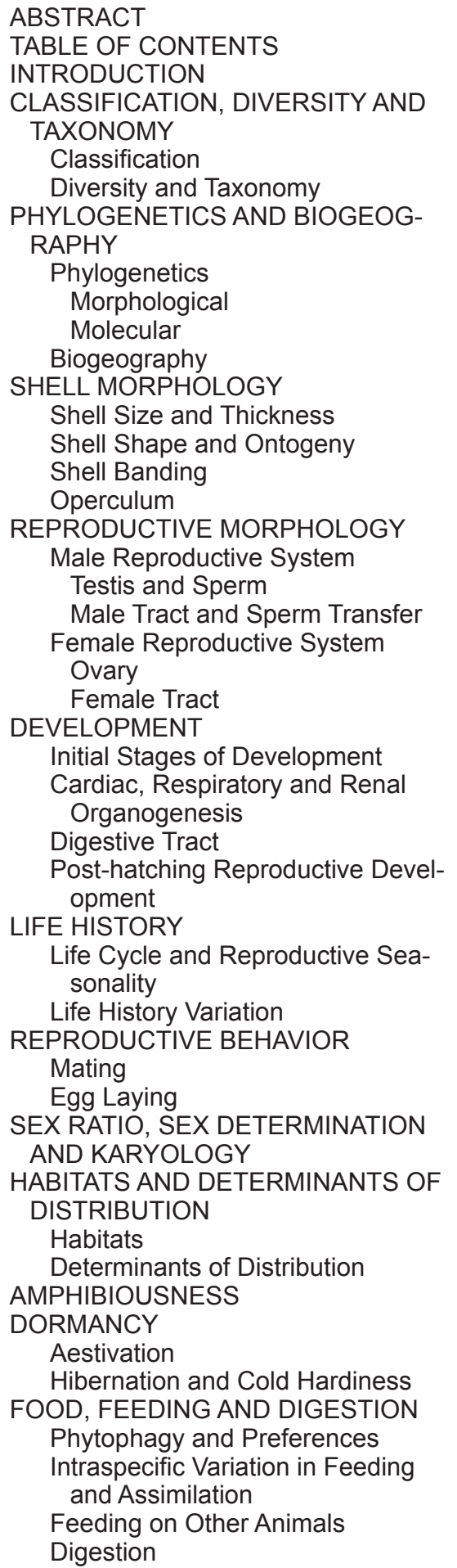

PREDATORS AND PREDATOR
AVOIDANCE

Predators 269

Predator Avoidance 270

EGG PROTEINS: STRUCTURE AND 270

ROLE IN DEFENSE

Perivitellin Structure and Synthe- 271 sis

Perivitellin Functions 271

Evolutionary and Ecological Impli- 272 cations of Egg Defenses

SYMBIOTIC ASSOCIATIONS 273

Epibiotic Organisms 273

Endosymbiotic Animals 273

Endosymbiotic Protists and $\quad 275$ Bacteria

Intracellular Pigmented Corpus- $\quad 275$ cles in the Midgut Gland

IMMUNE DEFENSES 276

Ampullariid Hemocytes 276

Hemocyte-producing Organs and/ 276 or Immune Barriers

ENVIRONMENTAL HEALTH AND 277

POLLUTION

Accumulation of Pollutants $\quad 277$

Toxicity of Pollutants to Apple $\quad 278$ Snails

Mechanisms of Toxicity 278

HUMAN HEALTH CONCERNS 279

Angiostrongyliasis $\quad 279$

Cercarial Dermatitis 280

Echinostomiasis 280

CONCLUSION AND FUTURE RE- $\quad 281$

SEARCH OPPORTUNITIES

ACKNOWLEDGEMENTS 282

LITERATURE CITED 282

\section{INTRODUCTION}

Apple snails (Ampullariidae) are freshwater and amphibious snails predominantly distributed throughout the humid tropics and subtropics of Africa, the Americas and Asia (Berthold, 1991), where they often constitute a major portion of the native freshwater molluscan fauna (Fig. 1). They are commonly referred to as apple snails because of their large, round shells and include the largest of all freshwater snails. The family belongs to the Caenogastropoda, a large and diverse clade containing roughly $60 \%$ of living Gastropoda (Ponder et al., 2008).

Increasing interest in apple snail research has been driven in part by the introduction of several species as aquarium pets or food to many locations around the world, where they frequently have become major agricultural and 


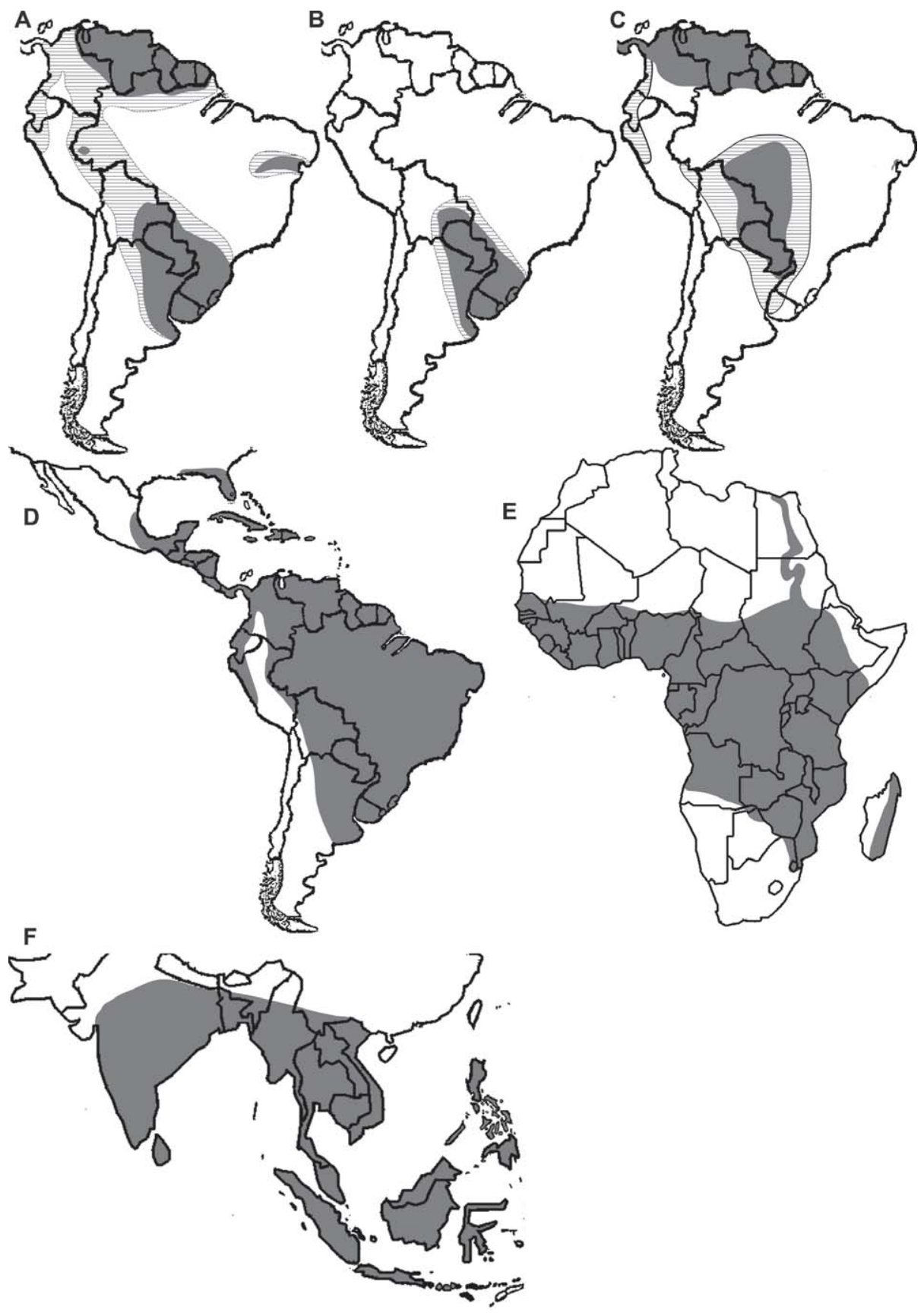

FIG. 1. Known (shaded grey) and probable (hashed) native distributions of Asolene (A), Felipponea (B), Marisa (C), Pomacea (D), Lanistes and Pila in Africa (E), and Pila in Asia (F). Afropomus and Lanistes are restricted to western Africa in Sierra Leone and Liberia, and the genus Forbesopomus is known only from a single location in the Philippines. Known distributions of New World taxa determined from literature and historical and recent collection data. Probable distributions estimated based on habitat suitability. Distributions for Lanistes and Pila based primarily on historical and recent collections. 
environmental pests (Cowie, 2002; Joshi \& Sebastian, 2006; Cowie \& Hayes, 2012). This interest has been further fueled by questions surrounding the origin of several novel anatomical and behavioral characteristics, some associated with the transition from aquatic to terrestrial habitats (Hayes et al., 2009a). Addressing these questions in an integrative framework may provide insights fundamental to understanding the evolutionary biology of snails and freshwater taxa more generally (Hayes et al., 2009a), and has the potential to elevate apple snails to a valuable model system.

Cowie (2002) reviewed what was then known of apple snail biology, focusing on their ecology and behavior, impacts as pests and approaches to managing them. At the time of that review, the true identity of the pest species was not well understood, but this has since been clarified (Rawlings et al., 2007; Hayes et al., 2008, 2012; Tran et al., 2008). Since then, there has been a burgeoning of studies, primarily by South American, Asian and North American authors, focused mainly on the pest species Pomacea canaliculata (Lamarck, 1822) and Pomacea maculata Perry, 1810. The present review provides an update and extension of Cowie (2002) and focuses on studies on fundamental biology and applied topics in human health and ecotoxicology undertaken in the intervening years, as well as on topics not covered in that review, but excluding pest management, which has been covered extensively by Joshi \& Sebastian (2006).

Much of the review focuses inevitably on species of Pomacea, most notably Pomacea canaliculata. However, various species of Pila are also frequently mentioned. To avoid confusion, we only abbreviate Pomacea to "P.", always spelling out Pila in full.

\section{CLASSIFICATION, DIVERSITY AND TAXONOMY}

\section{Classification}

Ampullariids are basal members of the Caenogastropoda. The family Ampullariidae Gray, 1824 (junior synonym: Pilidae - Cowie, 1997; ICZN, 1999), is in the superfamily Ampullarioidea within the informal group Architaenioglossa, which also includes the Cyclophoroidea and Viviparoidea (Bouchet \& Rocroi, 2005). The Architaenioglossa has been resolved as paraphyletic in higher-order analyses using both molecular and morphological data (e.g., Harasewych et al., 1998; Colgan et al., 2003, 2007; Ponder et al., 2008). The Campaniloidea also may be closely related. Although marine ancestry of the architaenioglossan taxa is assumed by most, relationships among the four superfamilies and the resolution of the base of the Caenogastropoda remain unresolved (Ponder \& Lindberg, 1997; McArthur \& Harasewych, 2003; Strong, 2003; Simone, 2004; Colgan et al., 2003, 2007; Jørgensen et al., 2008; Ponder et al., 2008; Hayes et al., 2009b).

\section{Diversity and Taxonomy}

There are ten genera with approximately 120 species currently considered valid within the Ampullariidae. One of these genera, Pseudoceratodes (African, fossil only), is included in the family only tentatively (Berthold, 1991). The great majority of the remaining species are referred to just three genera (Table 1): Pila (Ampullaria and Ampullarius are junior synonyms - Cowie, 1997; ICZN, 1999), Lanistes and Pomacea. The remaining six genera each contain only one or a few species (Table 1).

Ampullariid taxonomy has relied almost exclusively on shell morphology. However, it has been extremely confused because of the gross morphological similarity within major groups accompanied by considerable intra-specific variation. Consequently, species boundaries have been very difficult to assess based solely on conchology. Berthold (1991) published very detailed descriptions not only of the shells but also of the soft anatomy of a selection of 36 species spanning the family. This work remains the most detailed analysis of ampullariid morphology to date, although the anatomy of Pomacea canaliculata and P. maculata has recently been redescribed in detail by Hayes et al. (2012), with significant modification to the interpretations of Berthold (1991). Additional anatomical information has been provided for Pomacea diffusa Blume, 1957, P. figulina (Spix in Wagner, 1827), P. glauca (Linnaeus, 1758), $P$. lineata (Spix in Wagner, 1827), $P$. scalaris (d'Orbigny, 1835) and P. sordida (Swainson, 1823) by Thiengo et al. (2011). Hayes et al. (2012) also synonymized the genus Pomella (which contained three valid species; Cowie \& Thiengo, 2003) with Pomacea. In addition, these authors treated a number of species as synonyms of $P$. canaliculata, and others, including $P$. insularum (d'Orbigny, 1835), as synonyms of $P$. maculata. In the latter case, be- 
TABLE 1. Numbers of nomenclaturally available species-group names and numbers of taxa of Ampullariidae (excluding fossil taxa).

\begin{tabular}{llcccc}
\hline \multicolumn{1}{c}{ Genus } & \multicolumn{1}{c}{ Distribution } & $\begin{array}{c}\text { Currently valid } \\
\text { species }^{1}\end{array}$ & $\begin{array}{c}\text { Estimated actual } \\
\text { species diversity2 }\end{array}$ & $\begin{array}{c}\text { Subspecies, } \\
\text { varieties, etc. }\end{array}$ & Synonyms \\
\hline Afropomus & Africa & 1 & 1 & 1 & - \\
Asolene & South America & 8 & 8 & 2 & 14 \\
Felipponea & South America & 3 & 3 & - & - \\
Forbesopomus & Asia & 1 & 1 & - & - \\
Lanistes & Africa & 43 & 20 & 16 & 34 \\
Marisa & South America & 2 & 3 & - & 6 \\
Pila & Africa and Asia & 29 & 30 & 16 & 84 \\
Pomacea & South, Central and & 96 & 50 & 22 & 112 \\
Saulea & North America & & & & - \\
Total & Africa & 1 & 1 & 57 & 250 \\
\hline
\end{tabular}

1For the New World, from Cowie \& Thiengo (2003), and taking into account changes subsequent to that publication, as tabulated by Cowie (in preparation); and for the Old World, Cowie (in preparation). Homonyms considered by Cowie \& Thiengo (2003) and Cowie (in preparation) to represent taxonomically valid species and infraspecific taxa are counted as such.

2From Berthold (1991), Hayes \& Cowie (unpublished).

cause Hayes et al. (2012) designated the same specimen as the neotype of $P$. maculata and as the lectotype of $P$. insularum, these become objective synonyms and the name insularum d'Orbigny, 1835, is no longer valid.

\section{PHYLOGENETICS AND BIOGEOGRAPHY}

\section{Phylogenetics}

\section{Morphological}

The first morphological phylogenetic analyses of ampullariids were those of Berthold (1991), who included conchological and anatomical characters, as well as characters of the eggs and reproductive behavior (i.e., deposition of egg masses above or below the water surface). The analyses were criticized by Bieler (1993) owing to Berthold's use of Hennigian argumentation without formal presentation of a character state matrix; when Bieler (1993) re-analyzed the data, a tree that differed in certain fundamental aspects resulted, most notably in the relative positions of Saulea and Afropomus and in the monophyly/paraphyly of Pomacea (Hayes et al., 2009b). A more recent and extensive character set (Simone, 2004) included only ten species, all from the New World, and produced a unique ar- rangement with Felipponea and Asolene nested within a paraphyletic Pomacea, and Marisa as sister to this assemblage.

\section{Molecular}

Jørgensen et al. (2008) published the first major molecular phylogeny of Ampullariidae, with a focus on African species and only three New World and four Asian species. Their fivelocus analysis of 21 species recovered Old and New World taxa as non-monophyletic groups. Using a similar suite of markers (COI, 16S, H3, $18 \mathrm{~S}$ and elongation factor 1 alpha instead of 28S), Hayes et al. (2009b) analyzed 40 species representing nine ampullariid genera and potential outgroups that included five viviparids, the only extant campanilid, and a cyclophorid. Their results contradicted those of Jørgensen et al. (2008) and showed that the Old and New World ampullariids are indeed reciprocally monophyletic. However, although four Old World genera (Afropomus, Saulea, Pila, Lanistes) were recovered as monophyletic, only Asolene was monophyletic among the five New World genera represented by more than a single species, with Marisa paraphyletic and Pomella (now a junior synonym of Pomacea: Hayes et al., 2012), nested within the polyphyletic Pomacea (Fig. 2). 
Consistent with Jørgensen et al. (2008), Lanistes and Pila were robustly supported as reciprocally monophyletic sister clades, a relationship not supported by the morphological analyses (Berthold, 1991; Bieler, 1993). A monophyletic Pila consisted of two stronglysupported sister clades, one Asian and one African. Saulea was not supported as the sister taxon to New World ampullariids (Jørgensen

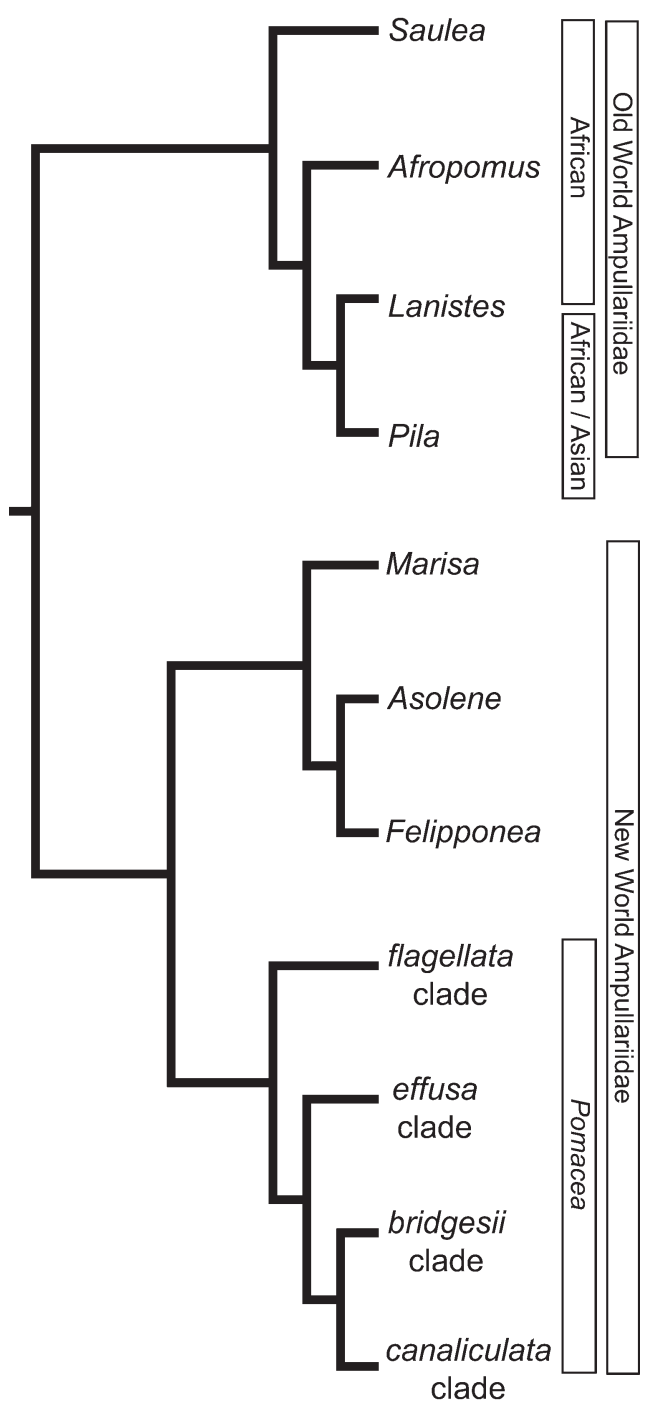

FIG. 2. Phylogenetic tree showing generic relationships within Ampullariidae and among major clades within the New World genus Pomacea. Redrawn from Hayes et al. (2009b) and Hayes (2009). et al., 2008), but was recovered as the basal member of the Old World ampullariids, consistent with the reanalysis of Berthold's (1991) data by Bieler (1993). The genus Forbesopomus has not been included in any phylogenetic analysis. Hayes et al. (2009b) demonstrated the importance of outgroup choice for inferring relationships among ampullariid genera, and for understanding evolutionary patterns within the group broadly. The remaining uncertainty regarding family-level relationships among basal caenogastropods is an area ripe for research incorporating additional anatomical and genomic data.

In early 2003, 20 years after the initial release of NCBl's (National Center for Biotechnology Information) GenBank sequence database, there were only nine ampullariid sequences, including three mitochondrial and six nuclear ribosomal, from individuals representing four Pomacea spp. and Marisa cornuarietis (Linnaeus, 1758). As of May 2014, a little more than a decade later, ampullariid sequence data on GenBank included 1,050 entries representing all extant genera except Forbesopomus. The majority of these $(69 \%)$ are mitochondrial gene fragments (e.g., COI, 16S) commonly used in phylogenetic and phylogeographic analyses (e.g., Rawlings et al., 2007; Jørgensen et al., 2008; Hayes et al., 2008, 2009b; Bian et al., 2013) representing 54 species.

The advent of next-generation sequencing techniques has made feasible the generation of large amounts of genomic data, such as transcriptomes from whole organisms or from different organs and cost effective. Sun et al. (2012a) have made a significant step forward by conducting a de novo assembly of the transcriptome of $P$. canaliculata. They reported the identification of 128,436 unigenes with an average length of $419 \mathrm{bp}$ and listed a number of genomic resources that may be useful for ecological and physiological studies including 2,439 unigenes with transposable elements, 3,196 microsatellites and 15,412 single-nucleotide polymorphisms. However, much of these data are not available on public databases and remain uncharacterized without an annotated expressed sequence tag database and comparative data from other closely related taxa. More recently, Sun et al. (2013) have made further advances through identification of 1,040 proteins from Pomacea canaliculata, among which more than 50 were differentially expressed under active and a estivating conditions. These efforts, combined with those of a number of ongoing genomic 
research projects, will soon yield vast amounts of data that will provide broad insights into the evolution and ecology of ampullariids.

\section{Biogeography}

Ampullariids probably originated from Gondwanan lineages that inhabited what is now Africa (Hayes et al., 2009b). Although fossil records are scarce (e.g., Prashad, 1925a; Pilsbry \& Bequaert, 1927; Fischer, 1963; Boss \& Parodiz, 1977; Martín \& De Francesco, 2006), the Gondwanan origin is supported in part by the distribution of the two most basal genera in the family, Saulea and Afropomus, in current day Sierra Leone and Liberia on the African west coast, and the presence in Africa of two remaining Old World genera Lanistes and Pila. New World taxa (Felipponea, Asolene, Marisa and Pomacea) evolved in South and Central America after the South American continent split from Africa in the early Cretaceous (Hayes et al., 2009b).

The estimated timing of the split between the African and Asian clades of Pila occurred after the separation of Madagascar and India from Africa (Hayes et al., 2009b), which does not support the Out-of-India dispersal hypothesis (McKenna, 1973) that has been suggested to account for many Asian biotic elements with Gondwannan origins. Thus, if Pila originated in Africa (Berthold, 1991), instead of rafting on the Indian land mass, it may have reached Asia via North Africa and the Middle East. Alternatively, Pila originated in Asia from an unknown ancestor, subsequently dispersing into Africa. The finding of a 160 Mya ampullariid operculum in China (Wang, 1984) is more consistent with this latter hypothesis. This pattern of sister clades in Africa and Asia is seen in other groups (e.g., Bossuyt \& Milinkovitch, 2001; Rutschmann et al., 2004; Sparks, 2004), but additional sampling of Asian and African lineages and the incorporation of biogeographic, anatomical and molecular data are necessary to evaluate the various hypotheses above (Hayes et al., 2009b).

\section{SHELL MORPHOLOGY}

Until recently, gross shell morphology of ampullariids has been the main feature on which their taxonomy has been based and is therefore well characterized (Fig. 3). Here we focus on recent advances in understanding and quantifying various aspects of shell morphology and variation, previously reviewed by Estebenet et al. (2006) for South American species.

\section{Shell Size and Thickness}

Apple snails range greatly in size and include the largest freshwater snails, with the shell of $P$. maculata capable of reaching $17 \mathrm{~cm}$ in maximum dimension (Cowie et al., 2006). In contrast, adults of $P$. curumim Simone, 2004, rarely grow larger than the size of $P$. urceus (Müller, 1774) hatchlings (10.5 mm on average; Burky, 1974; Simone, 2004). Shells range from very thick and porcelain-like (e.g., Asolene spp., Felipponea spp.) to much thinner (e.g., certain populations of Pomacea), and in P. papyracea (Spix in Wagner, 1827) they are almost devoid of calcium carbonate, with a very high relative content of organic matter and a thick periostracum (Berthold, 1989; Brown, 1994; Perera \& Walls, 1996; Hayes, 2009). Shell thickness is highly variable within some species of Pomacea, increasing with calcium content and $\mathrm{pH}$ of the water (Glass \& Darby, 2009) and decreasing with growth rate (Estebenet \& Martín, 2003; Estebenet et al., 2006). Release of lactic acid generated by anaerobic metabolism during aestivation corrodes calcium carbonate and reduces the shell weight of Pila globosa (Swainson, 1822) by $5.25 \%$ after five months (Haniffa, 1978). The shells of males tend to be thicker than those of females in $P$. canaliculata, probably because of the investment of calcium in the egg shells and perivitelline fluid (Cazzaniga, 1990; Estebenet \& Martín, 2003; Tamburi \& Martín, 2012) or perhaps because of their lower growth rates (Estebenet et al., 2006; Tamburi \& Martín, 2012).

\section{Shell Shape and Ontogeny}

Most apple snails are globose in shape and dextrally coiled, with the notable exception of species of Marisa, which are planispiral, and species of Lanistes, which are dextral but hyperstrophic and thus outwardly appear sinistral (Fig. 3). Although the globose bauplan places a general constraint on shell shape, some species express many variations on this theme, resulting in significant confusion for their shell-based taxonomy. In P. canaliculata, the inter-population variation has both a genetic and an environmental basis (Estebenet \& Martín, 2003). Sexual dimorphism is also well known in $P$. canaliculata. The shell of female $P$. canaliculata is relatively more globose and 
with a broader body whorl than that of males (Tamburi \& Martín, 2012); this dimorphism is not affected by growth rate, while the relative aperture width increases with growth rate in both sexes. Hanning (1979) showed sexual dimorphism in some populations of $P$. paludosa (Say, 1829). The shell of $P$. canaliculata has been studied recently using geometric morphometrics (Tabugo et al., 2010; Torres et al., 2011; Moneva et al., 2012; Tamburi \& Martín, 2013) to disentangle the relationship between size and shape. Both sexes exhibit static allometry (i.e., adults at the same stage of maturity but of different sizes have different shapes); spire height decreases with size in both sexes, whereas aperture and body whorl size increase with size in males and females, respectively (Tamburi \& Martín, 2013).

Changes in shape through ontogeny have only been studied by Estebenet (1998) in P. canaliculata and Youens \& Burks (2008) in $P$. maculata. In the former, many dimensions of the shell show slightly allometric growth relative to shell length and hence shell shape changes gradually during ontogeny. However, there is a clear change in growth pattern in the operculum and aperture of males (Estebenet et al., 2006).

\section{Shell Banding}

Many species exhibit a pattern of dark spiral bands that varies considerably both within and among species. Some species consistently lack bands, for example Pomacea scalaris (d'Orbigny, 1835), P. papyracea, P. curumin and Pila virescens (Deshayes, in Bory de Saint Vincent, 1824) [Pila polita (Deshayes, 1830) is an objective junior synonym of Pila virescens; Cowie \& Héros, 2012] (Keawjam, 1986; Simone, 2004). Unbanded individuals also often appear in normally banded species, for example M. cornuarietis, P. canaliculata, Pila pesmei (Morlet, 1889) and Pila gracilis (Lea, 1856) (Keawjam, 1986; Dillon, 2002; Estebenet et al., 2006). At least in $P$. canaliculata, the bands are not in the periostracum, but are the result of pigments produced by specialized cells in the

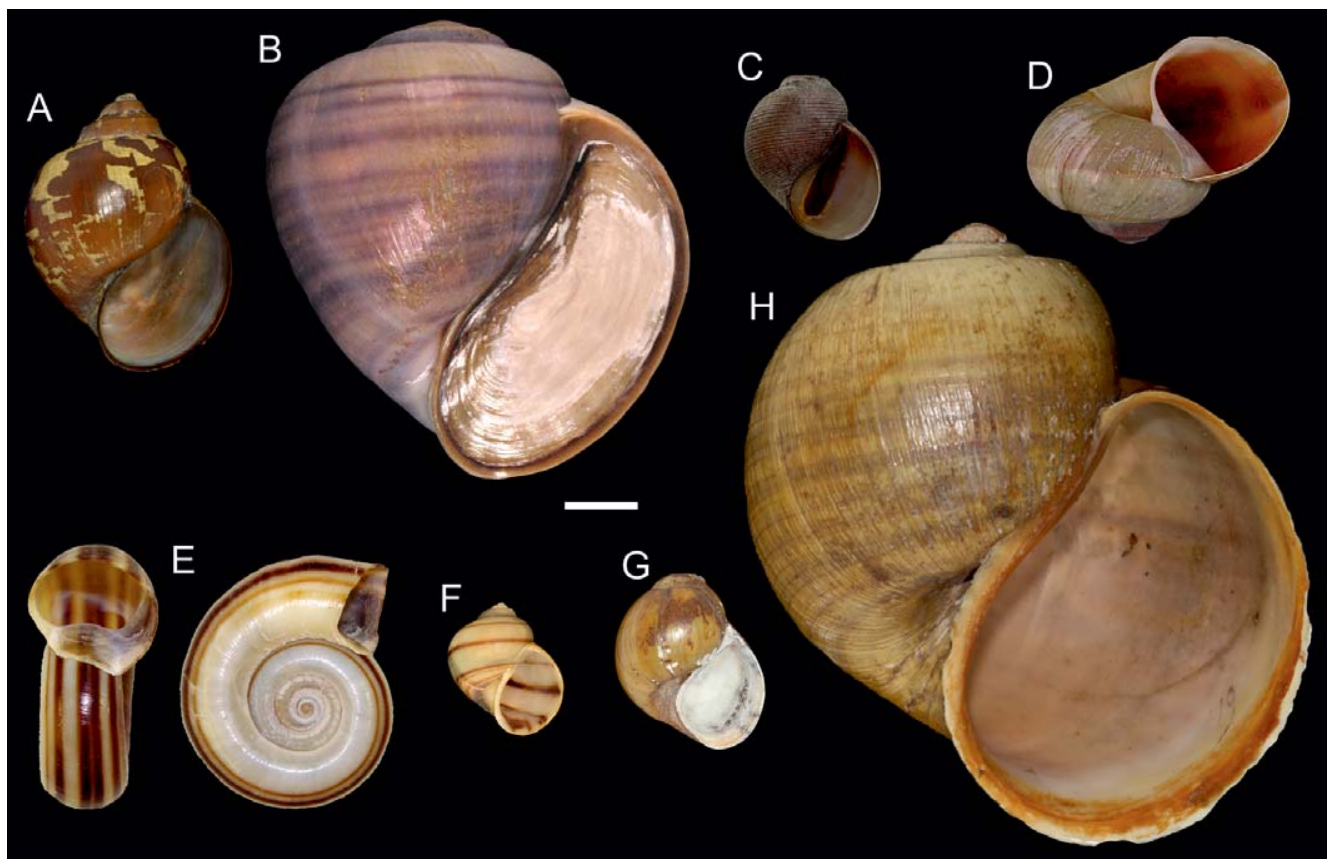

FIG. 3. Type species of extant Ampullariidae genera (except Forbesopomus) showing the diversity of shell morphology in the family. A: Saulea vitrea; B: Pila ampullacea; C: Afropomus balanoidea; D: Lanistes carinatus; E: Marisa cornuarietis; F: Asolene platae; G: Felipponea neritiniformis; H: Pomacea maculata. Scale bar = $1 \mathrm{~cm}$; Photos: Hayes; except B: J.-P. Pointier and D: Muséum National d'Histoire Naturelle, Paris. 
mantle margin and deposited in the outer layer of the shell (Estebenet et al., 2006). Banding seems to be controlled by simple Mendelian inheritance, with the unbanded condition recessive (Dillon, 2002; Yusa, 2004a). However, the environment may also influence the expression of banding, with bands often appearing, disappearing or changing in intensity coincident with strong growth lines (Estebenet et al., 2006). Saulea vitrea (Born, 1778) exhibits a quite different banding pattern, with highly variable coaxial zigzag brown and yellow bands, or may lack bands entirely (Brown, 1994).

\section{Operculum}

A calcified operculum is present only in the genus Pila, with all other ampullariids possessing a proteinaceous, horny operculum. The adult operculum of Pomacea maculata is thicker and more rigid than that of $P$. canaliculata or Asolene spp. (Bachmann, 1960; Hayes et al., 2012). In contrast to $P$. maculata, the flexible edge of the operculum in $P$. canaliculata enables it to seal the shell hermetically, but is not as effective for this purpose in larger $P$. maculata with much thicker operculae (Bachman, 1960; Yoshida et al., 2014). However, even in cases in which it does form a substantial seal, some water is still lost during aestivation (Little, 1968; Giraud-Billoud et al., 2011). In P. canaliculata, the operculum of hatchlings and juveniles of both sexes is concave (Estebenet et al., 2006; Gamarra-Luques et al., 2013). The female operculum remains concave throughout life, but becomes convex toward the posterior margin in males as the animal grows (Estebenet et al., 2006). This change in shape of the male operculum starts when shell length reaches 15-20 mm (Gamarra-Luques et al., 2013).

\section{REPRODUCTIVE MORPHOLOGY}

Rather than describing the complete internal anatomy of ampullariids in detail, which has been covered elsewhere (e.g., Hylton Scott, 1958; Andrews, 1964; Berthold, 1991; Catalán et al., 2002; Hayes et al., 2012; GamarraLuques et al., 2013), this section summarizes key recent advances in the understanding of the structure and function of the reproductive system. This system deserves special attention, as reproductive biology has significance for understanding biogeographical patterns, invasion biology and possibly the evolution of the amphibious habit seen in most ampullariids. The majority of studies have focused on $P$. canaliculata, and unless otherwise indicated, descriptions refer to this species.

\section{Male Reproductive System}

\section{Testis and Sperm}

The male gonad is a sponge-like mass of interconnected tubules that are delimited by a continuous layer of Sertoli cells (= tubular somatic cells) (Gamarra-Luques et al., 2006) that are flattened rather than columnar, as in other caenogastropods (Buckland-Nicks \& Chia, 1986). The large ovoid nuclei of Sertoli cells contain one or more conspicuous nucleoli (Gamarra-Luques et al., 2006) and deep invaginations (Winik et al., 2009), and are polyploid, with 4 to 64 times the haploid nuclear DNA content (Cueto et al., 2006). The Sertoli cell cytoplasm contains abundant smooth endoplasmic reticulum and multilamellar bodies (Winik et al., 1994) made up of circularly arranged membranes. No interstitial epithelioid cells similar to the androgen-secreting interstitial cells of vertebrates have been observed (Gamarra-Luques et al., 2006).

The spermatogenic epithelium is arranged in nests of germinal cells at the same developmental stage. However, development is markedly asynchronous among contiguous nests (Gamarra-Luques et al., 2006), assuring continuous sperm production during the breeding season. This may be correlated with the repeated copulations (two to three per week) observed in reproductively active snails (Albrecht et al., 1996) and may contribute to the rapid growth of invasive populations.

As in many caenogastropods, the testis of $P$. canaliculata produces fertile sperm ("eupyrene sperm" or "eusperm"), as well as infertile "apyrene" and "oligopyrene" parasperm that lose all or part of their chromatin during spermiogenesis, respectively. Among ampullariids, parasperm have also been reported in $P$. maculata (Sachwatkin, 1920) and Asolene pulchella (Anton, 1838) (Tiecher et al., 2014). Eupyrene sperm in $P$. canaliculata result from a typical spermatogenic process and are of the basic monoflagellate "introsperm" type (Rouse \& Jamieson, 1987; Catalán et al., 1997). While eusperm are only able to produce erratic lateral movements in testicular squashes, the highly motile fusiform parasperm, lacking chromatin and resembling those of other gastropods, are propelled by three to five flagellae (Buckland- 
Nicks, 1998; Hodgson, 1999; Winik et al., 2001). They are produced at an apparently lower rate than eusperm (Winik et al., 2001).

Pomacea canaliculata also produces monoflagellate oligopyrene parasperm that are unique among known gastropod sperm. They are similar to the externally fertilizing "ectaquasperm" (Rouse \& Jamieson, 1987) found in the Radiata and many Bilateria and may be produced by a truncation of euspermiogenesis, during which an ephemeral acrosome is formed at the anterior cell pole, by loss of contact with Sertoli cell projections (Buckland-Nicks \& Scheltema, 1995; Winik et al., 2009).

The functional role of parasperm, particularly in the context of sperm competition and paternity assurance, is a matter of speculation (Buckland-Nicks, 1998; Till-Bottraud et al., 2005). In P. canaliculata, mating with a second male displaces sperm deposited by a previous one (Yusa, 2004a), and both eusperm and parasperm from the second male are likely to participate in displacing rival sperm.

\section{Male Tract and Sperm Transfer}

Sperm produced in the testis are transported to the tip of the penis along a path that comprises two distinct segments: (1) gonoduct derivatives, that is, vas deferens, seminal vesicle, prostate and genital papilla; and (2) mantle edge derivatives, that is, the copulatory apparatus, which is uniquely derived in the family, and varies among and sometimes within genera and hence is of considerable taxonomic utility (Berthold, 1991; Hayes et al., 2012).

As there is no direct connection between the genital papilla at the anterior end of the prostate, and the copulatory apparatus, sperm are deposited in a "sperm pit" (Andrews, 1964; Berthold, 1989) at the base of the copulatory apparatus, and from there are drawn, presumably through muscular contraction, into the spermiduct that extends the length of the penial complex. The copulatory apparatus is composed of a penial sheath and a penis (or a penial complex) in all studied species (Berthold, 1989). The penial sheath is short and nonglandular in Afropomus, Saulea and Lanistes (Berthold, 1989; Hayes, 2009), larger but "delicate" in Pila (Prashad, 1925b; Andrews, 1964) and stout and muscular in Marisa and Pomacea (Hylton Scott, 1958; Andrews, 1964; Berthold, 1989; Schulte-Oehlmann et al., 1994; Hayes et al., 2012; Giraud-Billoud et al., 2013a).

When present, there is considerable diversity among species in the number, structure and placement of penial sheath glands. An "outer gland" embedded at the sheath's base in Pila, Marisa and Pomacea extrudes quantities of a mucous secretion through an anterior duct during copulation, a "nuptial gift" eaten by the female, at least in P. canaliculata (Burela \& Martín, 2007, 2014). There may also be one or more superficial glands lined with irregularly textured epithelia on the right margin of the penial sheath groove, which differ among genera and species (Hayes, 2009). They have been given different names by different authors reflecting conflicting interpretations about the number and homology of these glands (Table 2).

In their studies of the copulatory apparatus of $P$. canaliculata, Giraud-Billoud et al. (2013a) observed branched microvilli at the surface of the distal gland, which at the nanoscale level increase adhesion of this gland when inserted into the female's mantle cavity during copulation. A secretion composed of coarse protein granules may also play a role in enhancing adhesion, as suggested by Andrews (1964).

The penial complex comprises a muscular penial bulb (absent in Old World taxa) and a long penis that contains an open (Old World) or a closed (New World) spermiduct (Berthold, 1991). When at rest, the slender penis is enclosed in the penial pouch, which has an opening through which the penis passes to lie within the groove of the penial sheath (Hayes et al., 2012; Giraud-Billoud et al., 2013a). In Pomacea species the muscular penial bulb may also play a role in pumping fluid within the hemolymphatic spaces of the penis to deploy it from its resting coiled position (Giraud-Billoud et al., 2013a). However, the lack of the penial bulb in Old World taxa leaves the question of sperm transfer and penis deployment incompletely answered with regard to ampullariid functional morphology.

\section{Female Reproductive System}

\section{Ovary}

The ovary forms a layer of arborescent tubules beneath the mantle epithelium (Thiengo, 1987, 1989; Thiengo et al., 1993). The tubules are lined by the germinal epithelium, composed of Sertoli cells and oogenic cells (i.e., oogonia and previtellogenic and vitellogenic oocytes; Martín, 1986). Even though vitellogenic oocytes exhibit ultrastructural indications of active protein synthesis and endocytosis of tubular fluid (Winik \& Castro-Vazquez, 2015), they never attain the massive accumulation of 
TABLE 2. Presence or absence of penial sheath glands in some ampullariid species, and proposed equivalence of names by various authors. The works of Sachawatkin (1920), Hägler (1925), Prashad (1925c), Hylton Scott (1958) and Andrews (1964) are not included, because they referred to these glands collectively as "sheath glands", "superficial glands" or "marginal glands.

\begin{tabular}{|c|c|c|c|c|}
\hline Gland & I & II & III & IV \\
\hline Pila globosa (Swainson, 1822) & outer 1 & absent 1 & absent 1 & distal 1 \\
\hline Marisa cornuarietis (Linnaeus, 1758) & $\begin{array}{c}\text { outer }^{1} \\
\text { gland } 34\end{array}$ & absent 1,4 & $\begin{array}{l}\text { proximal }{ }^{1} \\
\text { gland } 2^{4}\end{array}$ & $\begin{array}{l}\text { distal } 1 \\
\text { gland } 14\end{array}$ \\
\hline Pomacea canaliculata (Lamarck, 1822) & $\begin{array}{c}\text { outer } 1,2 \\
\text { ventral basal }\end{array}$ & absent $1,2,7$ & $\begin{array}{l}\text { proximal }^{1,2}, \\
\text { medial }^{3}\end{array}$ & $\begin{array}{l}\text { distal1,2 } \\
\text { apical } 7\end{array}$ \\
\hline Pomacea maculata Perry, 1810 & ventral basal 3 & basal3 & absent $^{3}$ & apical ${ }^{3}$ \\
\hline Pomacea figulina (Spix in Wagner, 1827)a & basal outer 5 & absent 5 & inner median 5 & apical5 \\
\hline Pomacea sordida (Swainson, 1823) & basal outer 6 & absent 6 & inner median 6 & apical6 \\
\hline Pomacea urceus (Müller, 1774) & outer 1 & absent 1 & proximal 1 & distal 1 \\
\hline
\end{tabular}

1Berthold (1989), ${ }^{2}$ Giraud-Billoud et al. (2013a), 3Hayes et al. (2012), ${ }^{4}$ Schulte-Oehlmann et al. (1994), ${ }^{5}$ Thiengo (1987), 6Thiengo (1989), ${ }^{7}$ Thiengo et al. (1993), amisidentified as Pomacea lineata by Thiengo (1987).

vitelline material observed in other caenogastropods (e.g., Cledón et al., 2005; Averbuj et al., 2010). This difference may be explained by the observation of periodic oocyte formation and gonadal evacuation in those studies but that occur continuously during the breeding season in P. canaliculata (Albrecht et al., 1996). Another correlate of the meager provisioning of oocytes is that developing embryos must rely mostly on perivitelline fluid for nutrition (Heras et al., 1998) (see Egg Proteins: Structure and Role in Defense).

\section{Female Tract}

The visceral oviduct ("renal" oviduct of many authors, at least in part) derives from the visceral section of primordial gonoduct and is homologous with the vas deferens in males (Gamarra Luques et al., 2013). It is also a slender tube, lined by a ciliated epithelium, that runs along the columellar axis to join the seminal receptacle, which is a complex structure at least in Marisa (Schulte-Oehlmann et al., 1994) and Pomacea (Andrews, 1964; Catalán et al., 2002; Hayes et al., 2012). The seminal receptacle is the site for sperm storage and fertilization (Hylton Scott, 1958; Andrews, 1964), and the sperm stored in the seminal receptacle may remain fertile for up to 140 days after copulation (Estebenet \& Cazzaniga, 1993; Albrecht et al., 1996; Estebenet \& Martín, 2002).

The more distal sections of the female tract of $P$. canaliculata (the albumen and capsule glands) are derivatives of the female pallial gonoduct (Gamarra-Luques et al., 2013) and are referred to collectively as the "pallial oviduct" (Catalán et al., 2002, 2006; Simone, 2004; Hayes et al., 2012) or primarily in the older literature as the "uterus" or "uterine gland" (Blainville, 1822; Sachwatkin, 1920; Hägler, 1923; Hylton Scott, 1958; Catalán de Canelada \& Moreno, 1984; Giraud-Billoud et al., 2013a). The pallial oviduct of Pomacea, with its chambered seminal receptacle, branching albumen gland and coiled capsule gland, all embedded in a spongy mass of parenchymal tissue, is one of the most complex among the caenogastropods. Accordingly, understanding its structure and function is a field of active research and many aspects remain unresolved.

The seminal receptacle and the albumen and capsule gland ducts are connected in series in at least Pila (Keawjam, 1987), Marisa (Schulte-Oehlmann et al., 1994) and Pomacea (Berthold, 1991; Hayes et al., 2012), as in most caenogastropods (e.g., Hyman, 1967; Fretter \& Graham, 1994). Nonetheless, descriptions by several authors (Catalán de Canelada \& Moreno, 1984; Catalán et al., 2002) have suggested that the albumen and capsule glands are not connected in series in Pomacea, requiring that the fertilized oocytes receive a perivitelline quota at the junction of the albumen and capsule ducts in P. canaliculata (Andrews, 1964; Catalán et al., 2002, 2006). However, Hayes et al. (2012) have hypothesized that, like 
other caenogastropods, the fertilized oocytes enter the albumen gland ("albumen gland diverticula" or "albumen duct" of other authors) and traverse its entire periphery via a ciliated tract while being coated with albumen. As in other caenogastropods (Ponder \& Lindberg, 1997; Strong, 2003; Ponder et al., 2008), the bursa copulatrix has been considered as a place to receive sperm during copulation before transferring them into the seminal receptacle (Andrews, 1964; Hayes et al., 2012), although others (Giraud-Billoud et al., 2013a) have hypothesized that the bursa is an organ for sperm resorption and phagocytosis, that is, analogous to the "ingesting glands" of higher caenogastropods (Ponder \& Lindberg, 1997). The structural relationships among these complex ducts still require further research, as do functional aspects, for example whether and how sperm are resorbed and how the egg envelopes are provided.

\section{DEVELOPMENT}

The field of ampullariid development has recently experienced a revival but can be traced back to Semper's (1862) monograph on Pila virescens (as Ampullaria polita). Subsequent work during the 20th century treated a few species but has never been comprehensively reviewed. Future integrated studies of morphology, gene expression and proteomics may shed light on the mechanisms by which aspects of ampullariid development are controlled.

Initial Stages of Development

The eggs of ampullariids are fertilized internally and develop externally in calcareous or non-calcareous eggs, deposited in clutches or in gelatinous masses respectively, on submerged vegetation, rocks or other firm substrates (Hayes et al., 2009a, 2012; Burks et al., 2010; Tiecher et al., 2014). The eggs of some species contain pigmented proteins collectively referred to as perivitellins, the colors of which range from white to vivid pink, orange and green, which play diverse functions in the developing embryo (see Egg Laying under Reproductive Behavior and Egg Proteins, for details; Heras et al., 2007; Dreon et al., 2008, 2013; Hayes et al., 2009a).

Eggs exhibit distinct animal and vegetal poles before the first cleavage in Pila globosa, Pomacea canaliculata and Marisa cornuarietis (see Ranjah, 1942; Hylton Scott, 1934; Demian \& Yousif, 1973a, respectively). Gastrulation is the result of invagination (emboly) in Pila globosa and $P$. canaliculata, but is epibolic in M. cornuarietis according to Ranjah (1942), Hylton Scott (1958) and Demian \& Yousif (1973a), respectively; both of these patterns of gastrulation occur in other caenogastropods (e.g., Hyman, 1967).

Like other gastropods lacking a planktonic larval phase, the prototroch in Pila globosa, $P$. canaliculata and $M$. cornuarietis does not develop into a full velum (Brooks \& McGlone, 1908; Hylton Scott, 1934; Ranjah, 1942; Demian \& Yousif, 1973a, 1975; Koch et al., 2009). The rudiment of the mantle cavity forms at an early stage in Pila globosa according to Ranjah (1942) and in P. canaliculata (see Brooks \& McGlone, 1908; Fernando, 1931; Hylton Scott, 1934; Koch et al., 2009) as an ectodermal depression close to the anus and immediately beneath the pericardial rudiments. It seems to occur later in $M$. cornuarietis according to Demian \& Yousif (1973a). In all cases, the growing shell gland engulfs the primitive mantle cavity and turns to the left and front during anopedal flexure and torsion.

A protein-expression approach has been applied for the first time to the development of a gastropod in a study of $P$. canaliculata eggs at stages when most of the organs are formed (Sun et al., 2010). Of the 125 most abundant proteins, 65 were identified and associated with 11 types of cellular functions or pathways. Of these $65,63 \%$ were related to either metabolism $(11 \%)$, energy $(11 \%)$, protein fate $(29 \%)$ or to proteins with binding functions or cofactor requirements $(12 \%)$.

\section{Cardiac, Respiratory and Renal Organogenesis}

The pericardium (and thus the heart) develops in the mesoderm dorsal to the gut as either a single or a double rudiment (Fernando, 1931; Ranjah, 1942; Demian \& Yousif, 1973b). The ctenidium develops in the mantle cavity, but Demian \& Yousif (1973c) traced it back to an ectodermal thickening on the right, posterior side of the embryo in $M$. cornuarietis. The lung develops later during intracapsular development as an outgrowth of the mantle cavity's roof (between the ctenidium and the osphradium) in Pila globosa, P. canaliculata and M. cornuarietis (Brooks \& McGlone, 1908; Hylton Scott, 1934, 1958; Ranjah, 1942; Demian \& Yousif, 1973c, d; Koch et al., 2009). The lung of Asolene pul- 
chella develops in the same location but only after hatching (Tiecher et al., 2014).

In Pila globosa, P. canaliculata and M. cornuarietis, the rudiment of the post-torsional left kidney develops as an outgrowth of the primitive pericardium and connects with the rudiment of the ureter, which itself is an ectodermal outgrowth of the primitive mantle cavity (Fernando, 1931; Ranjah, 1942; Demian \& Yousif, 1973d). The embryonic kidney and ureter become the posterior and anterior kidney chambers of the adult, respectively. The latter opens to the rear of the mantle cavity and communicates with the posterior kidney through a small opening; the posterior kidney is connected to the pericardium via the reno-pericardial duct.

The gonadal sector of the gonoduct in Pila globosa originates from a thickening of the pericardial cavity (Ranjah, 1942). The embryonic, post-torsional right kidney, which would give rise to the visceral (or renal) sector of the gonoduct, has also been reported in Pila globosa (Ranjah, 1942) and P. maculata [as Ampullaria (Pila) gigas Spix in Wagner, 1827] (Fernando, 1931), but has not been found in P. canaliculata (see Hylton Scott, 1934; Koch et al., 2009) and M. cornuarietis (see Demian \& Yousif, 1973b, d).

\section{Digestive Tract}

The cells lining the archenteron, or primitive gut, are large and yellowish in Pila globosa and M. cornuarietis according to Ranjah (1942) and Demian \& Yousif (1973d), respectively. In $P$. canaliculata, they are colorless until the stomodaeum connects with the archenteron and the perivitelline fluid starts to be ingested (Koch et al., 2009), at which point they become reddish-pink and increase in size (that is, "giant cells"; Koch et al., 2009). Pomacea canaliculata embryos rely heavily on the pink-reddish perivitelline fluid for their nutrition (Heras et al., 1998), rather than the limited amount of yolk invested in the oocytes (Winik \& CastroVazquez, 2015).

As development proceeds, the foregut, midgut and hindgut become clearly differentiated (Hylton Scott, 1934; Ranjah, 1942; Demian \& Yousif, 1973c; Koch et al., 2009). In Pila globosa, $P$. canaliculata and $M$. cornuarietis, the foregut gives rise to the pharyngeal bulb with the radula and to the esophagus with the salivary glands and crop. The midgut gives rise to the three-chambered stomach (vestibule, gizzard, style sac) and the midgut gland. The hindgut gives rise to the intestine. The midgut gland develops as two lobes (anterior and posterior), but even though the anterior lobe is initially larger it disappears with development and only the posterior lobe persists into adulthood (Ranjah, 1942; Demian \& Yousif, 1973a; Koch et al., 2009). The detailed origin and putative functions of the cells lining the midgut lobes and forming the midgut alveoli have been described in varying degrees of detail in M. cornuarietis by Lutfy \& Demian (1967) and Demian \& Yousif (1973a) and in P. canaliculata by Koch et al. (2006, 2009), appearing similar in the two species.

\section{Post-Hatching Reproductive Development}

At hatching, the primordial gonoduct of $P$. canaliculata is formed by interconnected cell cords contained within the posterior wall of the mantle cavity. It takes about ten days (by which time the juveniles have reached $5 \mathrm{~mm}$ in shell height) for these cords to develop into a sexually undifferentiated primordial gonoduct. At about the same time, the primordium of the copulatory apparatus appears near the inner right mantle edge and will develop either into the full copulatory apparatus of adult males or the rudimentary apparatus of adult females (Gamarra-Luques et al., 2013). The occurrence of this copulatory rudiment has also been reported in adult females of other Pomacea species (Thiengo, 1987, 1989; Thiengo et al., 1993) and of $M$. cornuarietis (see SchulteOehlmann et al., 1995), but is not attributed to masculinizing pollutants often associated with this phenomenon in other gastropods. Although sometimes apparently lacking (Liu et al., 2006), this rudimentary copulatory apparatus in females can continue to grow after sexual maturity, even in the absence of masculinizing pollutants (Gamarra-Luques et al., 2013; see Environmental Health and Pollution).

In $P$. canaliculata, the gonad is sexually differentiated in $10 \mathrm{~mm}$ juveniles, but the pallial section of the gonoduct remains undifferentiated and the copulatory rudiment is similar in both sexes. In $15 \mathrm{~mm}$ juveniles (30 days old), the pallial gonoduct has differentiated in both sexes, and includes all the components that will be present in the adults. Copulation takes place once snails reach $20 \mathrm{~mm}$ (40 days old), but no eggs are laid, which may be related to the inability of males to fertilize females (oviposition may be directly related to fertilization as most deposited eggs are fertile in $P$. canaliculata) 
or to the inability of females to provide egg envelopes. The snails appear reproductively mature at $25 \mathrm{~mm}$ as their copulations result in the deposition of fertile eggs, and their anatomical and histological features are those of adults (Gamarra-Luques et al., 2013).

\section{LIFE HISTORY}

\section{Life Cycle and Reproductive Seasonality}

Published estimates of longevity in apple snails range from one to four years in Pomacea spp., three years or more in Marisa cornuarietis and Pila spp., and up to ten years in Lanistes nyassianus Dohrn, 1865 (reviewed by Cowie, 2002).

At the southernmost extreme of its native range, in Argentina, $P$. canaliculata may remain inactive for several months due to low winter temperatures (Seuffert et al., 2010) and usually has three to four annual reproductive periods (Estebenet \& Cazzaniga, 1993; Estebenet \& Martín, 2002; Martín \& Burela, personal observations). A one- to two-year life span, similar to that observed in laboratory populations reared at $25^{\circ} \mathrm{C}$ (Estebenet \& Cazzaniga, 1993; Estebenet \& Martín, 2002; Martín \& Estebenet, 2002), may be expected in warmer, subtropical and tropical areas where winter temperatures are not low enough for the snails to become inactive. In their introduced range of more temperate southern Japan, high winter mortality means that the proportion of snails that survive two summers is low (Yoshida et al., 2009). However, a water temperature of $18^{\circ} \mathrm{C}$ seems to be adequate to trigger reproductive activity in overwintering $P$. canaliculata (Albrecht et al., 1999), and reproductive activity still proceeds if temperature is lowered from $25^{\circ} \mathrm{C}$ to $18^{\circ} \mathrm{C}$ (Albrecht et al., 2005). In Hong Kong, with minimum water temperatures of $16^{\circ} \mathrm{C}$, the recruitment period extends up to ten months (Kwong et al., 2010). Photoperiod is not important for initiating and continuing reproduction, because the shortest winter day length (10 h) for the southernmost populations sufficed, given adequate temperatures (Albrecht et al., 1999, 2005). At the other extreme, P. canaliculata reared since hatching under constant illumination, matured, copulated and laid eggs normally (Estebenet \& Martín, 2002; Martín \& Estebenet, 2002).

Also in temperate Argentina, adult $P$. scalaris and Asolene platae (Maton, 1811) were present throughout the year (although inactive during winter), and egg-laying and recruitment were observed from late spring to late summer (March) (Martín, 1984, 1993).

Whereas reproduction in temperate regions is more thermally regulated, in tropical regions it is much more related to water availability. Adults of the Indian Pila globosa remain dormant, buried in dry mud, for up to eight months during the dry season but begin to copulate and lay eggs as soon as the bottom sediments are covered by water at the start of the rainy season (Bahl, 1928; Raut, 1984). They attain maximum size at four years, but the life span is thought to be longer (Haniffa, 1980). Pomacea urceus, in tropical Venezuela, lives for 2.5-3.5 years and breeds during two to three seasons (Burky, 1974); most females attain maturity in their first year (Lum-Kong \& Kenny, 1989). Adults begin to copulate just before the onset of the dry season, a decrease in water level being necessary for mating and egg-laying to begin (Ramnarine, 2003).

Pomacea paludosa in Florida has a short life span (1-1.5 years) and throughout much of its range, the majority of egg-laying occurs during spring/summer, followed by a post-reproductive die-off (Darby et al., 2003, 2008). In this case, both water temperature and depth are critical to oviposition and hatchling growth. Snails become inactive when temperatures drop below $13^{\circ} \mathrm{C}$ (Stevens et al., 2002), and relatively cool temperatures may delay oviposition in the spring (Hanning, 1979). The spring oviposition peak is associated with the dry season, which often culminates in a dry down (i.e., the water table falls below ground level) during which the snails become inactive (Darby et al., 2002, 2008), but, following summer rains, they reinitiate reproduction (O'Hare, 2010).

Thus, reproduction in ampullariids may occur if water is available and if temperatures are high, as during summer in temperate regions or throughout the year in many tropical and subtropical regions. In seasonally wet/dry tropical and subtropical regions, the reproductive cycle seems to be timed to allow hatchlings to reach a large enough size to survive the dry season, while in temperate regions, reproduction only occurs above a threshold temperature.

\section{Life History Variation}

Inter-population variation in many life history traits of $P$. canaliculata has both a genetic and an ecophenotypic basis. Although snails show dif- 
ferences in size at hatching, maturity and maximum size, often in response to different densities (Tanaka et al., 1999; Yoshida et al., 2009, 2013), such differences disappeared in snails reared under homogeneous laboratory conditions, indicating a strong environmental influence; slightly higher mortality, growth and oviposition rates in laboratory snails from unstable and unproductive habitats were attributable to genetic differences among source populations (Martín \& Estebenet, 2002). The high environmental tolerance of $P$. canaliculata and its successful establishment in new environments may be associated with this high level of ecophenotypic plasticity (Estebenet \& Martín, 2002).

The environmental factors involved are not fully understood. Population density and per capita food availability are probably important (Tanaka et al., 1999; Yoshida et al., 2009, 2013). For $P$. canaliculata, the relationship of food availability with size, age at maturity and reproductive performance differ between males and females (Estebenet \& Martín, 2002; Estoy et al., 2002a, b; Tamburi \& Martín, 2009a, 2011). When food availability is lower than optimum, the reproductive strategy of females is to delay maturation and the onset of reproduction (Estoy et al., 2002b; Tamburi \& Martín, 2009a). With reductions in food availability, the mean number of eggs laid during the first reproductive month decreased, although without a significant decrease in the number of clutches or egg size (Estoy et al., 2002b; Tamburi \& Martín, 2011). The size of $P$. canaliculata eggs does not differ relative to food availability (Albrecht et al., 2005; Tamburi \& Martín, 2011) or among populations (Estebenet \& Cazzaniga, 1993). The survival rates of $P$. canaliculata offspring under starvation actually increase if the mothers are faced with chronic food restrictions (Tamburi \& Martín, 2011).

On the other hand, $P$. canaliculata males mature at the same age irrespective of food availability. Growth rates, and hence maturation sizes, are strongly negatively affected by reduced food availability (Tamburi \& Martín, 2009a), but there is no apparent negative effect on reproductive success (Estoy et al., 2002a; Burela \& Martín, 2011; Tamburi \& Martín, 2011).

In laboratory studies of $P$. canaliculata, mortality rate was not affected by food availability, up to a point. Most snails completed their life cycle with food available $30-100 \%$ of the time (Estoy et al., 2002a) and with 20-100\% of the ad libitum daily consumption (Tamburi \& Martín, 2009a). In addition, male growth rate was not reduced with the onset of copulatory activity, while that of females decreased at the start of reproduction (Tamburi \& Martín, 2009a, 2011). This decrease was also observed in isolated cohorts of $P$. canaliculata females that were not allowed to reproduce (Estebenet \& Cazzaniga, 1998) and is probably caused by the decrease in ingestion rates and food conversion efficiencies as snails grow (Tamburi \& Martín, 2009b).

Food quality may also be important because $P$. canaliculata prefers to consume plant species on which it achieves higher growth rates, and despite its broad food preferences avoids certain plants (Estebenet, 1995; Estebenet \& Martín, 2002; Lach et al., 2000; Morrison \& Hay, 2011a). Therefore, even among highly productive habitats, life history variation in $P$. canaliculata could result from differences in availability of preferred food. Interspecific differences in the nutritional value and chemical and physical defenses of plants are correlated with changes in growth, oviposition and mortality rates (Qiu \& Kwong, 2009).

Life history traits, such as number of eggs, age at maturity in females, size at maturity in males and offspring endurance, are highly plastic and influenced by food availability in the environment. This adjustment to different food availabilities allows other traits (that is, egg laying rate, maturation size in females and maturation age in males) to remain unchanged or conserved, probably because these are subject to the strongest selection pressures (Whitman \& Agrawal, 2009). Pomacea canaliculata exhibits the same sexually dimorphic reproductive patterns and the same combination of canalized and plastic traits between native (Tamburi \& Martín, 2009a, 2011) and introduced (Estoy et al., 2002a, b) populations, indicating that this strategy in the non-native range is neither the product of founder effects nor of anthropogenic selective pressures, but an adaptive strategy evolved in its native environment.

\section{REPRODUCTIVE BEHAVIOR}

\section{Mating}

Mating behaviour has been studied in several ampullariids, mostly in the laboratory but in a few cases in the field (Bahl, 1928; Nono \& Mane, 1931; Demian \& Ibrahim, 1971; Hanning, 1979; Guimarães, 1981a, b; Berthold, 
1989, 1991; Faraco et al., 2002; Heiler et al., 2007; Tiecher et al., 2014), although thoroughly only in Pomacea canaliculata (Andrews, 1964; Albrecht et al., 1996; Burela \& Martín, 2007, $2009,2011,2014)$. All descriptions of copulation agree on a basic pattern. Copulation and sperm transfer occur under water, during which the male's foot adheres to the right side of the body whorl of the female while gripping the rim of her shell with the penis sheath. The penis is guided by the penial sheath to the vaginal opening, and from there it passes along the central channel of the capsule gland towards the proximity of the seminal receptacle (GiraudBilloud et al., 2013a).

There is great inter- and intra-specific variation in length of copulation in apple snails, ranging from an average of $38 \mathrm{~min}$ to as long as $20 \mathrm{~h}$ (Burela \& Martín, 2011). The lengthy copulations may be attributed to the complexity of the male and female reproductive anatomy, to the high fecundity of the females, to the existence of mate guarding behavior, or some combination of these (Burela \& Martín, 2011).

In P. canaliculata, copulation may occur during the day or night, with females able to continue to move about freely. Both males and females mate frequently with different partners (Albrecht et al., 1996; Burela \& Martín, 2011; Liu et al., 2012), and mating can be distinguished into four distinct phases: precourtship, courtship, copulation and post copulation (Burela \& Martín, 2009). The precourtship phase, contact with tentacles, palps, feet or snouts, lasts a few seconds. The courtship phase frequently begins with the male circling the female shell but often ends prior to the copulation phase, with the female swinging her shell to dislodge the male. The insertion of the penis sheath into the mantle during the initiation of the copulation phase frequently elicits swinging and withdrawal-wrestling behavior in the female, interrupting the copulation in many cases (Nono \& Mane, 1931; Hanning, 1979). This rejection indicates a possible underlying mate choice mechanism in females (Burela \& Martín, 2009). Copulation may last $13 \mathrm{~h}$ on average, and can extend up to almost $20 \mathrm{~h}$, with most of this time seemingly devoted to the transfer of eusperm (Burela \& Martín, 2011). During copulation the male often secretes a nuptial gift from the outer basal sheath gland. Females feed on this gift, which is probably a mechanism for enticing females to remain in copula (Burela \& Martín, 2011, 2014). Postcopulation has only been observed in a few cases, and may last as long as $1 \mathrm{~h}$, during which the male remains mounted on the female's shell with its sheath retracted into the mantle, a behavior explained as possible mate guarding (Burela \& Martín, 2011).

\section{Egg Laying}

The majority of species, those in Pomacea and Pila, deposit calcareous eggs out of water. Most Pomacea species lay them well above the water line on stems of emergent plants, trunks of riparian trees, rocks and other hard structures, such as bridge supports, and Pila deposit them on vegetation at the water line or directly on the soil surface at the margin of the water (Hurdle, 1973; Hanning, 1979; Turner, 1996; Cowie, 2002; Hayes et al., 2009a; Burks et al., 2010; Kyle et al., 2013). Some Pila species dig a depression in the mud near the shore in which to deposit their eggs (Bahl, 1928; Cowie, 2002). Pomacea paludosa in Florida exhibits preferences for certain plant species on which to lay its eggs, perhaps related in part to the ability of larger stems to support a mature female (Turner, 1996).

Oviposition usually occurs during the night or early morning, probably to reduce the risk of predation by terrestrial animals and the heat and desiccation stress on females and eggs, which take time to harden (Schnorbach, 1995; Albrecht et al., 1996; Estebenet \& Martín, 2002). Oviposition may last up to several hours and occurs with the right side of the foot forming a longitudinal groove that conducts the eggs from the vagina to the substrate at intervals that depend on species (Bahl, 1928; Bachman, 1960; Andrews, 1964; Hanning, 1979; Albrecht et al., 1996; Estebenet \& Martín, 2003). Among species, the average number of eggs per egg mass is inversely related to egg size (Turner \& McCabe, 1990; Cowie, 2002; Martín \& Estebenet, 2002; Barnes et al., 2008; Burks et al., 2010; Kyle et al., 2013).

Aerial egg laying may have evolved to avoid the predation or cannibalism that submerged egg masses suffer (Turner, 1998; Cowie, 2002; Horn et al., 2008; Saveanu \& Martín, 2014), but it incurs diverse costs. There may also be a cost of producing the calcium coating of the eggs, resulting in a trade off between production of progeny and maternal defense, inasmuch as shells of female $P$. canaliculata tend to be thinner than those of males (see Shell Morphology).

A notable exception among Pomacea species to this normal egg laying strategy is the 
behavior of $P$. urceus, which adopts a strategy apparently unique among ampullariids. These snails bury themselves in the drying mud at the beginning of the dry season to aestivate, prior to which females lay their eggs within their shells, between the aperture and the operculum (Burky et al., 1972; Burky, 1974; Lum-Kong \& Kenny, 1989). Development takes place during the dry season and the females release some of their own body water at intervals to cool themselves and their progeny (Burky et al., 1972), which are very sensitive to desiccation (Ramnarine, 2003). The hatchlings emerge as the wet season begins.

All other species of apple snails for which information is available, that is, in the genera Afropomus, Asolene, Felipponea, Lanistes, Marisa and Saulea, deposit non-calcareous eggs in a gelatinous matrix under water (Hayes et al., 2009a; Thiengo et al., 2011). The process is similar to that described for $P$. canaliculata. Deposition of gelatinous packages of three to four eggs usually occurs during the night or early morning on submerged plant stems or leaves in a process that can last $1-3 \mathrm{~h}$ (M. cornuarietis - Demian \& Ibrahim, 1971; Schulte-Oehlmann et al., 1994; Asolene pulchella - Tiecher et al., 2014).

\section{SEX RATIO, SEX DETERMINATION AND KARYOLOGY}

The sex ratio in wild (introduced) populations of Pomacea canaliculata in Japan is 0.5 overall but highly variable among egg masses (Yusa \& Suzuki, 2003; Yusa, 2004b). Chromosomes have been studied in species of Lanistes, Pila, Pomacea and Marisa and there appear to be no dimorphic sex chromosomes (Table 3),

TABLE 3. Ampullariid chromosomes. Unless otherwise indicated, numbers refer to the haploid complement.

\begin{tabular}{|c|c|c|c|c|c|c|}
\hline \multirow[t]{2}{*}{ Species } & \multirow[t]{2}{*}{$\begin{array}{l}\text { Haploid } \\
\text { number }\end{array}$} & \multicolumn{4}{|c|}{ Chromosome groups 1} & \multirow[t]{2}{*}{ Reference } \\
\hline & & $\mathrm{m}$ & sm & st & $\mathrm{t}$ & \\
\hline $\begin{array}{l}\text { Lanistes bolteniana (Deshayes \& } \\
\text { Milne Edwards, 1838)2 }\end{array}$ & 14 & - & - & - & - & Lutfy \& Demian, 1965 \\
\hline $\begin{array}{l}\text { Lanistes bolteniana (Deshayes \& } \\
\text { Milne Edwards, 1838)2 }\end{array}$ & 13 & 8 & 0 & 2 & 3 & Yaseen et al., 1991 \\
\hline Pila ovata (Olivier, 1804) & 14 & - & - & - & - & Lutfy \& Demian, 1965 \\
\hline Pila virens (Lamarck, 1822) & 14 & - & - & - & - & Choudhury \& Pandit, 1997 \\
\hline Pila globosa (Swainson, 1822) & 14 & 9 & 5 & 0 & 0 & Choudhury \& Pandit, 1997 \\
\hline $\begin{array}{l}\text { Pomacea canaliculata } \\
\text { (Lamarck, 1822) }\end{array}$ & 14 & $\begin{array}{l}20^{*} \\
19^{*}\end{array}$ & $\begin{array}{l}6^{\star} \\
7^{\star *}\end{array}$ & $\begin{array}{l}2^{*} \\
2^{* *}\end{array}$ & $\begin{array}{l}0^{*} \\
0^{* *}\end{array}$ & von Brand et al., 1990 \\
\hline $\begin{array}{l}\text { Pomacea canaliculata } \\
(\text { Lamarck, 1822) }\end{array}$ & 14 & 11 & 3 & 0 & 0 & $\begin{array}{l}\text { Mercado-Laczkó \& Lopretto, } \\
1998\end{array}$ \\
\hline Pomacea sp. 5 & 14 & 9 & 4 & 1 & 0 & Kawano et al., 1990 \\
\hline Pomacea flagellata (Say, 1829) & 13 & 9 & 4 & 0 & 0 & Diupotex-Chong et al., 2007 \\
\hline $\begin{array}{l}\text { Pomacea patula catemacensis } \\
\text { (Baker, 1922) }\end{array}$ & 13 & 9 & 4 & 0 & 0 & Diupotex-Chong et al., 2004 \\
\hline $\begin{array}{l}\text { Marisa cornuarietis } \\
\text { (Linnaeus, 1758) }\end{array}$ & 14 & - & - & - & - & Lutfy \& Demian, 1965 \\
\hline
\end{tabular}

Dashes indicate no information reported.

${ }_{1}$ Abbreviations: $m$, metacentric; sm, submetacentric; st, subtelocentric; t, telocentric.

2Incorrectly referred to as "bolteni".

${ }^{3}$ Animals introduced in Japan. One star indicates the diploid complement in females, two stars that in males.

${ }^{4}$ Animals from the native range (Buenos Aires).

5 Animals from São Paulo, Brasil. 
with the possible exception of $P$. canaliculata (perhaps misidentified P. maculata) (von Brandt et al., 1990). Instead, sex in P. canaliculata is determined by a small number of nuclear genes, inherited from both parents (Yusa, 2006a, 2007a, b).

The haploid complement seems to be $n=14$, with $\mathrm{n}=13$ only reported for $P$. flagellata (Say, 1829) and P. patula catemacensis (Baker, 1922), two taxa from Mexico, and the African Lanistes bolteniana (Deshayes \& Milne Edwards, 1838), though there are conflicting reports for this species (Table 3). Metacentric chromosomes are predominant in all species (8-11 chromosomes/ pairs), followed by submetacentric ones (3-5 chromosomes/pairs, with the exception of the L. bolteniana of Yaseen et al., 1991). Subtelocentric or telocentric chromosomes are absent in most species (Table 3).

With the single exception of $P$. patula catemacensis, in which rather long chromosomes have been observed (Diupotex-Chong et al., 2004, 2007), ampullariid chromosomes are much contracted in metaphase, so that measurement error may explain some of the differences summarized above.

\section{HABITATS AND DETERMINANTS OF DISTRIBUTION}

There is no information concerning the ecological determinants of the distributions of the Neotropical genera Marisa, Asolene and Felipponea, nor a quantitative description of their preferred habitats. Similarly, data on Old World taxa are almost lacking.

\section{Habitats}

Most reports of ampullariid habitats are qualitative descriptions, with only a few quantitative studies (Ichinose et al., 2000; Ito, 2002; Karunaratne et al., 2006; Seuffert \& Martín, 2010, 2013a). Apple snails inhabit a wide variety of habitats, but are generally found in shallow, slow-moving or stagnant waters, including waterbodies that dry seasonally (e.g., Brown, 1994; Turner, 1994, Ichinose et al., 2000; Darby et al., 2002; Karatayev et al., 2009; Burlakova et al., 2010; Kwong et al., 2010). Nearly all Old World taxa have been reported from ditches, creeks, small rivers and streams, lakes, pools, reservoirs, swamps, monsoon canals and areas generally associated with shallow, slowly flowing waters, macrophytes, muddy bottoms and shade (McCullough, 1964; Ndifon \& Ukoli, 1989; Brown, 1994; Omudu \& lyough, 2005; Clements et al., 2006).

A few Old World ampullariids seem adapted to live in flowing waters (Prashad, 1925b; Starmühlner, 1979; Keawjam, 1986; Brown, 1994), and some species of Lanistes can occur to depths of 27-82 m (Louda \& McKaye, 1982; Brown, 1994). Similarly, species of Felipponea and some species of Pomacea inhabit faster flowing waters, including those in the highlands of the northern Andes and rivers associated with rocky substrates (Dall, 1904; Faraco et al., 2002; Scarabino, 2004; Corrao et al., 2006; Hayes, 2009).

Pomacea canaliculata is most often considered a lentic species (Hylton Scott, 1958; Castellanos \& Fernández, 1976) although in its native range it is found in both lotic and lentic environments (Martín et al., 2001; Martínez \& Rojas, 2004; Martín \& De Francesco, 2006; Martello et al., 2006). In both habitat types, it is generally found near the margins, associated with macrophytes, slow currents and shallow depths (Lanzer \& Schafer, 1985; Ichinose et al., 2000; Kwong et al., 2010; Maltchik et al., 2010; Seuffert \& Martín, 2010, 2013a). Although $P$. canaliculata is not commonly found in fast flowing environments, it is able to resist current velocities that are among the highest recorded in streams in the Argentinian Pampas (1.61 m.s-1; Seuffert \& Martín, 2012, 2013a).

Pomacea species are more abundant in the shallow marginal areas rich in vegetation in diverse habitat types (Guimarães, 1981b; Karatayev et al., 2009; Burks et al., 2010; Burlakova et al., 2010; Pomacea Project, 2013). They require emergent surfaces including plants for laying eggs above the waterline and, in some cases, for climbing to the water's surface for respiration (Turner, 1996), and prefer marshes with low to moderate density of emergent plant stems over lily-pad dominated habitats (Karunaratne et al., 2006). In some cases, species of Pomacea exhibit preferences for specific vegetation types (Bryan, 1990; Kyle et al., 2011). For example, in the Everglades of Florida, the greatest concentrations of egg clutches occur along the ecotone created by sawgrass and wet prairie or slough habitat (Darby et al., 1999). For all these species, the association with microhabitats close to the margins or with emergent vegetation is probably due not only to availability of adequate substrates for oviposition but also to a combination of factors including predator avoidance, 
food availability and the need for frequent lung ventilation (Seuffert \& Martín, 2010).

\section{Determinants of Distribution}

In general, ampullariids are typically regarded as freshwater snails that do not live in brackish waters (Lanzer \& Schafer, 1985; Cowie, 2002; Hamli et al., 2013). Factors determining the distribution of $P$. canaliculata across different waterbodies have been investigated both in its native range (Southern Pampas; Martín et al., 2001; Seuffert \& Martín, 2013a) and in a nonnative region (Hong Kong; Kwong et al., 2008). These two regions have contrasting climates and topographies, semi-arid to arid plains and subtropical humid hilly terrains, respectively. These studies indicate that $P$. canaliculata distributions are determined by a combination of physicochemical (salinity, alkalinity) and geographic (mountains) barriers in conjunction with stochastic patterns of extinction-colonization events related to local variability of climatic and hydrological conditions (Martín et al., 2001; Martín \& De Francesco, 2006; Seuffert \& Martín, 2013a). However, in the non-native range this species can be found in sub-optimal habitats, indicating that it can at least survive in these habitats for a period of time (Kwong et al., 2008).

Low calcium availability and low pH $(<6.5)$ limit the growth of $P$. paludosa in Florida and lead to thinner, more eroded and more fragile shells (Glass \& Darby, 2009), probably restricting its distribution (Hurdle, 1973; Glass \& Darby, 2009). In the southeastern USA, the models of Byers et al. (2013) show that a pH of $<5.5$ probably precludes invasion by $P$. maculata. Nevertheless, in Cuba, $P$. paludosa seems to be more tolerant than pulmonates of the acidic waters in most reservoirs as it is the only snail present, although in none of them is the $\mathrm{pH}$ less than 6.0 (Perera \& Yong, 1984). In Nigeria, the abundance of Lanistes libycus (Morelet, 1849) shows no significant correlation with any physicochemical variable (Owojori et al., 2006).

Temperature limits the range of many ampullariids as it is a key determinant of their activity thresholds (Stevens et al., 2002; Heiler et al., 2008; Seuffert et al., 2010), growth (Estebenet \& Cazzaniga, 1992; Seuffert \& Martín, 2013b), reproduction (Estebenet \& Martín, 2002; Albrecht et al., 1999, 2005), development (Seuffert et al., 2012) and survival (Matsukura \& Wada, 2007; Wada \& Matsukura, 2007; Mat- sukura et al., 2009a; Seuffert \& Martín, 2013b). Temperature has therefore been used, among other climatic factors, to predict the potential spread of both $P$. canaliculata (Baker, 1998; Zhou et al., 2003; Kwong et al., 2008; Lv et al., 2009a, 2011; EFSA, 2013) and P. maculata (Byers et al., 2013) in their non-native ranges. Ecological niche modeling, combining such climatic models with developmental rates at different temperatures, could be used to predict the isotherms limiting the expansion of ampullariids to higher latitudes, both in their native and non-native ranges (e.g., Lv et al., 2011). At the southernmost limit of its native range $P$. canaliculata is occasionally exposed to temperatures near $0^{\circ} \mathrm{C}$ (Seuffert et al., 2010). However, it cannot tolerate freezing (Matsukura et al., 2009a), suggesting that the isotherm limiting its southern expansion may be close to its actual southernmost extent $\left(37-38^{\circ} \mathrm{S}\right.$; Martín et al., 2001; Seuffert et al., 2010). The northern limit of $P$. canaliculata, in its nonnative range, is $36^{\circ} \mathrm{N}$ in Japan (Ito, 2002) and around $31^{\circ} \mathrm{N}$ in China (Lv et al., 2011). For $P$. maculata in Europe it is between 40 and $41^{\circ} \mathrm{N}$, in the Ebro Delta in Spain (López et al., 2010; Anonymous, 2011); this may also be the limit for $P$. canaliculata as it may also be present in the Ebro Delta.

\section{AMPHIBIOUSNESS}

Ampullariids are unique among freshwater snails in possessing both a fully functional lung for aerial respiration and a gill for aquatic breathing (Andrews, 1965; Berthold, 1989, 1991). The possession of a lung allows many apple snail species to dwell in habitats with poorly oxygenated waters or that frequently dry out (Darby et al., 2002, 2003, 2008; Yusa et al., 2006b; Seuffert \& Martín, 2009). The long siphon of some species allows ventilation of the lung without the snail completely surfacing (Prashad, 1925c; McClary, 1964; Andrews, 1965; Berthold, 1991). Juvenile $P$. canaliculata begin aerial respiration within three hours of hatching, and lung ventilation frequency increases with shell size (Seuffert \& Martín, 2009). In contrast, Burky \& Burky (1977) showed that lung ventilation frequency decreases with body size in $P$. urceus, perhaps related to metabolic depression in the adults during aestivation. The number of pumping movements per lung ventilation increases with snail size in both species (McClary, 1964; 
Burky \& Burky, 1977; Seuffert \& Martín, 2009), probably because of an increase in the volume of the respiratory dead space in the lung and siphon (Seuffert \& Martín, 2009).

While they are primarily aquatic, ampullariids display varying degrees of amphibiousness that range from greater (Asolene, Felipponea, Marisa, Lanistes, and presumably Afropomus and Saulea) to lesser (Pomacea, Pila) reliance on water for the completion of their life cycle (Hayes et al., 2009a). The shift from aquatic to amphibious habits, including aerial oviposition, was probably a key innovation that may have facilitated, at least in part, the diversification and spread of Pila and Pomacea (Hayes et al., 2009a). The cleidoic eggs of most Pomacea species are adapted to exposure to extreme conditions and have developed a physiological dependence on aerial incubation such that they will not develop completely if submerged (Turner, 1998; Pizani et al., 2005; Horn et al., 2008). The deposition of cleidoic eggs above water by Pomacea and Pila and the observation that most Pila virescens die if covered totally by water indicate that they are truly amphibious (Andrews, 1965; Keawjam, 1986; Berthold, 1989, 1991; Cowie, 2002; Hayes, 2009; Hayes et al., 2009a; Seuffert \& Martín, 2010). However, the eggs of some Pila spp. (deposited in pits dug in the ground or at the bases of plants) and $P$. urceus (incubated within the mother's shell) depend on deposition in humid microenvironments, and the embryos are highly susceptible to desiccation (Bahl, 1928; Ramnarine, 2003). In contrast, the other genera, with their gelatinous eggs deposited under water, are linked to aquatic habitats from hatching to maturity (Hayes et al., 2009a).

In Pomacea species, males and females do not differ in lung ventilation frequency nor in oxygen consumption rates (Freiburg \& Hazelwood, 1977; Santos \& Mendes, 1981; Seuffert \& Martín, 2009). However, when access to the water surface for aerial respiration was restricted, females of $P$. canaliculata died or became comatose more frequently than males, which may be a consequence of decreased efficiency of water flow over the gill in females due to the bulging of the albumen gland into the mantle cavity (Seuffert \& Martín, 2010). $A$ reduced lung and a more aquatic mode of life with no air breathing has been suggested for species of Lanistes that occur at deeper depths (Berthold, 1990). However, Bandel (1998) reported that these snails always had air in the lung, even when found $500 \mathrm{~m}$ from the shoreline and $6 \mathrm{~m}$ deep, apparently a result of their ability to capture air bubbles released by aquatic vegetation in the mantle cavity.

\section{DORMANCY}

The fluctuating and highly variable habitats of many ampullariids have influenced the evolution of many aspects of their behavior and physiology, including those underlying aestivation, hibernation and seasonal reproduction. These processes may be entrained by largely predictable changes (e.g., annual changes in photoperiod and mean temperature) but also to less predictable changes (e.g., occasional temperature fluctuations, droughts, rains or floods).

Many ampullariids become dormant in response to drought and/or cold temperatures (d'Orbigny, 1847; Lal \& Saxena, 1952; Meenakshi, 1956, 1964; Oya et al., 1987; Yusa et al., 2006b; Seuffert et al., 2010). Although aestivation is most commonly thought of as a response to high temperatures, it is here defined as when dormancy is induced by lack of water caused by natural or anthropogenic lowering of the water below ground level (e.g., Lal \& Saxena, 1952; Little, 1968; Watanabe et al., 2000). Defined as such, aestivation may occur in either winter or summer (e.g., d'Orbigny, 1847; Wada \& Matsukura, 2007). Hibernation in ampullariids is here defined as dormancy when the ambient temperature becomes low. However, the snails do not enter a deep lethargic state that persists during the entire cold season but show a rather quick response to instantaneous temperature changes, being able to reactivate as soon as conditions are favorable (Seuffert et al., 2010).

Burrowing and closing the shell with the operculum are common apple snail behaviors associated with dormancy. Closing the operculum during dormancy may minimize exposure to the environment, conserve body water (during aestivation) and protect the snail from predators (Meenakshi, 1956, 1957; Coles, 1968; Stevens et al., 2002; Seuffert et al., 2010). Burrowing may occur at the onset of either aestivation or hibernation and may vary diurnally during summer, with maxima around noon and minima around midnight (Oya et al., 1987; Wada \& Yoshida, 2000). High water temperatures $\left(35-40^{\circ} \mathrm{C}\right)$ increased adult male burrowing behavior, but had no effect on females and juveniles. Lower temperatures $\left(<10^{\circ} \mathrm{C}\right)$ led to 
increased proportions of snails buried (Wada \& Yoshida, 2000; Stevens et al., 2002).

\section{Aestivation}

Ampullariids can tolerate prolonged drying of their shallow freshwater habitats (Lal \& Saxena, 1952; Meenakshi, 1956, 1964; Little, 1968; Wada \& Yoshida, 2000; Yusa et al., 2006b), and dormancy seems to be a contingent event precipitated by the dry down of their habitats. Although some species switch to anaerobic respiration at some stage during dry-down events, the capacity for aerial gas exchange is particularly significant during such events, when the snails burrow in the mud (Meenakshi, 1956, 1964; Burky et al., 1972; Thomas \& Agard, 1992). The behavior displayed during experimental induction of aestivation and arousal from it are similar in $P$. lineata and $P$. canaliculata, but the process of entering aestivation takes 2-4 times longer in $P$. lineata (Little, 1968; Giraud-Billoud et al., 2011). Only in $P$. urceus is this dry dormancy thought to be an obligatory part of the life cycle, as drying conditions are a cue for the onset of reproduction (Ramnarine, 2003; see Life History).

Mortality during aestivation in Pomacea species may be affected by duration, water conditions and body size (Little, 1968; Burky et al., 1972; Fan et al., 2000; Darby et al., 2003; Giraud-Billoud et al., 2011). Species differences seem particularly evident in mortality as a function of aestivation duration, but detailed comparisons are difficult, because most reports are of extreme survival times rather than changes in mortality rate over time (Cowie, 2002; Giraud-Billoud et al., 2011). Percent body mass loss during aestivation may be critical for survival. In $P$. canaliculata, a $\sim 50 \%$ loss of body mass was accompanied by a relatively low mortality rate and appeared mostly related to water loss (Giraud-Billoud et al., 2011). Mortality rates were similar in both laboratory and semi-field conditions (Yusa et al., 2006b; Giraud-Billoud et al., 2011). A similar figure for body mass loss was reported for $P$. lineata by Little (1968), but Meenakshi (1964) reported only a $5 \%$ loss in Pila globosa.

Water loss may be limited by rising solute concentrations and hence the osmolality of body fluids. Urea and both uric and lactic acids are accumulated during water deprivation in several ampullariids (see Giraud-Billoud et al., 2011, for references) and may help to retain water, as in other gastropods (Withers et al., 1996). However, the actual increase in osmolality during aestivation in $P$. lineata was lower than expected on the basis of water loss alone (Little, 1968). In fact, deposition of uric acid in urate tissues may reduce osmolality by removing this purine from circulation (GiraudBilloud et al., 2011).

Reduction in metabolic rate is also important for long-term survival during aestivation and/or hibernation because the greater the reduction in metabolic rate, the longer a fixed nutritional reserve can sustain basal metabolism (Storey, 2002). Reduction of oxygen consumption (Burky et al., 1972) and eventual shifting to anaerobic metabolism (in some species) may thus occur during aestivation. Both Pila globosa and $P$. urceus accumulate lactic acid during aestivation, according to Meenakshi (1956) and Burky et al. (1972), respectively, indicating such a shift.

A physiologically significant challenge that limits survival after dormancy is tissue reoxygenation during arousal (Hermes-Lima et al., 1998), which is more sudden after aestivation (and hence, more challenging) than after hibernation. The damaging effects of tissue reoxygenation may be worse than those of the preceding hypoxia (Hermes-Lima et al., 1998). Pulmonates have evolved a variety of enzymatic mechanisms that allow them to endure oxyradical production during tissue reoxygenation (Hermes-Lima et al., 1998; Hermes-Lima \& Zenteno-Savin, 2002; RamosVasconcelos et al., 2005), and recently enzymatic and non-enzymatic antioxidant defense mechanisms have been characterized during the activity-aestivation cyle in $P$. canaliculata (Giraud-Billoud et al., 2011, 2013b). Nothing else is known of the process of reoxygenation following dormancy in ampullariids, and this is an area where additional ecophysiological research may provide crucial insights.

In $P$. canaliculata there is an array of tissues containing intracellular urate crystalloids, which exhibit a sequential process of formation and lysis, suggesting active turnover of uric acid (Giraud-Billoud et al., 2008). Urate tissues begin to differentiate several days before hatching (Koch et al., 2009). Although such tissues have not been reported in other ampullariids, uric acid accumulates during aestivation in both Pila globosa and Pila virens (Lamarck, 1822) (Meenakshi, 1964; Reddy et al., 1974; Chaturvedi \& Agarwal, 1981). Uric acid concentration increases in soft tissues of $P$. canaliculata during aestivation, and drops after arousal. 
Also the concentration of allantoin, a urate oxidation product, increases in kidney and foot tissue after arousal, indicating that uric acid is used as a significant antioxidant defense in the activity-aestivation cycle (Giraud-Billoud et al., 2011, 2013b). Reduced glutathione also seems to participate as an antioxidant in the activityaestivation cycle. Furthermore, changes in the expression of molecular chaperones (Hsc 70, Hsp 70s, Hsp 90) indicate they may participate in protecting the proteome during aestivation and arousal (Giraud-Billoud et al., 2013b).

Sun et al. (2013) quantified and compared 701 proteins isolated from $P$. canaliculata during the activity-aestivation cycle, revealing 53 proteins that were differentially regulated during the cycle. Proteins known to be critical for translation, duplication and energy production were all down-regulated during aestivation, probably because the snails need to conserve resources during aestivation and therefore become hypometabolic. Likewise, hydrocarbon digesting enzymes were down-regulated. Proteins related to lipid metabolism were upregulated, which is consistent with the use of lipids as an energy source during fasting. In the context of enzymatic and non-enzymatic protection against oxidative damage, catalase and a small heat shock protein (sHsp) were up-regulated during aestivation (Sun et al., 2013). Also, two proteins participating in uric acid synthesis were up-regulated, which is in agreement with the central role of this purine as an antioxidant during the activity-aestivation cycle (Giraud-Billoud et al., 2011, 2013b).

The accumulation of uric acid in both active and aestivating ampullariids may also serve other functions (Athawale \& Reddy, 2002; Vega et al., 2007; Giraud-Billoud et al., 2011). Ampullariids may be confronted with drastic environmental changes during which the availability and demand for combined nitrogen may change, and a nitrogen store in the form of uric acid may be adaptive. The reuse of nitrogen contained in uric acid requires its oxidation to allantoin, and then conversion to smaller molecules that can enter the pathways for amino acid and nucleic acid synthesis (Nelson \& Cox, 2004). Uric acid oxidation may occur non-enzymatically (acting as an oxyradical scavenger) or may be catalyzed by urate oxidase. Urate oxidase activity has been found in the midgut gland, foot, lung and gut of $P$. canaliculata (Giraud-Billoud et al., 2011) and in several symbiotic gut bacteria (Koch et al., 2014). However, the incorporation of uric acid nitrogen into protein and nucleic acids has not been demonstrated directly in ampullariids.

\section{Hibernation and Cold Hardiness}

Hibernation in ampullariids has not received as much attention as aestivation, perhaps because most ampullariid species live in tropical or subtropical regions. However, P. canaliculata occurs widely in temperate zones of Argentina, as far south as $38^{\circ} \mathrm{S}$ (Albrecht, 1998; Martín et al., 2001), and invasive populations in Japan also reach similar latitudes (approx. $36^{\circ} \mathrm{N}$ ), withstanding cold temperatures and freezing conditions (Oya et al., 1987; Ito, 2002).

During the coldest months in temperate climates, the snails hibernate lying on the bottom or burying in the mud (Seuffert et al., 2010), but the physiological changes during the activity-hibernation cycle have not been studied. Instead, recent work on P. canaliculata has been focused on the related subject of cold hardiness. In invaded areas of temperate Japan, snails increase their cold tolerance before the onset of winter (Wada \& Matsukura, 2007; Matsukura et al., 2008). The gradually decreasing temperature in autumn is the main environmental cue to enhance cold tolerance (Matsukura \& Wada, 2007). Dry conditions enhance cold tolerance, but photoperiod has no clear effect. After winter, cold tolerance of overwintered snails decreases (Matsukura et al., 2009b).

Cold-tolerant snails in winter accumulate glycerol and possibly glucose in their bodies while glycogen concentration decreases (Matsukura et al., 2008). Among other low-molecular-weight compounds, glutamine and carnosine concentrations increased while phenylalanine decreased. These compunds may be acting as cryoprotectants, as they do in insects (Lee, 1991; Storey \& Storey, 1997), preventing protein denaturation and membrane damage (Michaud et al., 2008; Sjursen \& Somme, 2000). However, glycerol concentration in the snails was much lower than in many insects, and no differences in supercooling points were observed in snails with or without cold tolerance (Lee, 1991; Matsukura et al., 2008, 2009a).

Death of $P$. canaliculata may occur at temperatures as high as $10^{\circ} \mathrm{C}$, well above the temperature (ca. $-7^{\circ} \mathrm{C}$ ) at which the snails freeze (Wada \& Matsukura, 2007; Matsukura \& Wada, 2007; Matsukura et al., 2009b). The mechanism of lethal injury by chilling in the absence of freezing is not well understood, and so 
the actual function of glycerol in $P$. canaliculata is unknown.

Cold tolerance appears to have evolved in ampullariids well before they became invasive species (Seuffert et al., 2010), as populations of $P$. canaliculata established in the Philippines have never experienced cold temperatures in the three decades since their introduction, yet individuals are able to enhance their cold tolerance (Wada \& Matsukura, 2011). Similar responses are noted with snails from northern Argentina (Yoshida et al., 2014). Pomacea canaliculata may not have successfully colonized these temperate areas without some ability to adapt to cold conditions (Ito, 2002; Yoshida et al., 2009), and juveniles of $P$. canaliculata are more tolerant to both cold and desiccation than those of $P$. maculata (Yoshida et al., 2014). (Unfortunately, the specimens identified by Yoshida et al. (2014) as P. maculata are almost certainly a much more narrowly distributed species, which would lead to considerably different interpretations of their data; Hayes, unpublished.). Linkage of cold tolerance with desiccation tolerance is found in both temperate and tropical snails: cold-tolerant snails survive longer after desiccation exposure than coldintolerant snails (Wada \& Matsukura, 2011). There are often similarities in the mechanisms underlying adaptation to cold and desiccation, notably accumulation of metabolites including polyols and sugars, and adjustments of water content and habitat choice (Ring \& Danks, 1994; Michaud et al., 2008). Because the most important abiotic stress on snails in the tropics seems to be drought, this linkage may contribute to retention of the ability to adapt to cold.

\section{FOOD, FEEDING AND DIGESTION}

Feeding has been a major focus of recent ampullariid research. In contrast to the majority of freshwater caenogastropods, which tend to be phytophagous, omnivorous or deposit feeders (Dillon, 2000; Strong et al., 2008), many ampullariids are generalists and capable of feeding on a variety of items such as biofilms, periphyton, floating, submerged and emergent macrophytes, living animals and animal carrion (Cowie, 2002).

\section{Phytophagy and Preferences}

Macrophytes, periphyton and plant detritus are the main food items for ampullariids (Fell- erhoff, 2002; Shuford et al., 2005; Kwong et al., 2010). Some species can detect macrophytes from a distance (Estebenet, 1995). While they generally are not known as major pests in their native ranges (Cazzaniga, 2006), P. maculata and $P$. canaliculata cause major damage to wetland agriculture, notably to rice, taro and semiaquatic vegetables, in their invaded ranges (Joshi \& Sebastian, 2006). Pomacea species also have direct grazing effects on macrophytes in non-agricultural wetlands (Carlsson \& Lacoursière, 2005; Burlakova et al., 2009; Wong et al., 2009; Fang et al., 2010) and indirect effects on wetland water quality and ecosystem processes (Carlsson et al., 2004a).

Given the substantial impact of grazing by Pomacea species on macrophyte diversity and ecosystem processes, several laboratory studies have examined their feeding on macrophytes: $P$. canaliculata in Argentina (Estebenet, 1995), Hawaii (Lach et al., 2000) and Hong Kong (Qiu \& Kwong, 2009; Fang et al., 2010; Wong et al., 2010), and P. maculata in the U.S.A. in Georgia (Morrison \& Hay, 2011a), Texas (Boland et al., 2008; Burlakova et al., 2009; Burks et al., 2011) and Florida (Baker et al., 2010). These studies show that although these species will feed on a diversity of plant species, they do exhibit preferences among them. Snails feeding on their preferred macrophyte species exhibit higher growth rates than snails that have access only to unpalatable food; these snails feed very little, have a low survivorship and grow little.

Other species seem to prefer periphyton, metaphyton (floating mats of detached benthic algae) or floating algae (Rich, 1990; Browder et al., 1994; Sharfstein \& Steinman, 2001; Shuford et al., 2005; Morrison \& Hay, 2011a). Some species are capable of feeding by pedal surface collecting (McClary, 1964; Cazzaniga \& Estebenet, 1984; Saveanu \& Martín, 2013), in which particles on the water surface are collected by ciliary action of the foot sole and periodically ingested. Periphyton is a major food source of $P$. paludosa but vascular plant material may also be important (Rich, 1990) and this species feeds readily on Chara sp. (muskgrass) and Najas marina (spiny naiad) in the field (Hurdle, 1973).

Food preference in herbivores is affected by several characteristics of the plants (Lodge, 1991). Physical defenses include external and internal structures that deter grazing (e.g., spines, hairs, tough leaves, cellulose, lignin). Studies of physical defenses against grazing 
by ampullariids have used toughness (Qiu \& Kwong, 2009) and dry matter content (DMC), with snail feeding rate in both $P$. canaliculata and $P$. maculata negatively correlated with DMC (Burlakova et al., 2009; Wong et al., 2010).

Plant secondary metabolites (e.g., phenolics, alkaloids, terpenes, wax) that are toxic or that interfere with digestion affect food preference in generalist herbivores (Lodge, 1991; Burks et al., 2006). The leaves of Myriophyllum spp. contain high levels of phenolic compounds (Burks \& Lodge, 2002). Incorporating an extract of Myriophyllum spp. into reconstituted but otherwise palatable food reduces the feeding rate of $P$. canaliculata and $P$. maculata, and, when fed on Myriophyllum aquaticum alone, $P$. canaliculata do not grow or reproduce (Boland et al., 2008; Qiu \& Kwong, 2009; Wong et al., 2010). Non-phenolic secondary plant metabolites may also be involved in defense against ampullariids. For instance, Alternanthera philoxeroides containing low phenolic content and a medium level of DMC was not palatable to $P$. canaliculata, and an $A$. philoxeroides extract greatly reduced its feeding rate (Wong et al., 2010). Pomacea canaliculata will use both fresh and decaying macrophyte leaves as long as they contain adequate levels of nutrients and low levels of phenolics (Qiu et al., 2011). Ampullariid grazing can also induce the production of unidentified defense chemicals (Morrison \& Hay, 2011b).

Preferences also reflect the nutritional value of the plants, with snails preferring to feed on plants with higher nitrogen, phosphorous and chlorophyll content than those that are more easily digested but with lower amounts of nutritionally important compounds (Grantham et al., 1993; Sharfstein \& Steinman, 2001; Wong et al., 2010). Similarly, growth rate and egg production were positively correlated with phosphorus and nitrogen content, respectively (Qiu \& Kwong, 2009).

Intraspecific Variation in Feeding and Assimilation

Specific ingestion rates (weight:weight) decrease inversely with snail size (Haniffa \& Pandian, 1974; Haniffa, 1980; Boland et al., 2008; Burlakova et al., 2009; Tamburi \& Martín, 2009a). This has been related to an allometric decrease in the gut cross-sectional area relative to the biomass that must be nourished as body size increases (Tamburi \& Martín, 2009b) and is probably coupled to an ontogenetic decrease in metabolic rate. Similarly, gender differences in ecophysiological performance can be substantial in some species. For instance, the specific ingestion rate in $P$. canaliculata is $50 \%$ higher in females than males of the same size (Tamburi \& Martín, 2009a), perhaps related to the smaller mid-gut gland of males (61-72\% the size of that of females) (Koch et al., 2006), which may restrict the amount of food that can be processed per unit time. Growth rates in male $P$. canaliculata are lower than in females, probably also as a consequence of their smaller mid-gut glands, which in turn results in lower food assimilation (Tamburi \& Martín, 2009b). These findings, in combination with a tendency to mature later (Tamburi \& Martín, 2009b), may explain the common pattern of females growing to be larger than males (Estebenet \& Martín, 2002, 2003; Estebenet et al., 2006). This size difference was also seen in $M$. cornuarietis by Demian \& Ibrahim (1972), P. urceus by Burky (1974) and Lum-Kong \& Kenny (1989), $P$. paludosa by Hanning (1979) and Pila spp. by Keawjam (1987), although the possibility of different ingestion rates or growth efficiencies has not been investigated in these species.

In $P$. canaliculata some studies have shown that young snails are microphagous, changing to macrophytophagy when reaching 15 $\mathrm{mm}$ shell height (Halwart, 1994; Schnorbach, 1995). However, Carlsson \& Brönmark (2006) found no ontogenetic changes in diet in this species, although they did indicate that small snails had higher specific grazing rates, interpreted as higher competitive abilities. Also, hatchlings will survive and grow when fed only fresh vascular plants in the laboratory (e.g., Estebenet \& Cazzaniga, 1992, 1998; Estebenet, 1995; Tamburi \& Martín, 2009b; Qiu \& Kwong, 2009). Furthermore, the relative preference for different macrophytic plants does not change with age (Estebenet, 1995), although large and small snails may feed on different parts of the same plant (Carlsson \& Brönmark, 2006). In Pila globosa, the relative weight of the radula is inversely related to body weight, which was suggested as the cause of declining feeding rates as the snails grow (Haniffa \& Pandian, 1974).

\section{Feeding on Other Animals}

Some ampullariids will prey on the eggs, juveniles and adults of various other snail species (Demian \& Lutfy, 1965a, b, 1966; Cedeño-León 
\& Thomas, 1983; Cazzaniga, 1990; Aditya \& Raut, 2002; Anto et al., 2005; Wong et al., 2009). For this reason, they have been proposed as biocontrol agents against other snail species that are intermediate hosts of human parasites (e.g., Pointier et al., 1988, 1991) as well as against invasive plants, although such approaches can have serious non-target impacts and have been criticized (Cowie, 2001). In Asia, the invasion of $P$. canaliculata may have caused a delay in reproduction and a longer recruitment period in Radix plicatulus (Benson, 1842), perhaps in response to high juvenile mortality from apple snail predation (Lam, 1994). Pomacea canaliculata has also been suggested as causing the decline of Pila species, but whether this occurred through predation or competition remains unclear (Acosta \& Pullin, 1991; Halwart, 1994). Apple snails will even consume conspecific eggs (Horn et al., 2008; Tiecher et al., 2014; Saveanu \& Martín, 2014), hatchlings and juveniles (Yusa et al., 2006a).

Ampullariids may prey on other small animals, such as freshwater oligochaetes (Aditya \& Raut, 2001) and bryozoans (Wood et al., 2005, 2006), as well as eggs of fish (Phillips et al., 2010) and amphibians (Karraker \& Dudgeon, 2014). They will also feed on many kinds of carrion, for example, dead frogs (Cowie \& Hayes, personal observation) and fish (Qiu, personal observation).

It is not known whether some species are capable of detecting their animal prey at distance. However, their large size and a crawling speed that is faster than their prey allow them to search a large area and thus enhance their prey encounter rate; the predation rate varies with the species and life stage of the predator and the size, shape, and shell crushing resistance of the prey (Kwong et al., 2009). Consumption rates vary widely among and within species (Cedeño-León \& Thomas, 1983; Cazzaniga, 1990; Aditya \& Raut, 2002; Anto et al., 2005; Kwong et al., 2009).

\section{Digestion}

Polysaccharides, including cellulose and hemicellulose (the major components of plant cell walls) and starch (a cytoplasmic component), are universally present in the diet of ampullariids. The ability of $P$. canaliculata to digest cellulose (Vega et al., 2006) has recently been confirmed by cloning and expression of two endogenous cellulases (Imjongjirak et al., 2008). Another cellulase produced by an endosymbiotic Bacillus has been reported in a species that is probably also $P$. canaliculata (Zhang et al., 2007). Hemicellulose can be hydrolized by endo-1,4- $\beta$-D-xylanase, which has been purified from soft tissue extracts of $P$. canaliculata (Yamaura et al., 1997), and starch can be hydrolyzed by an amylase found in the midgut gland (Sun et al., 2013). Carbohydrate residues can be released from macromolecules by several enzymes ( $\alpha$-and $\beta$-mannosidase, $\beta$ - $\mathrm{N}$-acetylglucosaminidase, $\beta$-galactosidase and $\alpha$-fucosidase; Hirata et al., 1996, 1998a-c).

Several proteases have been reported in $P$. canaliculata, including one produced by the salivary glands and two in the intestine; one associated with $\mathrm{C}$ and $\mathrm{K}$ morphotypes of an endosymbiont released from midgut gland cells, is ubiquitous in the digestive tract (Godoy et al., 2013) (see Symbiotic Associations).

\section{PREDATORS AND PREDATOR AVOIDANCE}

\section{Predators}

The best-known natural enemies of apple snails throughout much of their natural range in North, South and Central America include limpkins (Aramus guarauna) and snail kites (Rostrhamus sociabilis), for which apple snails are the almost exclusive food source (Snyder \& Snyder, 1969; Snyder \& Kale, 1983; Tanaka et al., 2006; Mapelli \& Kittlein, 2011; Bergmann et al., 2013). Predation presents a strong selective pressure on shell color and shell size of Central American Pomacea flagellata (Reed \& Janzen, 1999), and is likely to have similar effects on other apple snail species, including P. paludosa (Darby et al., 2007; Cattau et al., 2010). In Florida, although the snail kite's natural prey is $P$. paludosa, since the introduction of P. maculata (Rawlings et al., 2007), this non-native species has become a common prey, despite the kites' difficulty in handling the largest individuals (Darby et al., 2007; Cattau et al., 2010; Pomacea Project, 2013).

In their native range, apple snails are also eaten by caimans (Alligatoridae) (Halwart, 1994; Laporta-Ferreira \& Salomão, 2004) caiman lizards (Dracaena spp., Teiidae) (Perera \& Walls, 1996) and a wide range of avian and aquatic predators that target all size classes. These include more generalist avian predators such as boat-tailed grackles (Quiscalus major) and white ibis (Eudocimus albus), aquatic 
predators such as redear sunfish (Lepomis microlophus), turtles (Trionyx ferox, Trachemys scripta elegans, Sternotherus spp., Kinosternon spp.) and alligators (Alligator mississippiensis) (reviewed in Pomacea Project, 2013; Burks, unpubl. dat.).

Yusa (2006b) provided a relatively comprehensive but non-exhaustive list of known predators of invasive apple snails in Asia, including 46 species in 16 orders. This list, together with additional predators noted by other authors indicates apple snails are on the menu for a wide array of insects, crustaceans, fish, reptiles, leeches, birds and mammals (Yusa et al., 2000; Yusa, 2001; Ichinose et al., 2002; Carlsson et al., 2004b; Wong et al., 2009; Sawangproh \& Poonswad, 2010).

The relatively small size of many Pomacea hatchlings (e.g., P. canaliculata shell height $<$ $3 \mathrm{~mm}$; Hayes et al., 2012) and their relatively thin shells allow them to be readily consumed. An additional suite of predators target juvenile apple snails in their native range including crayfish (Procambarus sp.) and aquatic insects (water bugs, Belostoma sp.; dragonfly naiads, Coryphaeschna ingens; and diving beetles, Dytiscus marginalis) (Snyder \& Snyder, 1971). However, in general, apple snails become decreasingly vulnerable to predation with size, and after reaching $20 \mathrm{~mm}$, relatively few predators in the non-native range in Asia can prey on them. The effectiveness of carp, tilapia, ducks and turtles has been evaluated in the field in the context of biological control (Yusa, 2006b; Yoshie \& Yusa, 2008, and references therein). Each of them acts fairly well as a biocontrol agent, although their use may have negative impacts on other aquatic animals and plants (Yoshie \& Yusa, 2008; Wong et al., 2009).

Direct comparisons of predation pressures on native snails and introduced Pomacea have been few, but two species of rats both prefer $P$. canaliculata over native Semisulcospira libertina (Gould, 1859) or Radix quadrasi (Möllendorff, 1898), respectively (Yusa et al., 2000; Joshi et al., 2006). In the laboratory, common carp readily consume $P$. canaliculata while rejecting the thicker-shelled Sinotaia quadrata (Benson, 1842) (Kwong et al., 2009). In Japan, while apple snails rapidly multiply in rice fields and other shallow wetlands with few predators (Yusa, 2006b), predators seem to effectively control their populations in canals, creeks and rivers (Yusa, 2006b; Yusa et al., 2006a) in an apparent example of biotic resistance to an invasive species (Yamanishi et al., 2012).

\section{Predator Avoidance}

In addition to the fact that the largest Pomacea individuals are not readily preyed upon, these species exhibit two major predator avoidance strategies: chemical defenses during the egg/hatchling stages (see Egg Proteins: Structure and Role in Defense) and predator avoidance behaviors.

The presumably aposematic color of Pomacea eggs is due to pigmented proteins that advertise the presence of neurotoxins, antinutrivitve proteins and digestive inhibitors at least in $P$. canaliculata (Heras et al., 2008; Dreon et al., $2010,2013)$. Eggs of various Pomacea species have been reported as being ingested by a few species, including ants, Hemiptera and Orthoptera, but only the fire ant Solenopsis geminata is known to consume them significantly (Yusa, 2001, 2006a). Other observations of birds (Guimarães, 1981b), fish, a frog and a millipede (Snyder \& Snyder, 1971), a land snail (Ng \& Tan, 2011) and turtles (Burks, unpublished) all require additional study to ascertain whether they represented anything more than accidental ingestion or ingestion only under captive experimental conditions. Whether other apple snail eggs deposited above water but lacking pigmentation (i.e., Pila spp.) or laid under water possess such protections is not known.

Ampullariids avoid predators by crawling out of the water, situating themselves near the water surface, burying themselves in the mud, and falling from substrates on which they were crawling (Snyder \& Snyder, 1971; Ichinose, 2002; Ichinose et al., 2003; Carlsson et al., 2004b; Aizaki \& Yusa, 2009, 2010). In P. canaliculata, these behavioral repertoires are size-dependent: hatchlings tend to crawl out of the water; juveniles mainly bury themselves or use near-surface habitats; larger snails are less responsive (Ichinose, 2002). These behaviors are in part innate, but can be learned in some instances when exposed to novel predators (Aizaki \& Yusa, 2010) and may be predator specific (Ueshima \& Yusa, 2014). These diverse strategies have surely played a role in their success in the native range and probably also enhance invasiveness.

\section{EGG PROTEINS: STRUCTURE AND ROLE IN DEFENSE}

The main components of the egg vitellus (lipids, proteins, carbohydrates) are incorporated 
during vitellogenesis into primary oocytes to serve mainly as energetic and structural sources for the developing embryo. Most gastropods, however, contain a limited amount of vitellus, and instead, egg reserves are accumulated surrounding the fertilized oocyte as a perivitelline fluid (De Jong-Brink et al., 1983).

The successful strategy of laying eggs above water results in a variety of selective challenges as the eggs are exposed to stressful environmental conditions that may affect embryonic development and survival of offspring (Przeslawski, 2004). Ampullariids have evolved to handle these challenges through the production of several egg proteins found in the perivitelline fluid, referred to as perivitellins. Although the eggs of many snail species face intense predation pressure, those of $P$. canaliculata have very few predators (Yusa, 2001) (see Predators and Predator Avoidance) because of a suite of chemical defenses provided by the perivitellins. These defenses are advertised by the conspicuous color of the eggs (Heras et al., 2007).

At the biochemical level, the eggs of at least some Pomacea species possess a unique group of perivitellins, which are multifunctional complexes functioning in storage, predator defense and protection from the environment (e.g., Dreon et al., 2008, 2013). In spite of the central role of perivitellins in reproduction and development, there is little information on their structural features in invertebrates. Studies in molluscs are limited essentially to the perivitellins of Pomacea, mostly in $P$. canaliculata but also $P$. scalaris and P. maculata (Ituarte et al., 2012; Pasquevich et al., 2014).

\section{Perivitellin Structure and Synthesis}

Two major perivitellins, now known as PcOvo and PcPV2, have been characterized from the perivitelline fluid of $P$. canaliculata (Cheesman, 1958; Garín et al., 1996; Dreon et al., 2004a, 2010, 2013; Ituarte et al., 2010; Sun et al., 2012b). Both perivitellins are multimeric proteins with remarkabe thermal stability up to $100^{\circ} \mathrm{C}$ and $60^{\circ} \mathrm{C}$, respectively, and over a wide range of $\mathrm{pH}$ (Dreon et al., 2008; Frassa et al., 2010). They are highly resistant to the combined action of pepsin and trypsin proteases, and $\mathrm{PcOvo}$ has proteinase inhibitor activity (Norden, 1972; Dreon et al., 2010).

The perivitelline fluid of $P$. scalaris contains two major perivitellins, of which only the pigmented one, PsSC, which is structurally similar to PcOvo, has been characterized (Ituarte et al., 2008, 2012). The perivitelline fluid of $P$. maculata is also similar, with two major perivitellins, PmPV1 and PmPV2 (Pasquevich et al., 2014). PcOvo, PsSC and PmPV1 act as carriers of antioxidant carotenoid cofactors, notably astaxanthin, which are extremely labile in solution but are not degraded when bound to the perivitellins (Ituarte et al., 2008; Pasquevich et al., 2014). PcOvo and PsSC also carry phosphate groups attached to serine residues that may serve as a phosphorous reserve for the embryo, as do other egg proteins (Ituarte et al., 2010).

Synthesis of PcOvo and PcPV2 occurs in the albumen gland with no circulating perivitellin precursors in the hemolymph (Dreon et al., 2002, 2003). Analysis of the albumen gland transcriptome indicated that other components of the perivitelline fluid, as well as these perivitellins, are also exclusively synthesized in the albumen gland (Sun et al., 2012b). In the parenchymal mass of this gland, albumen secretory cells and labyrinth cells are involved in the synthesis of perivitelline fluid, but only the albumen secretory cells are involved in PcOvo and PcPV2 synthesis, with both proteins packed into the same secretory granules, together with galactogen (Catalán et al., 2006).

\section{Perivitellin Functions}

Analysis of the perivitellin sequences of $P$. canaliculata, based on the Kyoto Encyclopedia of Genes and Genomes (KEGG), classified the 59 sequenced proteins into "unknown" (34), "environmental information processing" (10), "metabolism" (7), "organismal systems" (2), "cellular processes" (3), and "others" (3). Among the "environmental information processing" cluster, nine proteins are related to innate immunity (Sun et al., 2012b). These results indicate that maternal investment in $P$. canaliculata eggs is complex.

In P. canaliculata PcOvo and PcPV2 are storage proteins that provide energetic and structural precursors for the embryos, since they are consumed during development (Heras et al., 1998). The different glycosylation patterns of these two perivitellins probably allow the differential uptake and protein targeting observed during embryogenesis (Heras et al., 1998). In addition, PcOvo carries and stabilizes astaxanthin within the perivitelline fluid and when embryos take up PcOvo (Heras et al., 1998), this potent antioxidant carotenoid can be 
incorporated into their cytoplasmic membranes for protection, while providing the pink-reddish color of the eggs (Dreon et al., 2004b). PcOvo also helps eggs cope with the harsh abovewater conditions. First, the saccharide moiety of PcOvo, together with the high levels of galactogen in the perivitelline fluid (Heras et al., 1998), prevents egg desiccation. Second, the pigmented perivitellins may also protect the embryos against solar radiation, acting as filters (Dreon et al., 2004b).

PcPV2 is a potent neurotoxin (Heras et al., 2008). Each of the four dimeric units of PcPV2 consists of a carbohydrate-binding protein (probably the targeting module) attached to a pore-forming subunit (probably the toxic moiety). Due to their high $\mathrm{pH}$ stability and protease resistance, the dimers are able to reach the intestine while still biologically active and to bind to enterocytes, eventually reaching the circulatory system. PcPV2 is the first proteinaceous egg neurotoxin reported, and bears structural resemblance to botulinic and ricin heterodimeric toxins, the so called "AB toxins" previously only known in bacteria and plants (Dreon et al., 2013). However, as PcPV2 is rather slow-acting (at least in mice) it seems unlikely that it could by itself account for the extremely low levels of predation. Some sort of synergy occurs with PcOvo, which rapidly decreases rat growth when administered orally, probably involving both the inhibition of trypsin activity (antidigestive role) and resistance of the protein to digestion by gut enzymes (antinutritive role), thereby limiting the predator's capacity to digest egg nutrients (Dreon et al., 2010).

PcOvo and PcPV2 are also present in the midgut gland of new $P$. canaliculata hatchlings. In the laboratory, goldfish (Carassina gibelio) will not eat new hatchlings after they sample them (Yusa, personal observations). Similar observations have been made on eggs of $P$. paludosa (Snyder \& Snyder, 1971; Romer, 1972). Also, the albumen gland cytosol of $P$. canaliculata is lethal to mice after intraperitoneal administration (Cadierno, Dreon \& Heras, unpublished). The toxicity seems to be due to the presence of an active PcPV2 neurotoxin as the mice showed similar signs to those exhibited by mice that had been administered purified PcPV2 (Cadierno, Dreon \& Heras, unpublished). It is possible that toxic perivitellins together with still unknown compounds present in the albumen gland of adult Pomacea females may explain why some predators avoid eating the gland while consuming the rest of the body, as for example rats and crows in the non-native range and the snail kite and limpkins in the native range (Yusa et al., 2000; Heras, personal observations; Yusa, personal observations).

In P. scalaris, apart from its assumed nutritive role, PsSC acts as a carotenoid carrier, giving pigmentation to the eggs and supplying the embryos with antioxidant molecules, as does PcOvo (Ituarte et al., 2008). However, unlike $\mathrm{PcOvo}$, this perivitellin is a carbohydrate binding protein, which agglutinates erythrocytes, showing a high specificity for galactosamine and glucosamine containing glycans (Ituarte et al., 2012). Carbohydrate binding proteins may have an immune function, agglutinating bacteria or other pathogens. However, given that PcSC is resistant to $\mathrm{pH}$ changes and gastrointestinal digestion, it may also have an antipredator function; there are multiple examples of a similar function in plants, in which lectins from seeds protect the embryos (Peumans \& Van Damme, 1995). Although P. scalaris eggs do not possess an active PcPV2-like toxin, and the perivitelline fluid seems non-toxic to mice (Ituarte, personal observations), predation on these eggs has not been reported.

\section{Evolutionary and Ecological Implications of Egg Defenses}

Pomacea canaliculata is the first animal known to deter predation with a combination of antinutritive, antidigestive and neurotoxic compounds, a widespread defensive strategy in plants. Among predator avoidance tactics, conspicuous coloration advertises antipredator defense across many taxa. However, $P$. canaliculata eggs are unusual in that $\mathrm{PcO}$ vo not only provides the warning signal but also participates in the biochemical defense. Another unusual aspect is that the defensive molecules are at the same time storage proteins that are later consumed by embryos and hatchlings (Heras et al., 1998), making synthesis particularly cost-effective. Also, as the toxins are proteins, females do not need to ingest toxic prey to endow the eggs with chemical defenses, a common practice in other organisms. The multiple functions of these egg proteins are summarized in Figure 4.

Considering that aerial eggs with conspicuous coloration are frequent across the Ampullariidae, biochemical defenses similar to those of $P$. canaliculata are probably more widespread in the genus, providing a potentially important 


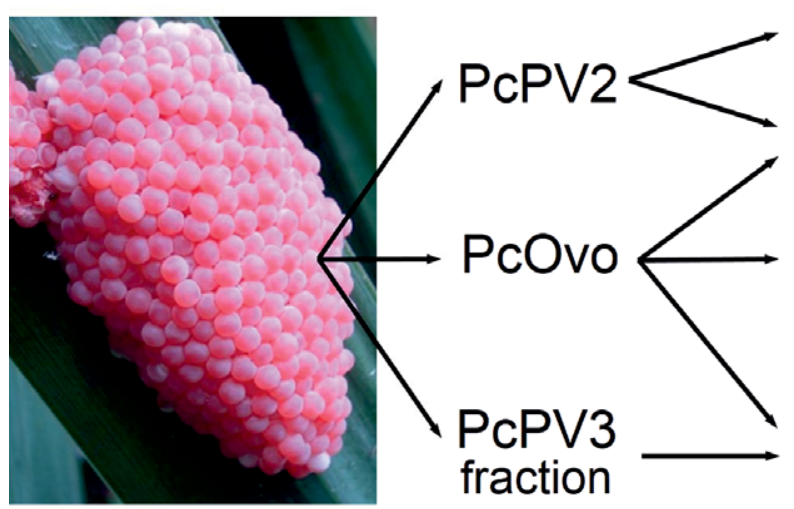

Neurotoxic

Reduce egg digestibility

(Antinutritional)

Proteinase inhibitor

(Antidigestive + protect toxic components)

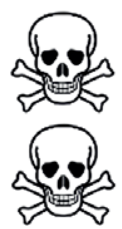

Warning coloration (Aposematic)

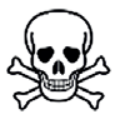

FIG. 4. The multiple roles of egg proteins in Pomacea canaliculata.

model for the study of the evolution of aposematism and defense using perivitellins (Heras et al., 2007; Dreon et al., 2010).

\section{SYMBIOTIC ASSOCIATIONS}

Ampullariids have established an amazing variety of symbiotic associations, but like much of the other information for apple snails, knowledge of these symbioses comes primarily from studies of $P$. canaliculata.

\section{Epibiotic Organisms}

The periostracum of relatively large and slowly moving snails like apple snails provides a potential surface for the attachment of many aquatic organisms. Di Persia \& Radici de Cura (1973) described diverse assemblages of epibionts including filamentous cyanobacteria, chlorophytes and chrysophytes, and sessile ciliates, with a diverse assemblage of motile organisms living within this algal mat, including euglenophytes, ciliates, rotifers, annelids and dipteran larvae. Additional epibionts recorded on apple snails include the colonial sessile peritrich Epistylis plicatilis (Vega et al., 2006; Utz, 2007), the ectoproct Hyalinella vaihiriae (see Cazzaniga, 1988) and naidid oligochaetes in the umbilicus (Gorni \& Alves, 2006).

\section{Endosymbiotic Animals}

Numerous animal taxa have been reported in the mantle cavity, hemocoel or connective tissue as symbionts of various ampullariids
(Table 4). Leeches are the most frequently reported annelids in the mantle cavity. All life stages of Helobdella ampullariae (juveniles, adults and adults with both cocoons and broods) were found inside $P$. canaliculata but never free in the habitat (Damborenea \& Gullo, 1996). The abundance of $H$. ampullariae on $P$. canaliculata increases with host size, with up to 65 in the largest snails. Transmission of the symbiont seems to occur during copulation (Damborenea \& Gullo, 1996). Adult brooders and juveniles of $H$. ampullariae were also found in autumn and winter, while the four other Hirudinea species were only found during the spring and summer (Damborenea \& Gullo, 1996).

Although the two cyclopoid copepods (Table 4) are found in the hemocoel, Ozmana huarpium is more common in the mantle cavity $(63-65 \%$ of mature forms), where it occurs mainly in the ctenidium (in both sexes) and in the penial sheath groove in males. Female $O$. huarpium are more frequent than males in the mantle cavity, and mature females bearing egg sacs seem to be the infecting stage, and to be transmitted by copulation (Gamarra-Luques et al., 2004). Cyclopoid copepods are primarily marine species, but two of the ten recognized families are associated exclusively with freshwater hosts: the Lernaeidae with freshwater fish and the Ozmanidae with ampullariids (Ho, 1994; Boxshall \& Strong, 2006).

Trematodes and nematodes occur in the mantle cavity, hemocoel and connective tissue of various organs or the gut lumen of ampullariids (Table 4; see Human Health Concerns). In addition, Keawjam et al. (1993) reported meta- 
TABLE 4. Animal endosymbionts of Ampullariidae.

\begin{tabular}{|c|c|c|}
\hline Symbiont & Host ampullariid species & References \\
\hline \multicolumn{3}{|l|}{ Turbellaria } \\
\hline Temnocephala iheringi1,2 & $\begin{array}{l}\text { Pomacea canaliculata (Lamarck, 1822) } \\
\text { Pomacea haustrum (Reeve, 1856) } \\
\text { Pomacea lineata (Spix in Wagner, 1827) } \\
\text { Pomacea megastoma (Sowerby, 1825) } \\
\text { Asolene platae (Maton, 1811) }\end{array}$ & $\begin{array}{l}\text { Damborenea, 1996; Dambore- } \\
\text { nea \& Cannon, 2001; Martín } \\
\text { et al., } 2005\end{array}$ \\
\hline T. haswelli & Pomacea canaliculata (Lamarck, 1822) & Seixas et al., 2010a \\
\hline T. rochensis & Pomacea canaliculata (Lamarck, 1822) & Seixas et al., 2010b \\
\hline T. lamothei & Pomacea megastoma (Sowerby, 1825) & Damborenea \& Brusa, 2008 \\
\hline \multicolumn{3}{|l|}{ Hirudinea } \\
\hline Helobdella ampullariae 1 & $\begin{array}{l}\text { Pomacea canaliculata (Lamarck, 1822) } \\
\text { Pomacea megastoma (Sowerby, 1825) } \\
\text { Pomacea maculata Perry, } 1810\end{array}$ & $\begin{array}{l}\text { Ringuelet, 1945, 1985; Dambo- } \\
\text { renea \& Gullo, } 1996\end{array}$ \\
\hline H. triserialis & Pomacea canaliculata (Lamarck, 1822) & Damborenea \& Gullo, 1996 \\
\hline H. simplex & Pomacea canaliculata (Lamarck, 1822) & Damborenea \& Gullo, 1996 \\
\hline H. adiastola & Pomacea canaliculata (Lamarck, 1822) & Damborenea \& Gullo, 1996 \\
\hline Gloiobdella michaelseni & Pomacea canaliculata (Lamarck, 1822) & Damborenea \& Gullo, 1996 \\
\hline \multicolumn{3}{|l|}{ Acari } \\
\hline $\begin{array}{l}\text { Unionicola (Ampullariatax) } \\
\text { ampullariae } 1\end{array}$ & $\begin{array}{l}\text { Pomacea canaliculata (Lamarck, 1822) } \\
\text { Pomacea maculata Perry, } 1810\end{array}$ & $\begin{array}{l}\text { Di Persia \& Radici de Cura, } \\
1973\end{array}$ \\
\hline \multicolumn{3}{|l|}{ Copepoda } \\
\hline Ozmana haemophila 3 & Pomacea maculata Perry, 1810 & Ho \& Thatcher, 1989 \\
\hline O. huarpium 1,3 & Pomacea canaliculata (Lamarck, 1822) & Gamarra-Luques et al., 2004 \\
\hline \multicolumn{3}{|l|}{ Trematoda } \\
\hline Cercaria pomaceae & Pomacea paludosa (Say, 1829) & $\begin{array}{l}\text { Hanning \& Leedom, 1978; } \\
\text { Leedom \& Short, } 1981\end{array}$ \\
\hline Schistosomatidae & $\begin{array}{l}\text { Pomacea canaliculata (Lamarck, 1822) } \\
\text { Pomacea figulina (Spix in Wagner, 1827) } \\
\text { Pomacea lineata (Spix in Wagner, 1827) } \\
\text { Pomacea maculata Perry, } 1810\end{array}$ & $\begin{array}{l}\text { Ostrowski de Nuñez, 1979; Di- } \\
\text { giani \& Ostrowski de Nuñez, } \\
\text { 2000; Damborenea et al., } \\
\text { 2006; Thiengo, unpublished }\end{array}$ \\
\hline Echinostoma spp. & $\begin{array}{l}\text { Pila scutata (Mousson, 1848) } \\
\text { Pila spp. } \\
\text { Pomacea canaliculata (Lamarck, 1822) }\end{array}$ & $\begin{array}{l}\text { Graczyk \& Fried, 1998; } \\
\text { Weerachai et al., } 2011\end{array}$ \\
\hline $\begin{array}{l}\text { Echinostoma } \\
\text { parcespinosum }\end{array}$ & Pomacea canaliculata (Lamarck, 1822) & Martorelli, 1987 \\
\hline Dietziella egregia & Pomacea canaliculata (Lamarck, 1822) & $\begin{array}{l}\text { Digiani \& Ostrowski de Núñez, } \\
2000\end{array}$ \\
\hline Catadiscus pomaceae & Pomacea canaliculata (Lamarck, 1822) & Hamann, 1992 \\
\hline \multicolumn{3}{|l|}{ Rotifera } \\
\hline Bdelloidea & Pomacea canaliculata (Lamarck, 1822) & Vega et al., 2006 \\
\hline \multicolumn{3}{|l|}{ Nematoda } \\
\hline $\begin{array}{l}\text { Angiostrongylus } \\
\text { cantonensis }\end{array}$ & Pomacea canaliculata (Lamarck, 1822) & Lv et al., 2008, 2009a, b, 2011 \\
\hline
\end{tabular}




\begin{tabular}{cl}
\hline Host ampullariid species & \multicolumn{1}{c}{ References } \\
\hline Pomacea lineata (Spix in Wagner, 1827) & Thiengo et al., 2010 \\
Pomacea maculata Perry, 1810 & Teem et al., 2013 \\
Pomacea paludosa (Say, 1829) & Wallace \& Rosen, 1969 \\
Lanistes carinatus (Olivier, 1804) & Ibrahim, 2007 \\
Pila ampullacea (Linnaeus, 1758) & Punyagupta, 1965 \\
Pila virescens (Deshayes, in Bory de & Tesana et al., 2009 \\
Saint Vincent, 1824)5 & \\
Pila pesmei (Morlet, 1889) & Tesana et al., 2009 \\
Pila gracilis (Lea, 1856) & Tesana et al., 2009 \\
Pila scutata (Mousson, 1848) & Tesana et al., 2009 \\
\hline
\end{tabular}

1Detected in mantle cavity.

2Detected in lung.

3 Detected in hemocoel.

4Perhaps incorrectly identified, as P. paludosa is not otherwise known from Hawaii (Cowie et al., 2007).

5Reported as Pila polita, which is an objective junior synonym of $P$. virescens (Cowie \& Héros, 2012).

cercariae of three trematodes (an amphistome, a distome and an echinostome) in introduced $P$. canaliculata in Thailand.

\section{Endosymbiotic Protists and Bacteria}

Among protists, two species of large ciliates have been found in the gut of $P$. canaliculata (Gascón, 1975). Numerous coccoid or rodlike heterotrophic bacteria occur in the gut of ampullariids but almost no attempt has been made to identify them or to explore their functions, such as cellulose digestion (Vega et al., 2005). Several endoglucanases have been isolated from Pomacea "insularus" (probably $P$. canaliculata or perhaps $P$. maculata) (Yamaura \& Matsumoto, 1993; Yamaura et al., 1997; Li et al., 2005), which were probably of bacterial origin. Specifically, a cellulase is secreted by a Bacillus strain (Zhang et al., 2007) (see Digestion), and bacteria in the genera Pseudomonas, Enterobacter, Citrobacter and Lactoccocus degrade uric acid (Koch et al., 2014).

Intracellular Pigmented Corpuscles in the Midgut Gland

At least some ampullariids bear two types of intracellular pigmented corpuscles (named $\mathrm{C}$ and $\mathrm{K}$ corpuscles) in the midgut gland that are eliminated in the feces and for which a symbiotic nature has been proposed. These include the Neotropical Pomacea canaliculata, P. maculata, P. scalaris, Marisa cornuarietis,
Asolene pulchella and A. spixii (d'Orbigny, 1838) (Castro-Vazquez et al., 2002; Vega et al., 2006; Takebayashi, 2013) and the Asian Pila virens (Meenakshi, 1955; Devi et al., 1981) and Pila scutata (Mousson, 1848) (as conica Wood, 1828, a junior synonym of scutata; $\mathrm{Ng}$ et al., 2014) introduced in Hawaii (Takebayashi, 2013).

Among all the symbiotic associations summarized here, this is the only one that appears to be obligate for the host, as the symbionts are present in all individuals of all studied populations (Vega et al., 2006). Both morphotypes together account for $8-11 \%$ of the midgut gland mass (Vega et al., 2005). Because they have a plasma membrane and thick, electron dense wall, but lack a nucleus (Koch et al., 2006), they have been considered as prokaryotes. Even though axenic cultures of these corpuscles have not been obtained (Koch, 2008), morphotype $C$ may persist for at least 3 years in aquarium sediments that had contained fecal droppings of $P$. canaliculata, while morphotype $\mathrm{K}$ tends to disappear with time (Koch et al., 2006).

Morphotypes $\mathrm{C}$ and $\mathrm{K}$ occur respectively in columnar and pyramidal cells of the midgut gland tubular alveoli (Koch et al., 2006). These cells originate in the midgut gland before hatching, before pigmented corpuscles can be recognized, and have been described in both Marisa cornuarietis by Demian \& Yousif (1973b) and $P$. canaliculata by Koch et al. (2009) (see Development: Digestive Tract). Pyramidal cells 
have large nuclei and conspicuous nucleoli, and are polyploid, with a nuclear DNA content ranging from 4 to $16 \mathrm{C}$ (Cueto et al., 2006). This large DNA endowment is correlated with great development of the rough endoplasmic reticulum (Koch et al., 2006, 2009), which may contribute to the secretion of the multiple lamellae of $\mathrm{K}$ corpuscles (Koch et al., 2006).

Both $\mathrm{C}$ and $\mathrm{K}$ corpuscles contain chlorophylllike pigments identified as steryl pheophorbides (Vega et al., 2012b). However, because the shell filters out most photosynthetically active radiation (Dellagnola, 2010) and the pheophorbides are not suitable for light harvesting, their significance is not clear. They may be interpreted as evolutionary remnants in a formerly photosynthetic organism that has been strongly modified by endosymbiosis in darkness.

\section{IMMUNE DEFENSES}

Molluscs, as all invertebrates so far investigated, possess defense mechanisms analogous to those of the innate immune system of vertebrates that are based mainly on cellular responses and on circulating and fixed lectins (Ottaviani, 2006, 2011). They serve a variety of functions, such as recognition and phagocytosis of invaders (Bayne, 1983), capsule formation around parasites (e.g., Yousif et al., 1980; Lv et al., 2009b), hemostasis, wound healing, shell formation and repair (Franchini \& Ottaviani, 2000) and storage/transport of nutrients (e.g., Travers et al., 2008). Hemocytes have also been involved in stress response through the release of vertebrate-like endocrine molecules (Ottaviani et al., 1991).

Development of in vitro culture systems for ampullariid hemocytes may be critical for understanding many aspects of their biology. However, a culture system has only been reported for $P$. canaliculata (see Cueto et al., 2013); it uses a medium mimicking the physicochemical and chemical characteristics of the snail's internal milieu (Cueto et al., 2011).

\section{Ampullariid Hemocytes}

Substantial information has been gathered regarding hemocyte structure and function in the ampullariids Pila globosa (see Mahilini \& Rajendran, 2008) and P. canaliculata (Shozawa \& Suto, 1990; Cueto et al., 2007, 2013, submitted; Ray et al., 2012; Accorsi et al., 2013). Recent authors (Mahilini \& Rajendran, 2008;
Ray et al., 2012; Accorsi et al., 2013) have used various names for the different kinds of hemocytes, but in an attempt to standardize the nomenclature, Cueto et al. (submitted) adopted the classical terminology of Cheng (1975), recognizing three types: agranulocytes, hyalinocytes and granulocytes.

Agranulocytes constitute $28 \%$ of circulating cells in $P$. canaliculata according to Cueto et al. (2013) and are likely to include circulating blasts (Ray et al., 2012; Accorsi et al., 2013), though this hypothesis needs testing. Hyalinocytes are larger cells with membrane-bound granules of moderate electron density and may be lysosomes (Cueto et al., submitted). Approximately one quarter of circulating hyalinocytes show phagocytic activity and may participate in circulation and storage of glycogen (Cueto et al., 2013). Granulocytes are about the size of hyalinocytes but show no evidence of phagocytosis. They contain conspicuous eosinophilic granules that are membrane-bound, large and rod-shaped and show a high electron density. These granules merge and form even larger ones when granulocytes are exposed to microbes and may degranulate in a kind of "compound exocytosis" (Pickett \& Edwardson, 2006). Degranulation of granulocytes has been linked to the release of lysozyme and other bactericidal hydrolases in other molluscs (e.g., Ottaviani, 1991).

Hemocyte-Producing Organs and/or Immune Barriers

Many authors have reported that gastropod hemocytes are generated in the circulation (Sminia, 1981; Monteil \& Matricon-Gondran, 1991; van der Knaap et al., 1993; Souza \& Andrade, 2006). However, "amoebocyteproducing organs" have also been reported in the pericardial wall of some heterobranchs (Lie et al., 1975; Rondelaud \& Barthe, 1982; Jeong et al., 1983; Ruellan \& Rondelaud, 1992) and in the roof of the lung of $M$. cornuarietis (see Yousif et al., 1980). No such organs have been found in $P$. canaliculata, although spheroidal hemocyte aggregates, similar to those formed in vitro (Cueto et al., 2013), were found in the lung following injection of yeast cells into the visceral hump (Rodriguez et al., 2012), suggesting a role of the hemocytes in fighting infection. Also, large hemocyte islets occupy the hemocoelic spaces in the kidney of $P$. canaliculata (Cueto, 2011; Giraud-Billoud et al., 2013b; Cueto et al., submitted), and it is possible that 
TABLE 5. Mean metal concentrations (mg/kg dry weight) in the soft tissues of apple snails reported in previous studies. (Dashes indicate no data available.)

\begin{tabular}{|c|c|c|c|c|c|c|}
\hline Species and tissue & $\mathrm{Cu}$ & $\mathrm{Cd}$ & $\mathrm{Pb}$ & $\mathrm{Zn}$ & Location & Reference \\
\hline Pila ovata (viscera) & $2.0-5.8$ & - & - & $23.6-45.0$ & Southern Nigeria & $\begin{array}{l}\text { Ezemonye et al., } \\
2006\end{array}$ \\
\hline 'Pila ovum'1 & 24.6 & 1.0 & 4.8 & - & Southwestern Nigeria & $\begin{array}{l}\text { Adewunmi et al., } \\
1996\end{array}$ \\
\hline Lanistes libycus & 48.2 & 0.8 & 5.42 & - & Southwestern Nigeria & $\begin{array}{l}\text { Adewunmi et al., } \\
1996\end{array}$ \\
\hline $\begin{array}{l}\text { Pomacea canaliculata } \\
\text { (head-foot) }\end{array}$ & $32-90$ & $0.4-2.5$ & $5 \quad 5-32$ & $70-240$ & Guangdong, China & $\begin{array}{l}\text { Deng et al., } \\
2008\end{array}$ \\
\hline $\begin{array}{l}\text { Pomacea canaliculata } \\
\text { (viscera) }\end{array}$ & $60-170$ & $5-29$ & $160-620$ & $3000-6400$ & Guangdong, China & $\begin{array}{l}\text { Deng et al., } \\
2008\end{array}$ \\
\hline Pomacea paludosa & $23.9-732$ & - & - & - & Florida, USA & $\begin{array}{l}\text { Frakes et al., } \\
2008\end{array}$ \\
\hline $\begin{array}{l}\text { Pomacea paludosa } \\
\text { (foot) }\end{array}$ & $44-145$ & - & - & - & Florida, USA & $\begin{array}{l}\text { Hoang et al., } \\
2008\end{array}$ \\
\hline $\begin{array}{l}\text { Pomacea paludosa } \\
\text { (viscera) }\end{array}$ & $75-229$ & - & - & - & Florida, USA & $\begin{array}{l}\text { Hoang et al., } \\
2008\end{array}$ \\
\hline
\end{tabular}

${ }^{1}$ Misnamed; could be either Lanistes ovum Troschel, 1845 or Pila ovata.

they function as a hemocyte-producing organ. Also, hemocyte spheroids are formed in these islets after the injection of yeast cells in the foot (Rodriguez et al., 2012), demonstrating the reactivity of the islets to an immune challenge. The presumptive hemopoietic role of the lung roof and the kidney in ampullariids needs to be further explored, but their role as immune barriers against intruders seems clear.

\section{ENVIRONMENTAL HEALTH AND POLLUTION}

This review has focused thus far on the basic biology of ampullariids. However, there are important applied issues, notably their role as major agricultural pests, environmental pests, vectors of human disease and in ecotoxicology. Their role as crop pests, primarily of rice in Asia but also of taro and other crops in Asia and elsewhere, has been thoroughly reviewed elsewhere (Cowie, 2002; Joshi \& Sebastian, 2006), and the limited understanding of their importance as environmental pests has been covered in the present review. However, their role in ecotoxicological research has been extensive in the last two decades but has not been reviewed. Also, important work regarding their role as human parasitic disease vectors has appeared since the review of Hollingsworth \& Cowie (2006). Therefore these topics are reviewed briefly.

\section{Accumulation of Pollutants}

Several reports, notably from Nigeria, China and Florida, of heavy metal concentrations have shown that apple snails have the potential to accumulate high concentrations of these elements in their tissues, especially the viscera (Table 5). Thus they have the potential to affect animals at higher trophic levels, including humans. The high tissue concentrations of lead and zinc reported in $P$. canaliculata from a lead/ zinc mine in southern China were probably due to accumulation and detoxification through binding to proteins or ligands, as in Lymnaea stagnalis (Linnaeus, 1758) (Desouky, 2006), rather than contamination by sediment. In some cases, there is a positive correlation between tissue burden and environmental concentration of toxicants, such that these ampullariids may serve as bioindicators of environmental pollution.

Vega et al. (2012b) determined the bioconcentration factors (BCFs) for a range of elements in tissues, eggs and midgut gland 
endosymbionts of $P$. canaliculata. The highest BCF was exhibited by barium (Ba) in all studied tissues, including the pallial oviduct, as well as the eggs, which showed the lowest BCFs for the other elements, suggesting the existence of a barrier protecting the eggs from most metal pollutants. Other tissues exhibited a range of $\mathrm{BCF}$ s for other elements. The BCFs for barium were extremely high in the intracellular endosymbionts ( $\mathrm{C}$ and $\mathrm{K}$ morphotypes) and other more toxic pollutants (e.g., uranium, mercury, arsenic, bromine) were also heavily concentrated. The endosymbionts are released in the snail's feces so may serve a detoxification function.

The accumulation of metal pollutants by ampullariids and their endosymbionts indicates the potential harm of using these snails as soil fertilizers or animal food (Halwart, 1994; Vega et al., 2012a). Also, ampullariids are considered a delicacy in some parts of the world (DiupotexChong et al., 2004; Eamsobhana et al., 2010; Lv et al., 2011), and industrial development in such areas may transform these traditional foods into hazardous ones. In Florida, P. paludosa have high tissue concentrations of copper, accumulated primarily via the diet, related to high levels in the sediment due to the use of copper-based fungicides in citrus plantations, which is thus a serious concern for the Everglades snail kite (Rogevich et al., 2008).

\section{Toxicity of Pollutants to Apple Snails}

Apple snail toxicity assays for metals and organic pesticides appear very sensitive (Sawasdee \& Köhler, 2009), and apple snails may therefore have potential as toxicity test organisms. However, their responses to different pollutants are complex and not broadly understood. For example, the toxicity of copper, to which Pomacea spp. are especially sensitive (Cazzaniga, 1981; Sun, 2013), may depend on a number of factors, including animal age and such water quality parameters as $\mathrm{pH}$ and dissolved oxygen concentration (Rogevich et al., 2008; Sun, 2013). In adult $P$. canaliculata, there are also complex feeding and growth rate relationships to exposure time and copper concentration (Peña \& Pocsidio, 2007). Few studies have investigated the detailed responses to toxins. However, in sublethal toxicity tests on $M$. cornuarietis embryos, in which copper and nickel were more toxic than other metals, there were significant delays in formation of tentacles and eyes; and various concentrations of zinc, palladium, nickel and lithium also reduced heart rate or resulted in a delay in hatching (Sawasdee \& Köhler, $2009,2010)$. Toxicity assays have also been conducted using organic pesticides, including Diclobenil, Diuron and Simizina (Cazzaniga, 1981) and Paraquat (Melo et al., 2000). The effects of Atrazine and Imidacloprid on hatching rate of embryos have been investigated, with the former much more toxic (Sawasdee \& Köhler, 2009). However, it is even more difficult to draw broad conclusions about the effects of such pesticides, not only because only very few studies have been undertaken on the immense diversity of pesticides in use but also because of lack of methodological standardization and a focus on either lethal or specific sublethal effects in different studies.

\section{Mechanisms of Toxicity}

The above studies have evaluated both lethal and non-lethal toxicity, mostly driven by the need for control of pest apple snails and environmental monitoring, but little is known about the mechanisms actually causing the toxicity. For example, several hypotheses have been proposed to explain the endocrine disrupting effects of organotins on female snails, although none appears exclusive (Oehlmann et al., 2007). The masculinizing compound tributyltin (TBT) induces lipid and fatty acid accumulation in female $M$. cornuarietis according to Janer et al. (2007), just as organotin compounds induce adipogenesis in vertebrates through interaction with retinoid $X$ receptor $(R X R)$ and peroxisome proliferator-activated y receptor (Grün et al., 2006). In the neogastropod Thais clavigera (Küster, 1860), TBT also binds to RXR with high affinity (Nishikawa et al., 2004). In addition, TBT has spermicidal action, targeting the seminal receptacle (Giraud-Billoud et al., 2013c).

As well as effects on survival of juveniles and adults, endocrine disrupting effects have been reported in females exposed to several environmental contaminants, including TBT and TPT (triphenyltin), at different ages from hatching to adulthood (Schulte-Oehlmann et al., 1995, 2000; Tillmann et al., 2001). However, during development, different physiological control mechanisms may be acting at different times, each potentially generating different responses to pollutants. Because masculinizing substances act on the copulatory rudiment that is normally present in juvenile and adult female apple snails (e.g., Schulte-Oehlmann et al., 2000) and because this rudiment continues to grow even after females reach sexual 
maturity (Gamarra-Luques et al., 2013), studies of female masculinization ("imposex") in ampullariids should consider age at exposure (Giraud-Billoud et al., 2013c).

The endocrine disrupting effects of bisphenol $A$ are less clear than those of masculinizing pollutants. Bisphenol A has estrogenic effects on many aquatic invertebrates (Kang et al., 2007). In M. cornuarietis females, exposure at low concentrations resulted in formation of additional female organs, enlarged accessory sex glands, malformations of the pallial oviduct, enhanced egg and clutch production, and increased female mortality (Oehlmann et al., 2000, 2006). However, these studies were criticized for flaws in experimental design, analysis and interpretation (Staples et al., 2002; Dietrich et al., 2006). Subsequent studies exposing $M$. cornuarietis at higher concentrations detected no effect on eggs/female/month, percentage of eggs hatching successfully and time to hatching (Forbes et al., 2007a, b) and showed that a major part of the variability in such traits was simply individual differences (Forbes et al., 2008).

Sun (2013) examined the responses of the proteome of juvenile $P$. canaliculata after exposure to copper and cadmium. Eleven differentially expressed proteins were identified that function in many vital cellular functions, such as antioxidation, energy metabolism, detoxification, signaling transduction and cytoskeleton disruption. Although some of these functions are non-specific stress responses (i.e., antioxidation and energy metabolism), others may serve as biomarkers of exposure as they may be related to metal toxicity pathways.

\section{HUMAN HEALTH CONCERNS}

At least three human diseases are caused by transmission of parasites from ampullariids: angiostrongyliasis or rat lungworm disease caused by the nematode Angiostrongylus cantonensis, cercarial dermatitis or swimmer's itch caused by schistosome cercariae, and echinostomiasis caused by species in the trematode genus Echinostoma. The following brief review updates that of Hollingsworth \& Cowie (2006).

\section{Angiostrongyliasis}

Infection by $A$. cantonensis, the rat lungworm, is the most common cause of eosinophilic meningitis worldwide (Graeff-Teixeira et al., 2009; Cowie, 2013a). It is an acute disease, with mild infections spontaneously resolving in a few weeks, but heavier infections sometimes entailing serious sequelae, although rarely death (Dorta-Contreras et al., 2009; Graeff-Teixeira et al., 2009; Cowie, 2013a; Murphy \& Johnson, 2013). Widely and probably naturally occurring in much of Southeast Asia, this zoonosis is by far the most serious disease transmitted by ampullariids. It has been considered an emerging disease, as its geographical range has been expanding rapidly in recent years (Lv et al., 2011; Cowie, 2013a; Morassutti et al., 2014), and it has now been reported from over 30 countries (Wang et al., 2008; Cowie, 2013b; Kim et al., 2014). As development of the larvae depends on the temperature of their intermediate snail hosts, for example, P. canaliculata (Lv et al., 2006), global climate change may lead to further range expansion (Lv et al., 2011). However, with the exception of the many cases in parts of Asia, most reports are not associated with ampullariids.

The life cycle of $A$. cantonensis (GraeffTeixeira et al., 2009; Cowie, 2013b) involves rats as definitive hosts and numerous species of terrestrial and freshwater gastropods as intermediate hosts (Kim et al., 2014), including a number of ampullariid species (Table 6). Humans become infected mainly through ingestion of raw or undercooked snails (as well as crabs or other paratenic hosts) (Cowie, 2013c). Deliberate ingestion is the primary route of infection in parts of Asia. In southern China, where non-native $P$. canaliculata is widespread, the number of cases of angiostrongyliasis has been increasing, with most cases directly related to the deliberate consumption of introduced $P$. canaliculata, which is currently considered the main cause of the spread of the disease in China (Lv et al., 2008, 2009a, b, 2011; Yang et al., 2013). Pomacea canaliculata is also a major source of infection in Taiwan (Tsai et al., 2013). Similarly, in Thailand, native Pila spp. are widely eaten and the main source of infection (Eamsobhana et al., 2010). Inadvertent ingestion of infected snails associated with vegetables, green salads, fresh vegetable juice and other produce is also an important avenue of infection (Lv, 2009a; Cowie, 2013c), but ingestion of larvae on produce contaminated with snail slime, drinking of contaminated water, or via breaks in the skin have not been demonstrated and ampullariids have not been implicated in these infection pathways (Hollingsworth \& Cowie, 2006; Cowie, 2013c). 
TABLE 6. Known ampullariid hosts of Angiostrongylus cantonensis. Data from Kim et al. (2014). (*Experimental infection only.)

\begin{tabular}{ll}
\hline \multicolumn{1}{c}{ Species } & \multicolumn{1}{c}{ Location } \\
\hline $\begin{array}{l}\text { Lanistes carinatus (Olivier, 1804) } \\
\text { Marisa cornuarietis (Linnaeus, 1758) } \\
\text { Pila ampullacea (Linnaeus, 1758) }\end{array}$ & Egypt \\
Pila angelica (Annandale, 1920)* & Thailand \\
Pila gracilis (Lea, 1856) & \\
Pila pesmei (Morlet, 1889) & Thailand \\
Pila scutata (Mousson, 1848) & Thailand \\
Pila turbinis (Lea, 1856) & Indonesia, Malaysia, Thailand \\
Pila virescens (Deshayes, in Bory de Saint Vincent, 1824) & Thailand \\
[as polita Deshayes, 1830] & China, Thailand \\
Pomacea canaliculata (Lamarck, 1822) & China, Hawaii, Okinawa (Japan), Taiwan \\
Pomacea lineata (Spix in Wagner, 1827) & Brazil \\
Pomacea maculata Perry, 1810 & China, Louisiana (USA) \\
Pomacea paludosa (Say, 1829) & Cuba, Hawaii (possible misidentification) \\
\hline
\end{tabular}

According to published reports, abdominal angiostrongyliasis caused by the closely related Angiostrongylus costaricensis, primarily in South and Central America (Rodriguez et al., 2008), is not associated with ampullariids.

\section{Cercarial Dermatitis}

Various trematode parasites of birds and mammals use freshwater snails as intermediate hosts (Brown, 1994; Muller, 2002). Transmission is achieved by swimming larvae, that is, the miracidia and cercariae that are infective to the intermediate and definitive hosts, respectively (Muller, 2002). Species of the genus Schistosoma are by far the most important trematodes from a medical viewpoint as they cause schistosomiasis that affects millions of people in tropical regions (Muller, 2002). Various species of other genera of Schistosomatidae may cause cercarial dermatitis or swimmer's itch in humans, in which the cercariae penetrate the skin but do not develop further (Muller, 2002; Burke \& Tester, 2002). Among ampullariids, only P. paludosa has been definitively demonstrated as a vector, and only of cercarial dermatitis, in Florida (Hanning \& Leedom, 1978). In Brazil, although there is no record of cercarial dermatitis associated with species of Pomacea, schistosomatid cercariae have been detected in $P$. lineata and
P. maculata by Mattos et al. (2013) and in $P$. figulina by Thiengo (unpublished).

\section{Echinostomiasis}

Human echinostomiasis is a food-borne, zoonotic parasitosis attributed to various species of digenean trematodes, many of which are transmitted by freshwater snails. This zoonosis, endemic in Southeast and eastern Asia, causes intestinal problems involving severe diarrhea and abdominal pain, eosinophilia, edema and hepatomegaly (Eveland \& Haseeb, 2003; Graczyk \& Fried, 1998). The life cycle of Echinostoma spp. involves birds and small mammals as definitive hosts, and snails, clams, and fishes as first and second intermediate hosts. Humans become infected through the ingestion of raw or undercooked intermediate hosts infected with the metacercariae of the parasite.

Eating raw or undercooked Pila Iuzonica (Reeve, 1856) (probably a synonym of Pila scutata) has been considered the main route of transmission in the Philippines (Graczyk \& Fried, 1998), though it is also possible that because of the difficulty non-experts have in distinguishing ampullariid species, $P$. canaliculata, which is now widely distributed in the Philippines (Hayes et al., 2008), is involved. In Thailand, Pila spp. and $P$. canaliculata (and perhaps $P$. maculata, with which $P$. canaliculata 
has frequently been confused; Hayes et al., 2008,2012 ) have been identified as intermediate hosts of Echinostoma spp. (Weerachai et al., 2011). The high incidence of the disease in northern Thailand (Graczyk \& Fried, 1998) and other parts of Asia is probably also a result of consuming raw apple snails, as for angiostrongyliasis (Eamsobhana et al., 2010).

\section{CONCLUSION AND FUTURE RESEARCH OPPORTUNITIES}

The large amount of information that has been gathered makes the Ampullariidae one of the more intensively studied families of Gastropoda. However, nearly all studies have focused on a single species, $P$. canaliculata, and have done so in a non-comparative context, limiting their general applicability for understanding the biology of the family as a whole. These two issues suggest the need for (1) comparative data for other species to provide insight into the evolution, ecology and biology of Ampullariidae broadly, and (2) information on particular areas of the biology of $P$. canaliculata, particularly (but not exclusively) genomics, which would support the development of this species, and perhaps other apple snails, as "emerging model organisms" in physiology, development and ecology (in the sense of Behringer et al., 2008). The significance of the family as a model for studies in evolutionary and invasion biology in particular has already been discussed by Hayes et al. (2009a). Additional priorities for future ampullariid research, in no particular order, are:

- Integrative eco-physiological and comparative genomic studies aimed at understanding the evolution of the family as a whole and the novel behavioral, biochemical, anatomical and physiological traits that may have driven diversification and transitions among habitats.

- Comparative behavioral studies to reveal patterns across genera and within the family that may have played a role in ecological adaptation and speciation.

- Proteomic and biochemical studies of perivitellins and associated egg proteins to explore their origins, functions and ecological and evolutionary roles in diversification.

- Functional anatomical studies of male and female reproductive systems, particularly as they relate to evolution and ecology of amphibious traits and behavior.
- Phylogenetics, systematics and biogeography of Old World Ampullariidae.

- Integrative studies exploring the role of behavior, sexual selection and trophic ecology in the invasive and evolutionary success of the family.

- Studies integrating population genomics and captive rearing to better understand the role of hybridization in the native and non-native ranges of ampullariids.

- Comparative evolutionary-developmental studies.

- Ampullariid medical malacology, particularly at the interface of disease ecology and invasion biology.

- Ecosystem services provided by ampullariids, particulary in the context of conservation.

In all studies on ampullariid evolution and ecology, there is a need for a deeper and broader comparative investigation into the degree of dependence on aquatic and terrestrial resources for all species and the processes that have driven adaptations (Hayes et al., 2009a). For example, the shift to aerial oviposition in some groups was probably a key event in ampullariid evolution (Hayes et al., 2009a). Apple snail eggs provide an exceptional model to study the evolution of biochemical and physiological adaptations, which may have profound implications for addressing questions of ecology and evolution (Dreon et al., 2013).

Among predator avoidance tactics, the egg defenses of $P$. canaliculata open new perspectives on the study of aposematism (Dreon et al., 2010). Further studies on perivitellins of other ampullariids, particularly of below-water egg laying species, will reveal if this peculiar group of proteins is an acquisition exclusive to the aerial egg laying ampullariids.

There is therefore a clear need for more comparative work on the factors that shaped the evolution of amphibious traits. This will allow a better understanding of the successful reproductive strategy of Pomacea species and the selective pressures that have driven these acquisitions. Ampullariids and their close relatives offer a unique and potentially powerful system for addressing the physiological and behavioral ramifications of the transition from aquatic to terrestrial modes of life.

Additional specific areas of need and opportunity include the basic documenting of species diversity, especially in Africa and Asia, considerable progress having already been made in this regard in South America (Hayes et al., 2009b), and the resulting understand- 
ing of evolutionary patterns has provided the necessary framework for interpreting many of the studies discussed herein. There remains much more that could be learned regarding detailed aspects of life-history and its variation, even of the most well understood species $(P$. canaliculata and to a lesser extent $P$. maculata), which in a comparative framework could enlighten fundamental ideas about the evolution of life histories. Much basic ecology remains to be discovered, including how such abiotic factors as water level, temperature and quality influence apple snail behavior. Population dynamics, including the impacts of predation, has barely been addressed. Finally, there remain fascinating questions arising from the invasion of apple snails into new regions, which can be considered a natural experiment in evolution and ecology (Hayes et al., 2009a).

\section{ACKNOWLEDGEMENTS}

The idea for this review originated at the 4th International Workshop on the Biology of Ampullariidae (POMACEA 2010), San Miguel de Tucumán, Argentina (November 16-20, 2010), organized by Horacio Heras, María Gabriela Cuezzo and the late Beatriz C. Winik. Writing the review was supported by grants from: the U.S. National Science Foundation to $\mathrm{R}$. $\mathrm{H}$. Cowie, K. A. Hayes, S. C. Thiengo and E. E. Strong (DEB-0949061) and R. L. Burks, K. A. Hayes and R. H. Cowie (OISE-1130694); the Universidad Nacional del Sur to P. R. Martín (PGI 24B/185); CONICET, Argentina to P. R. Martín (PIP 112200901 00473), A. CastroVazquez (PIP 11220110100052 ) and I. A. Vega (2012-2014); ANPCyT, Argentina to P. R. Martín (PICT 2012-1956), A. Castro-Vazquez (PICT 2013-1190) and H. Heras (PICT 20111428, PICT 2008-1865); the Universidad Nacional de la Plata (N-684) to $\mathrm{H}$. Heras; and the Universidad Nacional de Cuyo to I. A. Vega, M. Giraud-Billoud and A. Castro-Vazquez.

\section{LITERATURE CITED}

ACCORSI, A., L. BUCCI, M. DE EGUILEOR, E. OTTAVIANI \& D. MALAGOLI, 2013, Comparative analysis of circulating hemocytes of the freshwater snail Pomacea canaliculata. Fish \& Shellfish Immunology, 34: 1260-1268.

ACOSTA, B. O. \& R. S. V. PULLIN, 1991, Environmental impact of the golden snail (Pomacea sp.) on rice farming systems in the Philippines. Freshwater Aquaculture Center, Central Luzon
State University, Munoz, Nueva Ecija; ICLARM, Manila, vi + 34 pp.

ADEWUNMI, C. O., W. BECKER, O. KUEHNAST, F. OLUWOLE \& G. DÖRFLER, 1996, Accumulation of copper, lead and cadmium in freshwater snails in southwestern Nigeria. Science of the Total Environment, 193: 69-73.

ADITYA, G. \& S. K. RAUT, 2001, Food of the snail, Pomacea bridgesi, introduced in India. Current Science, 80: 919-921.

ADITYA, G. \& S. K. RAUT, 2002, Destruction of Indoplanorbis exustus (Planorbidae) eggs by Pomacea bridgesi (Ampullariidae). Molluscan Research, 22: 87-90.

AIZAKI, K. \& Y. YUSA, 2009, Field observations of the alarm response to crushed conspecifics in the freshwater snail Pomacea canaliculata: effects of habitat, vegetation, and body size. Journal of Ethology, 27: 175-180.

AIZAKI, K. \& Y. YUSA, 2010, Learned predator response in a freshwater snail, Pomacea canaliculata. Malacologia, 52: 21-29.

ALBRECHT, E., 1998, Control de la estacionalidad reproductiva en el gastrópodo Pomacea canaliculata (Prosobranchia, Ampullariidae). Ph.D. thesis, Universidad Nacional de Cuyo, Mendoza, $148 \mathrm{pp}$.

ALBRECHT, E., N. CARREÑO \& A. CASTROVAZQUEZ, 1996, A quantitative study of copulation and spawning in the South American applesnail, Pomacea canaliculata (Prosobranchia: Ampullariidae). The Veliger, 39: 142-147.

ALBRECHT, E., N. CARRENO \& A. CASTROVAZQUEZ, 1999, A quantitative study of environmental factors influencing the seasonal onset of reproductive behaviour in the South American apple-snail Pomacea canaliculata (Gastropoda: Ampullariidae). Journal of Molluscan Studies, 65: 241-250.

ALBRECHT, E. A., E. KOCH, N. B. CARREÑO \& A. CASTRO-VAZQUEZ, 2005, Control of the seasonal arrest of copulation and spawning in the apple snail Pomacea canaliculata (Prosobranchia: Ampullariidae): differential effects of food availability, water temperature, and day length. The Veliger, 47: 169-174.

ANDREWS, E. B., 1964, The functional anatomy and histology of the reproductive system of some pilid gastropod molluscs. Proceedings of the Malacological Society of London, 36: 121-140.

ANDREWS, E. B., 1965, The functional anatomy of the mantle cavity, kidney and blood system of some pilid gastropods (Prosobranchia). Journal of Zoology, 146: 70-94.

ANNANDALE, N., 1920, The apple-snails of Siam. Journal of the Natural History Society of Siam, 4(1): 1-24.

ANONYMOUS, 2011, Pest risk analysis on the introduction of Pomacea insularum (d'Orbigny, $1835)$ into the EU. Ministerio de Medio Ambiente y Medio Rural y Marino, Spain, $45 \mathrm{pp}$.

ANTO, F., K. BOSOMPEM, J. KPIKPI, M. ADJIK \& D. EDOH, 2005, Experimental control of Biomphalaria pfeifferi, the intermediate host of 
Schistosoma mansoni, by the ampullariid snail Lanistes varicus. Annals of Tropical Medicine and Parasitology, 99: 203-209.

ANTON, H. E., 1838, Verzeichniss der Conchylien welche sich in der Sammlung von Hermann Eduard Anton befinden. Eduard Anton, Halle, $\mathrm{xvi}+110 \mathrm{pp}$.

ATHAWALE, M. \& S. REDDY, 2002, Storage excretion in the Indian apple snail, Pila globosa (Swainson), during aestivation. Indian Journal of Experimental Biology, 40: 1304-1306.

AVERBUJ, A., G. BIGATTI \& P. E. PENCHASZADEH, 2010, Gametogenic cycle and size at first maturity of the Patagonic edible snail Buccinanops cochlidium from Argentina. Marine Biology, 157: 2229-2240.

BACHMANN, A., 1960, Apuntes para una hidrobiología argentina. II. Ampullaria insularum Orb. y A. canaliculata Lam. (Moll. Prosobr., Ampullaridae). Observaciones biológicas y ecológicas. Actas y Trabajos del Primer Congreso Sudamericano de Zoología, 1: 19-26.

BAHL, K. N., 1928, On the reproductive processes and development of Pila globosa (Swainson). Part I, Copulation and oviposition. Memoirs of the Indian Museum, 9: 1-11.

BAKER, G. H., 1998, The golden apple snail, Pomacea canaliculata (Lamarck) (Mollusca: Ampullariidae), a potential invader of fresh water habitats in Australia. Pp. 21-26, in: M. P Zalucki, R. A. I. Drew \& G. G. White, eds., Pest management - future challenges. Proceedings of the sixth Australasian applied entomological research conference. Brisbane, Australia. 29 September-2nd October 1998, Volume 2. University of Queensland, Brisbane.

BAKER, H. B., 1922, The Mollusca collected by the University of Michigan - Walker expedition in southern Vera Cruz, Mexico. I. Occasional Papers of the Museum of Zoology, University of Michigan, 106: 1-95.

BAKER, P., F. ZIMMANCK \& S. M. BAKER, 2010, Feeding rates of an introduced freshwater gastropod Pomacea insularum on native and nonindigenous aquatic plants in Florida. Journal of Molluscan Studies, 76: 138-143.

BANDEL, K., 1998, Evolutionary history of East African fresh water gastropods interpreted from the fauna of Lake Tanganyika and Lake Malawi. Zentralblatt für Geologie und Paläontologie, 1 : 233-292.

BARNES, M. A., R. K. FORDHAM \& R. L. BURKS, 2008, Fecundity of the exotic applesnail, Pomacea insularum. Journal of the North American Benthological Society, 27: 738-745.

BAYNE, C. J., 1983, Molluscan immunobiology. Pp. 407-486, in: A. SALEUDDIN \& K. WILBUR, eds., The Mollusca. Volume 5: Physiology, Part 2. Academic Press, New York, 500 pp.

BEHRINGER, R. R., M. K. LEVINE, N. PATEL \& N. SINHA, 2008, Emerging model organisms: a laboratory manual, volume 1. Cold Spring Harbor Laboratory Press, New York, 592 pp.

BENSON, W. H., 1842, Mollusca. Annals and Magazine of Natural History, 9: 486-490.

BERGMANN, F. B., H. L. C. AMARAL, D. P. PINTO, C. C. CHIVITTZ \& A. M. TOZETTI, 2013,
Foraging activity of the snail kite, Rostrhamus sociabilis (Aves: Accipitridae) in wetlands of southern Brazil. Brazilian Journal of Biology, 73: 245-252.

BERTHOLD, T., 1989, Comparative conchology and functional morphology of the copulatory organ of the Ampullariidae (Gastropoda, Monotocardia) and their bearing upon phylogeny and palaeontology. Abhandlungen des Naturwissenschaftlichen Vereins in Hamburg, (NF)28: 141-164.

BERTHOLD, T., 1990, Phylogenetic relationships, adaptations and biogeographic origin of the Ampullariidae (Mollusca, Gastropoda) endemic to Lake Malawi, Africa. Verhandlungen des Naturwissenschaftlichen Vereins Hamburg, (NF)31/32: 47-84.

BERTHOLD, T., 1991, Vergleichende Anatomie, Phylogenie und historische Biogeographie der Ampullariidae (Mollusca, Gastropoda). Abhandlungen des Naturwissenschaftlichen Vereins in Hamburg, (NF)29: 1-256.

BIAN, Q.-Q., X.-Y Li, Y.-Q. Fang, Y.-Q. Jia \& X.-D. Mu, 2013, Molecular identification of Pomacea canaliculata and $P$. insularum from rice paddy in different origins in China using mitochondrial adenosine triphosphate subunit 6 gene. Mitochondrial DNA, doi:10.3109/19401736.20 13.830302

BIELER, R., 1993, Ampullariid phylogeny - book review and cladistic re-analysis. The Veliger, 36: 291-299.

BLAINVILLE, H. M. D. de, 1822, Note sur l'organisation de l'animal de l'Ampullaire. Journal de Physique, de Chimie et d'Histoire Naturelle, 95: 459-464.

BLUME, W., 1957, Eine bis heute unbekannte Interart von Pomacea bridgesi Rve. Opuscula Zoologica, 1: 1-2.

BOLAND, B. B., M. MEERHOFF, C. FOSALBA, N. MAZZEO, M. A. BARNES \& R. L. BURKS, 2008, Juvenile snails, adult appetites: contrasting resource consumption between two species of applesnails (Pomacea). Journal of Molluscan Studies, 74: 47-54.

BORN, I. von, 1778, Index rerum naturalium Musei Caesarei Vindobonensis. Pars Ima Testacea. Verzeichniß der natürlichen Seltenheiten des k. k. Naturalien Cabinets zu Wien. Erster Theil. Schalthiere. J. P. Kraus, Vindobonae [= Vienna], xlii + $458+$ [82] p., 1 pl.

BORY DE SAINT-VINCENT [J. B. G. M.], ed., 1824, Dictionnaire classique d'histoire naturelle. Planches. Cinquième livraison. Rey et Gravier, Baudouin Frères, Paris.

BOSS, K. J. \& J. J. PARODIZ, 1977, Paleospecies of Neotropical ampullariids and notes on other fossil non-marine South American gastropods. Annals of Carnegie Museum, 46: 107-127.

BOSSUYT, F. \& M. MILINKOVITCH, 2001, Amphibians as indicators of early Tertiary 'out-of-India' dispersal of vertebrates. Science, 292: 93-95.

BOUCHET, P. \& J.-P. ROCROI, 2005, Classification and nomenclator of gastropod families. Malacologia, 47: 1-397

BOXSHALL, G. A. \& E. E. STRONG, 2006, An extraordinary shift in life habit within a genus 
of cyclopid copepods in Lake Tanganyika. Zoological Journal of the Linnean Society, 146: 275-286.

BROOKS, W. \& B. McGLONE, 1908, The origin of the lung of Ampullaria. Carnegie Institution of Washington Publication, 102: 95-104.

BROWDER, J. A. P. J. GLEASON \& D. R. SWIFT, 1994, Periphyton in the Everglades: spatial variation, environmental correlates, and ecological implications. Pp. 379-418, in: J. OGden \& S. DAvis, eds., Everglades, the ecosystem and its restoration. St. Lucie Press, Delray Beach, Florida, $860 \mathrm{pp}$.

BRYAN, D. C., 1990, Apple snail densities at Alexander Springs, Lake County, and observations on snail ecology. Florida Scientist, 53 (Suppl. 1): 13.

BROWN, D. S., 1994, Freshwater snails of Africa and their medical importance, 2nd ed.Taylor \& Francis, London, $x+608+[1] \mathrm{pp}$.

BUCKLAND-NICKS, J., 1998, Prosobranch parasperm: sterile germ cells that promote paternity? Micron, 29: 267-280.

BUCKLAND-NICKS, J. \& F. S. CHIA, 1986, Fine structure of Sertoli cells in three marine snails with a discussion on the functional morphology of Sertoli cells in general. Cell and Tissue Research, 245: 305-313.

BUCKLAND-NICKS, J. \& A. SCHELTEMA, 1995 , Was internal fertilization an innovation of early Bilateria? Evidence from sperm structure of a mollusc. Proceedings of the Royal Society of London B, Biological Sciences, 261: 11-18.

BURELA, S. \& P. R. MARTíN, 2007, Nuptial feeding in the freshwater snail Pomacea canaliculata (Gastropoda: Ampullariidae). Malacologia, 49: 465-470.

BURELA, S. \& P. R. MARTÍN, 2009, Sequential pathways in the mating behavior of the apple snail Pomacea canaliculata (Caenogastropoda: Ampullariidae). Malacologia, 51: 157-164.

BURELA, S. \& P. R. MARTIN, 2011, Evolutionary and functional significance of lengthy copulations in a promiscuous apple snail, Pomacea canaliculata (Caenogastropoda: Ampullariidae). Journal of Molluscan Studies, 77: 54-64.

BURELA, S. \& P. R. MARTÍN, 2014, Nuptial gifts in Pomacea canaliculata (Ampullariidae, Caenogastropoda): experimental and field evidence about their function. Malacologia, 57(2): 319-327.

BURKE, W. A. \& P. A. TESTER, 2002, Skin problems related to noninfectious coastal microorganisms. Dermatologic Therapy, 15: 10-17.

BURKS, R. L., S. A. HENSLEY \& C. H. KYLE, 2011, Quite the appetite: juvenile island apple snails (Pomacea insularum) survive consuming only exotic invasive plants. Journal of Molluscan Studies, 77: 423-428.

BURKS, R. L., C. H. KYLE \& M. K. TRAWICK, 2010, Pink eggs and snails: field oviposition patterns of an invasive snail, Pomacea insularum, indicate a preference for an invasive macrophyte. Hydrobiologia, 646: 243-251.

BURKS, R. L. \& D. M. LODGE, 2002, Cued in: advances and opportunities in freshwater chemical ecology. Journal of Chemical Ecology, 28: 1901-1917.

BURKS, R. L., G. MULDERIJ, E. GROSS, I. JONES, L. JACOBSEN, E. VAN DONK \& E. JEPPESEN, 2006, Center stage: the crucial role of macrophytes in regulating trophic interactions in shallow lake wetlands. Pp. 37-59, in: R. Bobbink, B. Beltman, J. T. A. Verhoeven \& D. F. WHIGHAM, eds., Wetlands: functioning, biodiversity conservation, and restoration. SpringerVerlag, Berlin and Heidelberg, xxv + 315 pp.

BURKY, A. J., 1974, Growth and biomass production of an amphibious snail, Pomacea urceus (Muller) [sic], from the Venezuelan savannah. Journal of Molluscan Studies, 41: 127-143.

BURKY, K. A. \& A. J. BURKY, 1977, Buoyancy changes as related to respiroatory behavior in an amphibious snail, Pomacea urceus (Müller), from Venezuela. The Nautilus, 91: 97-104.

BURKY, A. J., J. PACHECO \& E. PEREYRA, 1972, Temperature, water, and respiratory regimes of an amphibious snail, Pomacea urceus (Müller), from the Venezuelan savannah. Biological Bulletin, 143: 304-316.

BURLAKOVA, L. E., A. Y. KARATAYEV, D. K. PADILLA, L. D. CARTWRIGHT \& D. N. HOLLAS, 2009, Wetland restoration and invasive species: apple snail (Pomacea insularum) feeding on native and invasive aquatic plants. Restoration Ecology, 17: 433-440.

BURLAKOVA, L. E., D. K. PADILLA, A. Y. KARATAYEV, D. N. HOLLAS, L. D. CARTWRIGHT \& K. D. NICHOL, 2010, Differences in population dynamics and potential impacts of a freshwater invader driven by temporal habitat stability. Biological Invasions, 12: 927-941.

BYERS, J. E., W. G. McDOWELL, S. R. DODD, R. S. HAYNIE, L. M. PINTOR \& S. B. WILDE, 2013, Climate and $\mathrm{pH}$ predict the potential range of the invasive apple snail (Pomacea insularum) in the southeastern United States. PLoS One, 8: e56812.

CARLSSON, N. O. L. \& C. BRÖNMARK, 2006, Size-dependent effects of an invasive herbivorous snail (Pomacea canaliculata) on macrophytes and periphyton in Asian wetlands. Freshwater Biology, 51: 695-704.

CARLSSON, N. O. L., C. BRÖNMARK \& L.-A. HANSSON, 2004a, Invading herbivory: the golden apple snail alters ecosystem functioning in Asian wetlands. Ecology, 85: 1575-1580.

CARLSSON, N. [O. L.] A. KESTRUP, $M$. MÅRTENSSON \& P. NYSTRÖM, 2004b, Lethal and non-lethal effects of multiple indigenous predators on the invasive golden apple snail (Pomacea canaliculata). Freshwater Biology, 49: 1269-1279.

CARLSSON, N. O. L. \& J. O. LACOURSIËRE, 2005 , Herbivory on aquatic vascular plants by the introduced golden apple snail (Pomacea canaliculata) in Lao PDR. Biological Invasions, 7: 233-241.

CASTELLANOS, Z. J. A. \& D. FERNANDEZ, 1976, Gastropoda Ampullariidae. Pp. 1-33, in: R. A. Ringuelet, ed., Fauna de agua dulce de la República Argentina. FECIC, Buenos Aires. 
CASTRO-VAZQUEZ, A., E. A. ALBRECHT, I. A. VEGA, E. KOCH \& C. GAMARRA-LUQUES, 2002, Pigmented corpuscles in the midgut gland of Pomacea canaliculata and other Neotropical apple-snails (Prosobranchia, Ampullariidae): a possible symbiotic association. Biocell, 26: 101-109.

CATALÁN, M., M. S. DREON, H. HERAS, R. J. POLLERO, S. N. FERNÁNDEZ \& B. WINIK, 2006, Pallial oviduct of Pomacea canaliculata (Gastropoda): ultrastructural studies of the parenchymal cellular types involved in the metabolism of perivitellins. Cell and Tissue Research, 324: 523-533.

CATALÁN, N. M. Y., S. N. FERNANDEZ \& B. C. WINIK, 2002, Oviductal structure and provision of egg envelops in the apple snail Pomacea canaliculata (Gastropoda, Prosobranchia, Ampullariidae). Biocell, 26: 91-100.

CATALÁN, M., C. SCHLICK DE SANTOLAYA \& B. WINIK, 1997, Ultrastructural study of eupyrene spermatozoon in the pond snail Ampullaria canaliculata (Gastropoda, Prosobranchia). Biocell, 21: 175-185.

CATALÁN DE CANELADA, N. M. Y. \& A. MORENO, 1984, Descripción del tracto intrauterino en el gasterópodo Ampullaria canaliculata. Neotropica, 30: 153-160.

CATTAU, C. E., J. MARTIN \& W. M. KITCHENS 2010, Effects of an exotic prey species on a native specialist: example of trhe snail kite. Biological Conservation, 143: 513-520.

CAZZANIGA, N. J., 1981, Evaluación preliminar de un gasterópodo para el control de malezas acuáticas sumergidas. Pp. 131-166, in: CIC, II Reunión sobre Malezas Subacuáticas en Canales de Desagüe de CORFO, La Plata, Buenos Aires.

CAZZANIGA, N. J., 1988, Hyalinella vahiriae (Ectoprocta) en la Provincia de San Juan. Revista de la Asociación de Ciencias Naturales del Litoral, 19: 205-208.

CAZZANIGA, N. J., 1990, Predation of Pomacea canaliculata (Ampullariidae) on adult Biomphalaria peregrina (Planorbidae). Annals of Tropical Medicine and Parasitology, 48: 97-100.

CAZZANIGA, N., 2006, Pomacea canaliculata: harmless and useless in its natural realm (Argentina). Pp. 37-60, in: R. C. Joshı \& L. C. SEBAstian, eds., Global advances in ecology and management of golden apple snails. Philippine Rice Research Institute, Muñoz, Nueva Ecija, Philippines, $x+588$ pp.

CAZZANIGA, N. J. \& A. L. ESTEBENET, 1984, Revisión y notas sombre los hábitos alimentarios de los Ampullariidae (Gastropoda). Historia Natural, 4: 213-224.

CEDEÑO-LEÓN, A. \& J. D. THOMAS, 1983, The predatory behaviour of Marisa cornuarietis on eggs and neonates of Biomphalaria glabrata, the snail host of Schistosoma mansoni. Malacologia, 24: 289-297.

CHATURVEDI, M. \& R. AGARWAL, 1981, Comparative study of storage pattern and site of synthesis of uric acid in the snails Viviparus bengalensis (Lamarck) and Pila globosa (Swain- son), during active and dormant periods. Indian Journal of Experimental Biology, 19: 130-134.

CHEESMAN, D. F., 1958, Ovorubin, a chromoprotein from the eggs of the gastropod mollusc Pomacea canaliculata. Proceedings of the Royal Society of London B, Biological Sciences, 149: 571-587.

CHENG, T. C., 1975, Functional morphology and biochemistry of molluscan phagocytes. Annals of the New York Academy of Sciences, 266: 343-379.

CHOUDHURY, R. \& R. PANDIT, 1997, Chromosomes of three prosobranch gastropods from Viviparidae, Pilidae and Cyclophoridae (Order: Mesogastropoda) Caryologia, 50: 303-315.

CLEDÓN, M., W. ARNTZ \& P. E. PENCHASZADEH, 2005, Gonadal cycle in Adelomelon brasiliana (Neogastropoda: Volutidae) population of Buenos Aires province, Argentina. Marine Biology, 147: 439-445.

CLEMENTS, R., L. P. KOH, T. M. LEE, R. MEIER \& D. LI, 2006, Importance of reservoirs for the conservation of freshwater molluscs in a tropical urban landscape. Biological Conservation, 128: 136-146.

COLES, G. C., 1968, The termination of aestivation in the large fresh-water snail Pila ovata (Ampulariidae) [sic] - I. Changes in oxygen uptake. Comparative Biochemistry and Physiology, 25: 517-522.

COLGAN, D. J., W. F. PONDER, E. BEACHAM \& J. M. MACARANAS, 2003, Gastropod phylogeny based on six segments from four genes representing coding or non-coding and mitochondrial or nucelar DNA. Molluscan Research, 23: $123-148$.

COLGAN, D. J., W. F. PONDER, E. BEACHAM \& J. MACARANAS, 2007, Molecular phylogenetics of Caenogastropoda (Gastropoda: Mollusca). Molecular Phylogenetics and Evolution, 42: 717-737.

CORRAO, N. M., P. C. DARBY \& C. M. POMORY, 2006, Nitrate impacts on the Florida apple snail, Pomacea paludosa. Hydrobiologia, 568: 135-143.

COWIE, R. H., 1997, Pila Röding, 1798 and Pomacea Perry, 1810 (Mollusca, Gastropoda): proposed placement on the Official List, and Ampullariidae Gray, 1824: proposed confirmation as the nomenclaturally valid synonym of Pilidae Preston, 1915. Bulletin of Zoological Nomenclature, 54: 83-88.

COWIE, R. H., 2001, Can snails ever be effective and safe biocontrol agents? International Journal of Pest Management, 47(1): 23-40.

COWIE, R. H., 2002, Apple snails (Ampullariidae) as agricultural pests: their biology, impacts and management. Pp. 145-192, in: G. M. BARKER, ed., Molluscs as crop pests. CABI, Wallingford, xii +400 pp.

COWIE, R. H., ed., 2013a, Eosinophilic meningitis caused by Angiostrongylus cantonensis, the rat lungworm: biology, distribution, epidemiology, detection, diagnosis, treatment, and management. Hawai'i Journal of Medicine and Public Health, 72 (Suppl. 2): 1-88. 
COWIE, R. H., 2013b, Biology, systematics, life cycle, and distribution of Angiostrongylus cantonensis, the cause of rat lungworm disease. Hawai'i Journal of Medicine and Public Health, 72 (Suppl. 2): 6-9.

COWIE, R. H., 2013c, Pathways for transmission of angiostrongyliasis and the risk of disease associated with them. Hawai'i Journal of Medicine and Public Health, 72 (Suppl. 2): 70-74.

COWIE, R. H. \& K. A. HAYES, 2012, Apple snails. Pp. 207-221, in: R. A. Francis, ed., A handbook of global freshwater invasive species. Earthscan, London, xxiv + 460 pp.

COWIE, R. H., K. A. HAYES \& S. C. THIENGO, 2006, What are apple snails? Confused taxonomy and some preliminary resolution. Pp. 3-23, in: R. C. Joshi \& L. C. Sebastian, eds., Global advances in ecology and management of golden apple snails. Philippine Rice Research Institute, Muñoz, Nueva Ecija, Philippines, $x+588$ pp.

COWIE, R. H., K. A. HAYES, C. T. TRAN \& P. LEVIN, 2007, Distribution of the invasive apple snail Pomacea canaliculata (Lamarck) in the Hawaiian Islands (Gastropoda: Ampullariidae). Bishop Museum Occasional Papers, 96: 48-51.

COWIE, R. H. \& V. HÉROS, 2012, Annotated catalogue of the types of Ampullariidae (Mollusca: Gastropoda) in the Muséum National d'Histoire Naturelle, Paris, with lectotype designations. Zoosystema, 34: 793-824.

COWIE, R. H. \& S. C. THIENGO, 2003, The apple snails of the Americas (Mollusca: Gastropoda: Ampullariidae: Asolene, Felipponea, Marisa, Pomacea, Pomella): a nomenclatural and type catalog. Malacologia, 45: 41-100.

CUETO, J. A., 2011, Pomacea canaliculata (Architaenioglossa, Ampullariidae): la hemolinfa y sus células. Ph.D. thesis, Universidad Nacional de Cuyo, Mendoza, $126 \mathrm{pp}$.

CUETO, J. A., T. FOGAL \& A. CASTROVAZQUEZ, 2007, Ultrastructural characterization of circulating hemocytes of Pomacea canaliculata. Biocell, 32: 103.

CUETO, J. A., M. GIRAUD-BILLOUD, I. A. VEGA \& A. CASTRO-VAZQUEZ, 2011, Haemolymph plasma constituents of the invasive snail Pomacea canaliculata (Caenogastropoda, Architaenioglossa, Ampullariidae). Molluscan Research, 31: 57-60.

CUETO, J. A., C. RODRIGUEZ, I. A. VEGA \& A. CASTRO-VAZQUEZ, submitted, Immune defenses of the apple snail Pomacea canaliculata (Architaenioglossa, Ampullariidae): hemocytes and organ barriers. PLOS ONE.

CUETO, J. A., I. A. VEGA \& A. CASTROVAZQUEZ, 2013, Multicellular spheroid formation and evolutionary conserved behaviors of apple snail hemocytes in culture. Fish \& Shellfish Immunology, 34: 443-453.

CUETO, J. A., I. A. VEGA, E. KOCH \& A. CASTRO-VAZQUEZ, 2006, Poliploidía en células que contienen a un endocianobionte de la glándula digestiva de Pomacea canaliculata (Caenogastropoda, Ampullariidae). Journal of Basic and Applied Genetics, 17 (Suppl. 2): 111.
DALL, W. H., 1904, Notes on the genus Ampullaria. Journal of Conchology, 11: 51-55.

DAMBORENEA, M. C., 1996, Patrones de distribución y abundancia de Temnocephala iheringi (Platyhelminthes, Temnocephalidae) en una población de Pomacea canaliculata (Mollusca Ampullariidae). Gayana, Zoología, 60: 1-12.

DAMBORENEA, [M.] C. \& F. BRUSA, 2008, A new species of Temnocephala (Platyhelminthes, Temnocephalida) commensal of Pomella megastoma (Mollusca, Ampullariidae) from Misiones, Argentina. Revista Mexicana de Biodiversidad, 79: 1S-7S.

DAMBORENEA, [M.] C., F. BRUSA \& A. PAOLA, 2006, Variation in worm assemblages associated with Pomacea canaliculata (Caenogastropoda, Ampullariidae) in sites near the Río de la Plata estuary, Argentina. Biocell, 30: 457-468.

DAMBORENEA, M. C. \& L. R. G. CANNON, 2001, On neotropical Temnocephala (Platyhelminthes). Journal of Natural History, 35: 1103-1118.

DAMBORENEA, M. C. \& B. S. GULLO, 1996, Hirudíneos asociados a la cavidad paleal de Pomacea canaliculata (Lamarck, 1822) (Gastropoda: Ampullariidae) del balneario Bagliardi, Rio de la Plata, Argentina. Neotropica, 42: 97-101.

DARBY, P. C., R. E. BENNETTS, J. D. CROOP, P. L. VALENTINE-DARBY \& W. M. KITCHENS, 1999, A comparison of sampling techniques for quantifying abundance of the Florida apple snail (Pomacea paludosa Say). Journal of Molluscan Studies, 65: 195-208.

DARBY, P. C., R. E. BENNETTS, S. J. MILLER \& H. F. PERCIVAL, 2002, Movements of Florida apple snails in relation to water levels and drying events. Wetlands, 22: 489-498.

DARBY, P. C., R. E. BENNETTS \& H. F. PERCIVAL, 2008, Dry down impacts on apple snail (Pomacea paludosa) demography: implications for wetland water management. Wetlands, 28: 204-214.

DARBY, P. C., D. J. MELLOW \& M. L. WATFORD, 2007, Food-handling difficulties for snail kites capturing non-native apple snails. Florida Field Naturalist, 35: 79-85.

DARBY, P., P. VALENTINE-DARBY \& H. PERCIVAL, 2003, Dry season survival in a Florida apple snail (Pomacea paludosa Say) population. Malacologia, 45: 179-184.

DE JONG-BRINK, M., H. H. BOER J. \& JOOSSE, 1983, Mollusca. Pp. 297-355, in: K. G. AdIYODI \& R. G. AdIYODI, eds., Reproductive biology of invertebrates, Vol. 1: Oogenesis, oviposition, oosorption. John Wiley \& Sons, New York, $770 \mathrm{pp}$.

DELLAGNOLA, F. A., 2010, Una simbiosis procariota-molusco: contribuciones funcionales y taxonómicas. Tesis de Licenciatura. Instituto de Ciencias Básicas, Universidad Nacional de Cuyo, Mendoza, Argentina, 52 pp.

DEMIAN, E. S. \& A. M. IBRAHIM, 1971, The eggs masses, egg laying and mating behavior of the snail Marisa cornuarietis (L.). Bulletin of the Zoological Society of Egypt, 23: 1-12. 
DEMIAN, E. \& A. M. IBRAHIM, 1972, Sexual dimorphism and sex ratio in the snail Marisa cornuarietis (L). Bulletin of the Zoological Society of Egypt, 24: 52-63.

DEMIAN, E. S. \& R. G. LUTFY, 1965a, Predatory activity of Marisa cornuarietis against Bulinus (Bulinus) truncatus, the transmitter of urinary schistosomiasis. Annals of Tropical Medicine and Parasitology, 59: 331-336.

DEMIAN, E. S. \& R. G. LUTFY, 1965b, Predatory activity of Marisa cornuarietis against Biomphalaria alexandrina under laboratory conditions. Annals of Tropical Medicine and Parasitology, 59: 337-339.

DEMIAN, E. S. \& R. G. LUTFY, 1966, Factors affecting the predation of Marisa cornuarietis on Bulinus (B.) truncatus, Biomphalaria alexandrina and Lymnaea caillaudi. Oikos, 17: 212-230.

DEMIAN, E. S. \& F. YOUSIF, 1973a, Embryonic development and organogenesis in the snail Marisa cornuarietis (Mesogastropoda, Ampullariidae). II. Development of the alimentary system. Malacologia, 12: 151-174.

DEMIAN, E. S. \& F. YOUSIF, 1973b, Embryonic development and organogenesis in the snail Marisa cornuarietis (Mesogastropoda: Ampullariidae). III. Development of the circulatory and renal systems. Malacologia, 12: 175-194.

DEMIAN, E. S. \& F. YOUSIF, 1973c, Embryonic development and organogenesis in the snail Marisa cornuarietis (Mesogastropoda: Ampullariidae). IV. Development of the shell gland, mantle and respiratory organs. Malacologia, 12: 195-211.

DEMIAN, E. S. \& F. YOUSIF, 1973d, Embryonic development and organogenesis in the snail Marisa cornuarietis (Mesogastropoda: Ampullariidae). I. General outlines of development. Malacologia, 12: 123-150.

DEMIAN, E. S. \& F. YOUSIF, 1975, Embryonic development and organogenesis in the snail Marisa cornuarietis (Mesogastropoda: Ampullariidae). V. Development of the nervous system. Malacologia, 15: 29-42.

DENG, P. Y., W. S. SHU, C. Y. LAN \& W. LIU, 2008 Metal contamination in the sediment, pondweed, and snails of a stream receiving effluent from a lead/zinc mine in southern China. Bulletin of Environmental Contamination and Toxicology, 81: 69-74

DESHAYES, G. P., 1830 [1830-1832], Encyclopédie méthodique. Histoire naturelle des vers. Tome second. Agasse, Paris, 1,152 pp.

DESHAYES, G. P. \& H. MILNE EDWARDS, 1838 , Histoire naturelle des animaux sans vertèbres.. Deuxième édition, Tome huitième. J. B. Baillière, Paris, $660 \mathrm{pp}$.

DESOUKY, M. M. A., 2006, Tissue distribution and subcellular localization of trace metals in the pond snail Lymnaea stagnalis with special reference to the role of lysosomal granules in metal sequestration. Aquatic Toxicology, 77: 143-152.

DEVI, C. U., K. H. RAO \& K. SHYAMASUNDARI, 1981, Observations on the histology and cytochemistry of the digestive gland in Pila virens
(Lamarck) (Mollusca: Gastropoda). Proceedings of the Indian Academy of Sciences (Animal Sciences), 90: 307-314.

DIETRICH, D. R., E. O'BRIEN, S. HOFFMANN, P. BALAGUER, J.-C. NICOLAS, W. SEINEN \& M. DEPLEDGE, 2006, Effects of BPA in snails. Environmental Health Perspectives, 114: A340-A341.

DIGIANI, M. \& M. OSTROWSKI DE NÚÑEZ, 2000, Estudios preliminares sobre el ciclo biológico de Dietziella egregia (Dietz, 1909) (Digenea: Echinostomatidae) en la provincia de Buenos Aires. P. 366, in: III Congreso Argentino de Parasitología, 1-4 Noviembre 2000, Mar del Plata.

DILLON, R. T., Jr., 2000, The ecology of freshwater molluscs. Cambridge University Press, Cambridge, UK, xii + 509 pp.

DILLON, R. T., Jr., 2002, The inheritance of golden, a shell color variant of Marisa cornuarietis. Malacological Review 31/32: 155-157.

DI PERSIA, D. \& M. RADICI DE CURA, 1973, Algunas consideraciones acerca de los organismos epibiontes desarrollados sobre Ampullariidae. Physis, 32: 309-319.

DIUPOTEX-CHONG, M., N. CAZZANIGA, A. HERNÁNDEZ-SANTOYO \& J. BETANCOURTRULE, 2004, Karyotype description of Pomacea patula catemacensis (Caenogastropoda, Ampullariidae), with an assessment of the taxonomic status of Pomacea patula. Biocell, 28: 279-285.

DIUPOTEX-CHONG, M., N. CAZZANIGA \& M. URIBE-ALCOCER, 2007, Karyological and electrophoretic differences between Pomacea flagellata and $P$. patula catemacensis (Caenogastropoda: Ampullariidae). Biocell, 31: 365-373.

DOHRN, H., 1865, List of the land and freshwater shells of the Zambesi and Lake Nyassa, Eastern tropical Africa, collected by John Kirk, M.D., F.L.S., \&c. Proceedings of the Zoological Society of London 1865: 231-234.

DORTA-CONTRERAS, A. J., M. E. MAGRANERTARRAU \& E. SÁNCHEZ-ZULUETA, 2009, Angiostrongyliasis in the Americas. Emerging Infectious Diseases, 15: 991.

DRAPARNAUD J.-P.-R., 1805, Histoire naturelle des mollusques terrestres et fluviatiles de la France, ouvrage posthume. Louis Colas, Paris.

DREON, M. S., M. V. FRASSA, M. CEOLIN, S. ITUARTE, J.-W. QIU, J. SUN, P. E. FERNÁNDEZ \& H. HERAS, 2013, Novel animal defenses against predation: a snail egg neurotoxin combining lectin and pore-forming chains that resembles plant defense and bacteria attack toxins. PLoS One, 8(5): e63782.

DREON, M. S., H. HERAS \& R. J. POLLERO, 2003, Metabolism of ovorubin, the major egg lipoprotein from the apple snail. Molecular and Cellular Biochemistry, 243: 9-14.

DREON, M. S., H. HERAS \& R. J. POLLERO, 2004a, Characterization of the major egg glycolipoproteins from the perivitellin fluid of the apple snail Pomacea canaliculata. Molecular Reproduction and Development, 68: 359-364. 
DREON, M. S., S. ITUARTE, M. CEOLIN \& H. HERAS, 2008, Global shape and pH stability of ovorubin, an oligomeric protein from the eggs of Pomacea canaliculata. FEBS Journal, 275(4522): 4530.

DREON, M. S., S. ITUARTE \& H. HERAS, 2010, The Role of the Proteinase Inhibitor Ovorubin in Apple Snail Eggs Resembles Plant Embryo Defense against Predation. PLoS One, 5(12): e15059.

DREON, M. S., S. LAVARÍAS, C. F. GARÍN, H. HERAS \& R. J. POLLERO, 2002, Synthesis, distribution, and levels of an egg lipoprotein from the apple snail Pomacea canaliculata (Mollusca: Gastropoda). Journal of Experimental Zoology, 292: 323-330.

DREON, M. S., G. SCHINELLA, H. HERAS \& R. J. POLLERO, 2004b, Antioxidant defense system in the apple snail eggs, the role of ovorubin. Archives of Biochemistry and Biophysics, 422: 1-8.

EAMSOBHANA, P., A. YOOLEK \& H.-S. YONG, 2010, Effect of Thai 'koi-hoi' food flavoring on the viability and infectivity of the third-stage larvae of Angiostrongylus cantonensis (Nematoda: Angiostrongylidae). Acta Tropica, 113: 245-247.

EFSA [European Food Safety Authority, Panel on Plant Health], 2013, Assessment of the potential establishment of the apple snail in the EU. EFSA Journal 2013, 11(12): 3487, 50 pp.

ESTEBENET, A. L., 1995, Food and feeding in Pomacea canaliculata (Gastropoda: Ampullariidae). The Veliger, 38: 277-283.

ESTEBENET, A. L., 1998, Allometric growth and insight on sexual dimorphism in Pomacea canaliculata (Gastropoda: Ampullariidae). Malacologia, 39: 207-213.

ESTEBENET, A. L. \& N. J. CAZZANIGA, 1992, Growth and demography of Pomacea canaliculata (Gastropoda: Ampullariidae) under laboratory conditions. Malacological Review, 25:1-12.

ESTEBENET, A. L. \& N. J. CAZZANIGA, 1993, Egg variability and the reproductive strategy of Pomacea canaliculata (Gastropoda: Ampullariidae). Apex, 8: 129-138.

ESTEBENET, A. L. \& N. J. CAZZANIGA, 1998, Sex-related differential growth in Pomacea canaliculata (Gastropoda: Ampullaridae). Journal of Molluscan Studies, 64: 119-123.

ESTEBENET, A. L. \& P. R. MARTíN, 2002, Pomacea canaliculata (Gastropoda: Ampullariidae): life-history traits and their plasticity. Biocell, 26: 83-89.

ESTEBENET, A. L. \& P. R. MARTíN, 2003, Shell interpopulation variation and its origin in Pomacea canaliculata (Gastropoda: Ampullariidae) from southern Pampas, Argentina. Journal of Molluscan Studies, 69: 301-310.

ESTEBENET, A. L., P. R. MARTÍN \& S. BURELA 2006, Conchological variation in Pomacea canaliculata and other South American Ampullariidae (Caenogastropoda, Architaenioglossa). Biocell, 30: 329-335.

ESTOY, G. F. Jr. Y YUSA, T. WADA, H. SAKURAI \& K. TSUCHIDA, 2002a, Size and age at first copulation and spawning of the apple snail, Pomacea canaliculata (Gastropoda: Ampullariidae). Applied Entomology and Zoology, 37: 199-205.

ESTOY, G. F. Jr., Y. YUSA, T. WADA, H. SAKURAI \& K. TSUCHIDA, 2002b, Effects of food availability and age on the reproductive effort of the apple snail, Pomacea canaliculata (Lamarck) (Gastropoda: Ampullariidae). Applied Entomology and Zoology, 37: 543-550.

EVELAND, L. K. \& M. A. HASEEB, 2003, Echinostoma species. Pp. 571-579, in: M. D. MıLIOTIS \& J. W. BIER, eds., International handbook of foodborne pathogens. Marcel Dekker, Inc., New York and Basel, [vi] +xi + [i] + 839 pp.

EZEMONYE, L., V. ENOBAKHARE \& I. ILECHIE, 2006, Bioaccumulation of heavy metals $(\mathrm{Cu}, \mathrm{Zn}$, $\mathrm{Fe}$ ) in freshwater snail (Pila ovata; Oliver [sic] 1804) from Ikpoba River of Southern Nigeria. Journal of Aquatic Sciences, 21: 23-28.

FAN, P., C. WU, C. YEN \& P. HUANG, 2000, Survival of Pomacea species out of water kept in $25^{\circ} \mathrm{C}$ laboratory condition. Bulletin of Malacology, Taiwan, ROC, 24: 1-6.

FANG, L., P. K. WONG, L. LIN, C. LAN \& J.-W. QIU, 2010, Impact of invasive apple snails in Hong Kong on wetland macrophytes, nutrients, phytoplankton and filamentous algae. Freshwater Biology, 55: 1191-1204.

FARACO, F., I. L. VEITENHEIMER-MENDES \& E. BORGES, 2002, Felipponea neritiformis (Gastropoda, Ampullariidae): concha, rádula, complexo peniano e primeiras observações sobre comportamento reprodutivo. Biociências, 10: 65-78.

FELLERHOFF, C., 2002. Feeding and growth of apple snail Pomacea lineata [sic] in the Pantanal wetland, Brazil - a stable isotope approach. Isotopes in Environmental and Health Studies, 38: 227-243.

FERNANDO, W., 1931, The development of the kidney in Ampullaria (Pila) gigas. Proceedings of the Zoological Society of London, 62: 745-750.

FISCHER, J.-C., 1963, Les gastéropodes du "continental intercalaire" du Sahara. In: D. MoNGIN ongin \& J.-C. FISCHER, Les mollusques du "continental intercalaire" (Mésozoïque) du Sahara central. Mémoires de la Société Géologique de France (Nouvelle Série), 42(96): 41-49, pls. 7-8.

FORBES, V. E., J. AUFDERHEIDE, R. WARBRITTON, N. VAN DER HOEVEN \& N. CASPERS, 2007a, Does bisphenol A induce superfeminization in Marisa cornuarietis? Part II: toxicity test results and requirements for statistical power analyses. Ecotoxicology and Environmental Safety, 66: 319-325.

FORBES, V. E., H. SELCK, A. PALMQVIST, J. AUFDERHEIDE, R. WARBRITTON, N. POUNDS, R. THOMPSON, N. VAN DER HOEVEN \& N. CASPERS, 2007b, Does bisphenol A induce superfeminization in Marisa cornuarietis? Part I: intra- and inter-laboratory variability in test endpoints. Ecotoxicology and Environmental Safety, 66: 309-318. 
FORBES, V. E., R. WARBRITTON, J. AUFDERHEIDE, N. VAN DER HOEVEN \& N. CASPERS, 2008, Effects of bisphenol A on fecundity, egg hatchability, and juvenile growth of Marisa cornuarietis. Environmental Toxicology and Chemistry, 27: 2332-2340.

FRAKES, R. A., T. A. BARGAR \& E. A. BOUGHNER, 2008, Sediment copper bioavailability to freshwater snails in South Florida: risk implications for the Everglade snail kite (Rostrhamus sociabilis plumbeus). Ecotoxicology, 17: 598-604.

FRANCHINI, A. \& E. OTTAVIANI, 2000, Repair of molluscan tissue injury: role of PDGF and TGF-b1. Tissue and Cell, 32: 312-321.

FRASSA, M. V., M. CEOLÍN, M. S. DREON \& H. HERAS, 2010, Structure and stability of the neurotoxin PV2 from the eggs of the apple snail Pomacea canaliculata. Biochimica et Biophysica Acta - Proteins and Proteomics, 1804: 1492-1499.

FREIBURG, M. W. \& D. H. HAZELWOOD, 1977, Oxygen consumption of two amphibious snails: Pomacea paludosa and Marisa cornuarietis (Prosobranchia: Ampullariidae). Malacologia, 16: 541-548.

FRETTER, V. \& A. GRAHAM, 1994, British prosobranch molluscs: their functional anatomy and ecology. Ray Society, London, xix + $820 \mathrm{pp}$

GAMARRA-LUQUES, C., M. GIRAUD-BILLOUD \& A. CASTRO-VAZQUEZ, 2013, Reproductive organogenesis in the apple snail Pomacea canaliculata (Lamarck, 1822), with reference to the effects of xenobiotics. Journal of Molluscan Studies, 79: 147-162.

GAMARRA-LUQUES, C., I. A. VEGA, E. KOCH \& A. CASTRO-VAZQUEZ, 2004, Intrahost distribution and transmission of a new species of cyclopoid copepod endosymbiotic to a freshwater snail, Pomacea canaliculata (Caenogastropoda, Ampullariidae), from Argentina. Biocell, 28: 155-164.

GAMARRA-LUQUES, C., B. C. WINIK, I. A. VEGA, E. A. ALBRECHT, N. M. CATALÁN \& A. CASTRO-VAZQUEZ, 2006, An integrative view to structure, function, ontogeny and phylogenetical significance of the male genital system in Pomacea canaliculata (Caenogastropoda, Ampullariidae). Biocell, 30: 345-357.

GARIN, C. F., H. HERAS \& R. J. POLLERO, 1996, Lipoproteins of the egg perivitellin fluid of Pomacea canaliculata snails (Mollusca: Gastropoda). Journal of Experimental Zoology, 276: 307-314.

GASCÓN, A., 1975, Dos ciliados del género Parasicuophora parásitos de Pomacea canaliculata. Revista de Biología del Uruguay, 3: 111-125.

GIRAUD-BILLOUD, M., M. ABUD, J. CUETO, I. VEGA\&A. CASTRO-VAZQUEZ, 2011, Uric acid deposits and estivation in the invasive applesnail, Pomacea canaliculata. Comparative Biochemistry and Physiology, A, 158: 506-512.

GIRAUD-BILLOUD, M., C. GAMARRA-LUQUES \& A. CASTRO-VAZQUEZ, 2013a, Functional anatomy of male copulatory organs of Pomacea canaliculata (Caenogastropoda, Ampullariidae). Zoomorphology, 132: 129-143.
GIRAUD-BILLOUD, M., E. KOCH, I. A. VEGA, C. GAMARRA-LUQUES \&A. CASTRO-VAZQUEZ, 2008, Urate cells and tissues in the South American apple-snail Pomacea canaliculata. Journal of Molluscan Studies, 74: 259-266.

GIRAUD-BILLOUD, M., I. A. VEGA, M. E. RINALDI TOSI, M. A. ABUD, M. L. CALDERÓN \& A. CASTRO-VAZQUEZ, 2013b, Antioxidant and molecular chaperone defenses during estivation and arousal in the South American apple-snail Pomacea canaliculata. Journal of Experimental Biology, 216: 614-622.

GIRAUD-BILLOUD, M., I. A. VEGA, R. G. WUILLOUD, M. E. CLEMENT \& A. CASTRO-VAZQUEZ, 2013c, Imposex and novel mechanisms of reproductive failure induced by tributyltin (TBT) in the freshwater snail Pomacea canaliculata. Environmental Toxicology and Chemistry, 32: 2365-2371.

GLASS, N. H. \& P. C. DARBY, 2009, The effect of calcium and $\mathrm{pH}$ on Florida apple snail, Pomacea paludosa (Gastropoda: Ampullariidae), shell growth and crush weight. Aquatic Ecology, 43: 1085-1093.

GODOY, M. S., A. CASTRO-VAZQUEZ \& I. A. VEGA, 2013, Endosymbiotic and host proteases in the digestive tract of the invasive snail Pomacea canaliculata: diversity, origin and characterization. PLoS One, 8: e66689.

GORNI, G. R. \& R. G. ALVES, 2006, Naididae (Annelida, Oligochaeta) associated with Pomacea bridgesii (Reeve)(Gastropoda, Ampullaridae). Revista Brasileira de Zoologia, 23: 1059-1061.

GOULD, A. A., 1859, Descriptions of new species of shells. Proceedings of the Boston Society of Natural History, 7: 40-45.

GRACZYK, T. K. \& B. FRIED, 1998, Echinostomiasis: a common but forgotten food-borne disease. American Journal of Tropical Medicine and Hygiene, 58: 501-504.

GRAEFF-TEIXEIRA, C., A. C. A. SILVA \& K. YOSHIMURA, 2009, Update on eosinophilic meningoencephalitis and its clinical relevance. Clinical Microbiology Reviews, 22: 322-348.

GRANTHAM, Ö., D. L. MOORHEAD \& M. R. WILLIG, 1993, Feeding preference of an aquatic gastropod, Marisa cornuarietis: effects of pre-exposure. Journal of the North American Benthological Society, 12: 431-437.

GRÜN, F., H. WATANABE, Z. ZAMANIAN, L. MAEDA, K. ARIMA, R. CHUBACHA, D. M. GARDINER, J. KANNO, T. IGUCHI \& B. BLUMBERG, 2006, Endocrine disrupting organotin compounds are potent inducers of adipogenesis in vertebrates. Molecular Endocrinology, 20: 2141-2155.

GUIMARÃES, C. T., 1981a, Algumas observações de laboratória sobre biologia e ecologia de Pomacea haustrum (Reeve, 1856). Memorias do Instituto Oswaldo Cruz, 76: 33-46.

GUIMARÃES, C. T., 1981b, Algumas observações de campo sobre biologia e ecologia de Pomacea haustrum (Reeve, 1856) (Mollusca, Pilidae). Memórias do Instituto Oswaldo Cruz, 76: 343-351. 
HÄGLER, K., 1923, Anatomie von Pachylabra (Ampullaria) cinerea Reeve: I. Teil. Mit Einschluss einer kurzen Besprechung der wichstigen Literatur über die Ampullariidae. Acta Zoologica, 4: 313-424.

HALWART, M., 1994, The golden apple snail Pomacea canaliculata in Asian rice farming systems: present impact and future threat. International Journal of Pest Management, 40: 199-206.

HAMLI, H., M. H. IDRIS, M. K. ABU HENA, S. K. WONG \& A. ARSHAD, 2013, Checklist and habitat descriptions of edible gastropods from Sarawak, Malaysia. Journal of Fisheries and Aquatic Science, 8: 412-418.

HAMANN, M. I., 1992, Catadiscus pomaceae sp. n. (Trematoda, Paramphistomidae) from Pomacea canaliculata (Lamarck, 1801 [sic]) (Prosobranchia, Ampullariidae). Memórias do Instituto Oswaldo Cruz, 87: 9-14.

HANIFFA, M. A., 1978, Energy loss in an aestivating population of the tropical snail Pila Globosa. Hydrobiologia, 61: 169-182.

HANIFFA, M. A., 1980, Studies on life span, growth increments and energy budget of the freshwater snail Pila globosa (Swainson) in an artificial pond. Proceedings of the Indian Academy of Sciences (Animal Sciences), 89: 275-286.

HANIFFA, M. A. \& T. T. PANDIAN, 1974, Effects of body weight on feeding and radula size in the freshwater snail Pila globosa. The Veliger 16: 415-418.

HANNING, G. W., 1979, Aspects of reproduction in Pomacea paludosa (Mesogastropoda: Pilidae). MS thesis, Florida State University, Tallahassee, Florida, U.S.A.

HANNING, G. W. \& W. S. LEEDOM, 1978, Schistosome dermatitis from Pomacea paludosa (Say) (Prosobranchia: Pilidae). The Nautilus, 92: 105-106.

HARASEWYCH, M. G., S. L. ADAMKEWICZ, M. PLASSMEYER \& P. M. GILLEVET, 1998 , Phylogenetic relationships of the lower Caenogastropoda (Mollusca, Gastropoda, Architaenioglossa, Campaniloidea, Cerithiodea) as determined by partial 18S rDNA sequences. Zoologica Scripta, 27: 361-372.

HAYES, K. A., 2009, Evolution, molecular systematics and invasion biology of Ampullariidae. Ph.D. Dissertation, University of Hawaii, Honolulu.

HAYES, K. A., R. H. COWIE, A. JØRGENSEN, R. SCHULTHEIß, C. ALBRECHT \& S. C. THIENGO, 2009a, Molluscan models in evolutionary biology: apple snails (Gastropoda: Ampullariidae) as a system for addressing fundamental questions. American Malacological Bulletin, 27: 47-58.

HAYES, K. A., R. H. COWIE \& S. C. THIENGO, 2009b, A global phylogeny of apple snails: Gondwanan origin, generic relationships and the influence of outgroup choice (Caenogastropoda: Ampullariidae). Biological Journal of the Linnean Society, 98: 61-76.

HAYES, K. A., R. H. COWIE, S. C. THIENGO \& E. E. STRONG, 2012, Comparing apples with apples: clarifying the identities of two highly invasive Neotropical Ampullariidae (Caenogastropoda). Zoological Journal of the Linnean Society, 166: 723-753.

HAYES, K. A., R. C. JOSHI, S. C. THIENGO \& R. H. COWIE, 2008, Out of South America: multiple origins of non native apple snails in Asia. Diversity and Distributions, 14: 701-712.

HEILER, K. C. M., R. SCHULTHEIß, T. GEERTZ \& C. ALBRECHT, 2007, Caught in the act: Insights into the sex life of Lanistes ovum (Gastopoda: Ampullariidae). P. 94, in: K. JoRDAENS, N. Van Houtte, J. Van Goethem \& T. Backeljau, eds., World Congress of Malacology. Antwerp, Belgium, 15-20 July 2007. Abstracts, Unitas Malacologica, Antwerp, Ixxix + 298 pp.

HEILER, K. C. M., P. V. VON OHEIMB, K. EKSCHMITT \& C. ALBRECHT, 2008, Studies on the temperature dependence of activity and on the diurnal activity rhythm of the invasive Pomacea canaliculata (Gastropoda: Ampullariidae). Mollusca, 26: 73-81.

HERAS, H., M. S. DREON, S. ITUARTE \& R. J. POLLERO, 2007, Egg carotenoproteins in neotropical Ampullariidae (Gastropoda: Arquitaenioglossa). Comparative Biochemistry and Physiology C, 146: 158-167.

HERAS, H., M. V. FRASSA, P. E. FERNÁNDEZ, C. M. GALOSI, E. J. GIMENO \& M. S. DREON, 2008 , First egg protein with a neurotoxic effect on mice. Toxicon, 52: 481-488.

HERAS, H., C. F. GARÍN \& R. J. POLLERO, 1998, Biochemical composition and energy sources during embryo development and in early juveniles of the snail Pomacea canaliculata (Mollusca: Gastropoda). Journal of Experimental Zoology, 280: 375-383.

HERMES-LIMA, M., J. STOREY \& K. STOREY, 1998, Antioxidant defenses and metabolic depression. The hypothesis of preparation for oxidative stress in land snails. Comparative Biochemistry and Physiology B, 120: 437-448.

HERMES-LIMA, M. \& T. ZENTENO-SAVIN, 2002, Animal response to drastic changes in oxygen availability and physiological oxidative stress. Comparative Biochemistry and Physiology C, 133: $537-556$

HIRATA, K., Y. ASO \& M. ISHIGURO, 1998a, Purification and some properties of $\beta$-mannosidase, $\beta-N$-acetylglucosaminidase, and $\beta$-galactosidase from apple snails (Pomacea canaliculata). Journal of the Faculty of Agriculture, Kyushu University, 42: 463-472.

HIRATA, K., Y. ASO \& M. ISHIGURO, 1998b, Properties of a-mannosidase partially purified from the apple snail, Pomacea canaliculata. Bioscience, Biotechnology, and Biochemistry, 62: 2242-2245.

HIRATA, K., Y. ASO, S. YASUDA \& M. ISHIGURO, 1998c, Purification of Pomacea canaliculata $\alpha$-fucosidase isoforms with different thermostabilities. Bioscience, Biotechnology, and Biochemistry, 62: 807-810.

HIRATA, K., Y. NAKAHARA, Y. KIMURA \& G. FUNATSU, 1996, Purification and some properties of a $\beta$-xylosidase and an $\alpha$-fucosidase from apple snails (Pomacea canaliculata). 
Bioscience, Biotechnology, and Biochemistry, 59: 249-254.

HO, J. S., 1994, Origin and evolution of the parasitic cyclopoid copepods. International Journal for Parasitology, 24: 1293-1300.

HO, J. S. \& V. E. THATCHER, 1989, A new family of cyclopoid copepods (Ozmanidae) parasitic in the hemocoel of a snail from the Brazilian Amazon. Journal of Natural History, 23: 903-911.

HOANG, T. C., E. C. ROGEVICH, G. M. RAND \& R. A. FRAKES, 2008, Copper uptake and depuration by juvenile and adult Florida apple snails (Pomacea paludosa). Ecotoxicology, 17: 605-615.

HODGSON, A. N., 1999, Paraspermatozoa. Pp. 656-668, in: E. KNOBIL \& J. D. NeILL, eds., Encyclopedia of Reproduction, Vol. 3. Academic Press, San Diego, California, U.S.A., xxvi + 1072 pp.

HOLLINGSWORTH, R. C. \& R. H. COWIE, 2006, Apple snails as disease vectors. Pp. 121-132 in: R. Joshi \& L. S. Sebastian, eds., Global advances in ecology and management of golden apple snails. Philippine Rice Research Institute, Muñoz, Nueva Ecija, Philippines, $x+588$ pp.

HORN, K. C., S. D. JOHNSON, K. M. BOLES, A. MOORE, E. SIEMANN \& C. A. GABLER, 2008 Factors affecting hatching success of golden apple snail eggs: effects of water immersion and cannibalism. Wetlands, 28: 544-549.

HURDLE, M. T., 1973, Life history studies and habitat requirements of the apple snail at Lake Woodruff National Wildlife Refuge. Proceedings of the Twenty-seventh Annual Conference. Southeastern Association of Game and Fish Commissioners, 27: 215-224.

HYLTON SCOTT, M. I., 1934, Sobre el desarrollo embrionario de Ampullaria canaliculata. Revista del Museo de La Plata, 34: 373-385.

HYLTON SCOTT, M. I., 1958, Estudio morfológico y taxonómico de los ampulláridos de la República Argentina. Revista del Museo Argentino de Ciencias Naturales 'Bernardino Rivadavia', 3: 233-333.

HYMAN, L., 1967, The invertebrates, Vol. 6: Mollusca I. McGraw-Hill, New York, 792 pp.

IBRAHIM, M. M., 2007, Prevalence and intensity of Angiostrongylus cantonensis in freshwater snails in relation to some ecological and biological factors. Parasite, 14: 61-70.

ICHINOSE, K., 2002, Influence of age and body size on alarm responses in a freshwater snail Pomacea canaliculata. Journal of Chemical Ecology, 28: 2017-2028.

ICHINOSE, K., M. TOCHIHARA, T. WADA, N. SUGUIURA \& Y. YUSA, 2002, Influence of common carp on apple snail in a rice field evaluated by a predator-prey logistic model. International Journal of Pest Management, 48: 133-138.

ICHINOSE, K., T. WADA, Y. YUSA \& T. KUBOTA, 2000, Influence of habitat differences brought about by environmental changes on the densities of adults and eggs of Pomacea canaliculata. Proceedings of the Association for Plant Protection of Kyushu, 46: 78-84.

ICHINOSE, K., Y. YUSA \& K. YOSHIDA, 2003, Alarm response of hatchlings of the apple snail, Pomacea canaliculata (Gastropoda: Ampullarii- dae), to aqueous extracts of other individuals. Ecological Research, 18: 213-219.

ICZN [International Commission on Zoological Nomenclature], 1999, Opinion 1913. Pila Röding, 1798 and Pomacea Perry, 1810 (Mollusca, Gastropoda): placed on the Official List, and Ampullariidae Gray, 1824: confirmed as the nomenclaturally valid synonym of Pilidae Preston, 1915. Bulletin of Zoological Nomenclature, 56: 74-76.

IMJONGJIRAK, C. P. AMPARYUP \& S. SITTIP. RANEED, 2008, Cloning, genomic organization and expression of two glycosyl hydrolase family 10 (GHF10) genes from golden apple snail (Pomacea canaliculata). DNA Sequence, 19: 224-236.

ITO, K., 2002, Environmental factors influencing overwintering success of the golden apple snail, Pomacea canaliculata (Gastropoda: Ampullariidae), in the northernmost population of Japan. Applied Entomology and Zoology, 37: 655-661.

ITUARTE, S., M. S. DREON, M. CEOLIN \& H. HERAS, 2012, Agglutinating activity and structural characterization of scalarin, the major egg protein of the snail Pomacea scalaris (d'Orbigny, 1832). PLoS One, 7(11): e50115.

ITUARTE, S., M. S. DREON, M. Y. PASQUEVICH, P. E. FERNANDEZ \& H. HERAS, 2010, Carbohydrates and glycoforms of the major egg perivitellins from Pomacea apple snails (Architaenioglossa: Ampullariidae). Comparative Biochemistry and Physiology B, 157: 66-72.

ITUARTE, S., M. S. DREON, R. J. POLLERO \& H. HERAS, 2008, Isolation and partial characterization of a new lipo-glyco-carotenoprotein from Pomacea scalaris (Gastropoda: Ampullariidae). Molecular Reproduction and Development, 75 : 1441-1448.

JANER, G., J. C. NAVARRO \& C. PORTE, 2007, Exposure to TBT increases accumulation of lipids and alters fatty acid homeostasis in the ramshorn snail Marisa cornuarietis. Comparative Biochemistry and Physiology C, 146: 368-374.

JEONG, K. H., K. J. LIE \& D. HEYNEMAN, 1983, The ultrastructure of the amoebocyte-producing organ in Biomphalaria glabrata. Developmental and Comparative Immunology, 7: 217-228.

JØRGENSEN, A., T. K. KRISTENSEN \& H. MADSEN, 2008, A molecular phylogeny of apple snails (Gastropoda, Caenogastropoda, Ampullariidae) with an emphasis on African species. Zoologica Scripta, 37: 245-252.

JOSHI, R. C., E. C. MARTIN, T. WADA \& L. S. SEBASTIAN, 2006, Role of golden apple snails in organic rice cultivation and weed management. Pp. 483-488, in: R. C. JosHI \& L. S. SEBASTIAN, eds., Global advances in ecology and management of golden apple snails. Philippine Rice Research Institute, Muñoz, Nueva Ecija, Philippines, $x+588$ pp.

JOSHI, R. C. \& L. A. SEBASTIAN, eds., 2006, Global advances in ecology and management of golden apple snails. Philippine Rice Research Institute, Muñoz, Nueva Ecija, Philippines, x + $588 \mathrm{pp}$. 
KANG, J.-H., D. ASAI \& Y. KATAYAMA, 2007 Bisphenol $A$ in the aquatic environment and its endocrine-disruptive effects on aquatic organisms. Critical Reviews in Toxicology, 37: 607-625.

KARATAYEV, A. Y., L. E. BURLAKOVA, V. A. KARATAYEV \& D. K. PADILLA, 2009, Introduction, distribution, spread, and impacts of exotic freshwater gastropods in Texas. Hydrobiologia, 619: 181-194.

KARRAKER, N. E. \& D. DUDGEON, 2014, Invasive apple snails (Pomacea canaliculata) are predators of amphibians in south China. Biological Invasions, 16: 1785-1789.

KARUNARATNE, L. B., P. C. DARBY \& R. E. BENNETTS, 2006, The effects of wetland habitat structure on Florida apple snail density. Wetlands, 26: 1143-1150.

KAWANO, T., L. SIMÖES \& F. CORREA, 1990, Chromosomes of Pomacea sp. (Perry, 1811) (Mesogastropoda, Mollusca). Revista Brasileira de Genética, 13: 675-685.

KEAWJAM, R. S., 1986, The apple snails of Thailand: distribution, habitats and shell morphology. Malacological Review, 19: 61-81.

KEAWJAM, R. S., 1987, The apple snails of Thailand: aspects of comparative anatomy. Malacological Review, 20: 69-89.

KEAWJAM, R. S., P. POONSWAD, E. S. UPATHAM \& S. BANPAVICHIT, 1993, Natural parasitic infection of the golden apple snail, Pomacea canaliculata. Southeast Asian Journal of Tropical Medicine and Public Health, 24: 170-177.

KIM, J. R., K. A. HAYES, N. W. YEUNG \& R. H. COWIE, 2014, Diverse gastropod hosts of Angiostrongylus cantonensis, the rat lungworm, globally and with a focus on the Hawaiian Islands. PLoS ONE, 9(5): e940969.

$\mathrm{KOCH}, \mathrm{E} ., 2008$, Transmisión de un endocianobionte de Pomacea canaliculata (Caenogastropoda, Ampullariidae): dónde, cuándo y cómo. Ph.D. Thesis, Universidad Nacional de Cuyo, Mendoza.

$\mathrm{KOCH}$, E., M. LOZADA, H. DIONISI \& A. CASTRO-VAZQUEZ, 2014, Uric acid-degrading bacteria in the gut of the apple snail Pomacea canaliculata and their possible symbiotic significance. Symbiosis, 63: 149-155.

$\mathrm{KOCH}, \mathrm{E}$., I. A. VEGA, E. A. ALBRECHT, H. ORTEGA \& A. CASTRO-VAZQUEZ, 2006, A light and electron microscopic study of pigmented corpuscles in the midgut gland and feces of Pomacea canaliculata (Caenogastropoda: Ampullariidae). The Veliger, 48: 17-25.

$\mathrm{KOCH}, \mathrm{E} ., \mathrm{B}$. WINIK \& A. CASTRO-VAZQUEZ, 2009, Development beyond the gastrula stage and digestive organogenesis in the apple-snail Pomacea canaliculata (Architaenioglossa, Ampullariidae). Biocell, 33: 49-65.

KÜSTER, H. C., 1860 [1843-1860], Die Gattungen Buccinum, Purpura, Concholepas und Monoceros. In: H. C. Küster, ed., Systematisches Conchylien-Cabinet von Martini und Chemnitz. Dritten Bandes erste Abteilung. Erster Theil. Bauer \& Raspe, Nurnberg, 229 pp., 43 pls.
KWONG, K.-L., R. K. Y. CHAN \& J.-W. QIU, 2009 , The potential of the invasive snail Pomacea canaliculata as a predator of various life-stages of five species of freshwater snails. Malacologia, 51: 343-356.

KWONG, K. L., D. DUDGEON, P. K. WONG \& J.-W. QIU, 2010, Secondary production and diet of an invasive snail in freshwater wetlands: implications for resource utilization and competition. Biological Invasions, 12: 1153-1164.

KWONG, K.-L., P.-K. WONG, S. S. S. LAU \& J.-W. QIU, 2008, Determinants of the distribution of apple snails in Hong Kong two decades after their initial invasion. Malacologia, 50: 293-302.

KYLE, C. H., A. W. KROPF \& R. L. BURKS, 2011, Prime waterfront real estate: apple snails choose wild taro for oviposition sites. Current Zoology, 57: 630-641.

KYLE, C. H., A. L. PLANTZ, T. SHELTON \& R. L. BURKS, 2013, Count your eggs before they invade: identifying and quantifying egg clutches of two invasive apple snail species (Pomacea). PLOS ONE, 8(10): e77736.

LACH, L., D. K. BRITTON, R. J. RUNDELL \& R. H. COWIE, 2000, Food preference and reproductive plasticity in an invasive freshwater snail. Biological Invasions, 2: 279-288.

LAL, M. B. \& B. B. SAXENA, 1952, Uricotelism in the common Indian apple-snail, Pila globosa (Swainson). Nature, 170: 1024

LAM, P. K. S., 1994, Intraspecific life-history variation in Radix plicatulus (Gastropoda: Pulmonata: Lymnaeidae). Journal of Zoology, 232: 435-446.

LAMARCK, [J. B. P. A. de M.] de, 1822, Histoire naturelle des animaux sans vertèbres..., Tome sixième, 2me partie. L'auteur, Paris, $232 \mathrm{pp}$.

LANZER, R. M. \& A. SCHAFER, 1985, Padrões de distribuição de moluscos dulceaquícolas nas lagoas costeiras do Sul do Brasil. Revista Brasileira de Biologia, 45: 535-545.

LAPORTA-FERREIRA, I. L. \& M. G. SALOMÃO, 2004, Reptilian predators of terrestrial gastropods. Pp. 427-481, in: G. M. BARKER, ed., Natural enemies of terrestrial molluscs. CABI, Wallingford, $x+644$ pp.

LEA, I., 1856, Description of thirteen new species of exotic Peristomata. Proceedings of the Academy of Natural Sciences of Philadelphia, 8: 109-111.

LEE, R. E., Jr., 1991, Principles of insect low temperature tolerance. Pp. 131-148, in: R. E. LEE, JR. \& D. L. DenLINGER, eds., Insects at low temperature. Chapman \& Hall, New York, $\mathrm{x}+$ $513 \mathrm{pp}$.

LEEDOM, W. S. \& R. B. SHORT, 1981, Cercaria pomaceae sp. n., a dermatitis-producing schistosome cercaria from Pomacea paludosa, the Florida apple snail. Journal of Parasitology, 67: 257-261.

LI, Y. H., R. GUO, Q. Y. YIN, M. DING, S. L. ZHANG, G. J. XU \& F. K. ZHAO, 2005, Purification and characterization of two endo-beta-1,4glucanases from Mollusca, Ampullaria crossean [sic]. Acta Biochimica et Biophysica Sinica, 37: 702-708. 
LIE, K. J., D. HEYNEMAN \& P. YAU, 1975, The origin of amoebocytes in Biomphalaria glabrata. Journal of Parasitology, 63: 574-576.

LINNAEUS, C., 1758, Systema naturae per regna tria naturae, secundum classes, ordines, genera, species, cum caracteribus, differentiis, synonymis, locis. Tomus I. Editio decima, reformata. L. Salvii, Holmiae [= Stockholm], 824 + iii pp.

LITTLE, C., 1968, Aestivation and ionic regulation in two species of Pomacea (Gastropoda, Prosobranchia). Journal of Experimental Biology, 48: 569-585.

LIU, J., Y. HE, J. TAN, C. XU, L. ZHONG, Z. WANG \& Q. LIAO, 2012, Characteristics of Pomacea canaliculata reproduction under natural conditions. Chinese Journal of Applied Ecology, 23: 559-565.

LIU, W.-H., Y.-W. CHIU, D.-J. HUANG, M.-Y. LIU, C.-C. LEE \& L.-L. LIU, 2006, Imposex in the golden apple snail Pomacea canaliculata in Taiwan. Science of the Total Environment, 371: 138-143.

LODGE, D. M., 1991, Herbivory on freshwater macrophytes. Aquatic Botany, 41: 195-224.

LÓPEZ, M. A., C. R. ALTABA, K. B. ANDREE \& V. LÓPEZ, 2010, First invasion of the apple snail Pomacea insularum in Europe. Tentacle, 18: 26-28.

LOUDA, S. M. \& K. R. McKAYE, 1982, Diurnal movements in populations of the prosobranch Lanistes nyassanus at Cape Maclear, Lake Malawi, Africa. Malacologia, 23: 13-21.

LUM-KONG, A. \& J. S. KENNY, 1989, The reproductive biology of the ampullariid snail Pomacea urceus (Müller). Journal of Molluscan Studies, 55: 53-65

LUTFY, R. G. \& E. S. DEMIAN, 1965, Studies on the chromosome numbers in the Ampullariidae (Gastropoda, Prosobranchiata). Proceedings of the Egyptian Academy of Sciences, 18: 34-49.

LUTFY, R. G. \& E. S. DEMIAN, 1967, The histology of the alimentary system of Marisa cornuarietis (Mesogastropoda: Ampullariidae). Malacologia, 5: 375-422.

LV, S., Y. ZHANG, H.-X. LIU, L. HU, K. YANG, STEINMANN, Z. CHEN, L.-Y. WANG, J. UTZINGER \& X.-N. ZHOU, 2009a, Invasive snails and an emerging infectious disease: results from the first national survey on Angiostrongylus cantonensis in China. PLoS Neglected Tropical Diseases, 3: e368.

LV, S., Y. ZHANG, H. LIU, C. ZHANG, P. STEINMANN, X. ZHOU \& J. UTZINGER, 2009b, Angiostrongylus cantonensis: morphological and behavioral investigation within the freshwater snail Pomacea canaliculata. Parasitology Research, 104: 1351-1359.

LV, S., Y. ZHANG, P. STEINMANN \& X.-N. ZHOU, 2008, Emerging angiostrongyliasis in mainland China. Emerging Infectious Diseases, 14: 161-164

LV, S., Y. ZHANG, P. STEINMANN, G.-J. YANG, K. YANG, X.-N. ZHOU \& J. UTZINGER, 2011 The emergence of angiostrongyliasis in the People's Republic of China: the interplay between invasive snails, climate change and transmission dynamics. Freshwater Biology, 56: 717-734

LV, S., X.-N. ZHOU, Y. ZHANG, H.-X. LIU, D. ZHU, W.-G. YIN, P. STEINMANN, X.-H. WANG \& T.W. JIA, 2006, The effect of temperature on the development of Angiostrongylus cantonensis (Chen 1935) in Pomacea canaliculata (Lamarck 1822). Parasitology Research, 99: 583-587.

MAHILINI, H. \& A. RAJENDRAN, 2008, Categorization of hemocytes of three gastropod species Trachea vittata (Muller) [sic], Pila globosa (Swainson) and Indoplanorbis exustus (Dehays) [sic]. Journal of Invertebrate Pathology, 97: 20-26.

MALTCHIK, L., C. STENERT, C. B. KOTZIAN \& D. PEREIRA, 2010, Responses of freshwater molluscs to environmental factors in southern Brazil wetlands. Brazilian Journal of Biology, 70: 473-482.

MAPELLI, F. J. \& M. J. KITTLEIN, 2011, Prey selection by the snail kite (Rostrhamus sociabilis) in permanent and temporary wetlands of central Argentina. Ornitologia Neotropical, 22: 281-293.

MARTELLO, A. R., C. B. KOTZIAN \& M. G. SIMÕES, 2006, Quantitative fidelity of recent freshwater mollusk assemblages from the Touro Passo River, Rio Grande do Sul, Brazil. Iheringia Série Zoologia, 96: 453-465.

MARTÍN, P. R. \& C. G. DE FRANCESCO, 2006, Fossil record of Pomacea (Caenogastropoda: Ampullariidae) in Argentina and its paleoenvironmental implications. Biocell, 30: 337-343.

MARTÍN, P. R. \& A. L. ESTEBENET, 2002, Interpopulation variation of life-history traits in Pomacea canaliculata (Gastropoda: Ampullariidae) in southwestern Buenos Aires Province, Argentina. Malacologia, 44: 153-163.

MARTÍN, P. R., A. ESTEBENET \& S. BURELA, 2005, Factors affecting the distribution and abundance of the commensal Temnocephala iheringi (Platyhelminthes: Temnocephalidae) among the southernmost populations of the apple snail Pomacea canaliculata (Mollusca: Ampullariidae). Hydrobiologia, 545: 45-53.

MARTÍN, P. R., A. ESTEBENET \& N. CAZZANIGA, 2001, Factors affecting the distribution of Pomacea canaliculata (Gastropoda: Ampullariidae) along its southernmost natural limit. Malacologia, 43: 13-24.

MARTíN, S. M., 1984, Estudio del complejo penial de Asolene platae (Maton) (Mollusca Gasteropoda). Neotropica. 30: 107-110.

MARTÍN, S. M., 1986, Ciclo reproductivo de Ampullaria canaliculata (Gastropoda: Ampullariidae) en el área rioplatense. Neotropica, 32: 171-181.

MARTÍN, S. M., 1993, Características poblacionales de Ampullaria scalaris d'Orbigny, 1835 (Mollusca, Gastropoda, Ampullariidae) en las Canteras de Los Talas (Berisso, Buenos Aires). Studies on Neotropical Fauna and Environment, 28: 223-231.

MARTINEZ, S. \& A. ROJAS, 2004, Quaternary continental molluscs from northern Uruguay: distribution and paleoecology. Quaternary International, 114: 123-128. 
MARTORELLI, S., 1987, Estudios parasitológicos en biotopos lénticos de la República Argentina. IV. El ciclo biológico de Echinostoma parcespinosum Lutz, 1924 (Digenea) parásito de Rallus maculatus maculatus y Rallus sanguinolentus sanguinolentus (Aves: Rallidae). Revista del Museo de La Plata, Zoología (Nueva Serie), 14: 48-59.

MATON, W. G., 1811, Description of seven new species of Testacea. The Transactions of the Linnean Society of London, 10: 325-332, pl. 24.

MATSUKURA, K., H. TSUMUKI, Y. IZUMI \& T. WADA, 2008, Changes in chemical components in the freshwater apple snail, Pomacea canaliculata (Gastropoda: Ampullariidae), in relation to the development of its cold hardiness. Cryobiology, 56: 131-137.

MATSUKURA, K., H. TSUMUKI, Y. IZUMI \& T. WADA, 2009a, Physiological response to low temperature in the freshwater apple snail, Pomacea canaliculata (Gastropoda: Ampullariidae). Journal of Experimental Biology, 212: 2558-2563

MATSUKURA, K., H. TSUMUKI, Y. IZUMI \& T WADA, 2009b, Temperature and water availability affect decrease of cold hardiness in the apple snail, Pomacea canaliculata. Malacologia, 51: 263-269.

MATSUKURA, K. \& T. WADA, 2007, Environmental factors affecting the increase of cold hardiness in the apple snail Pomacea canaliculata (Gastropoda: Ampullariidae). Applied Entomology and Zoology, 42: 533-539.

MATTOS, A. C., M. F. F. BOAVENTURA, M. A FERNANDEZ \& S. C. THIENGO, 2013, Larval trematodes in freshwater gastropods from Mato Grosso, Brazil: diversity and host-parasites relationships. Biota Neotropica, 13: 34-38

McARTHUR, A. G. \& M. G. HARASEWYCH, 2003, Molecular systematics of the major lineages of the Gastropoda. Pp. 140-160, in: C. LYDEARD \& D. R. LINDBERG, eds., Molecular systematics and phylogeography of mollusks. Smithsonian Institution, Washington, D.C., xiii + [i] + 328 pp.

McCULLOUGH, F. S., 1964, Observations on bilha rziasis and the potential snail hosts in the Republic of the Congo (Brazzaville). Bulletin of the World Health Organization, 30: 375-388.

McCLARY, A., 1964, Surface inspiration and ciliary feeding in Pomacea paludosa (Prosobranchia: Mesogastropoda: Ampullariidae). Malacologia, 2: 87-104

McKENNA, M. C., 1973, Sweepstakes, filters, corridors, Noah's Arks, and beached Viking funeral ships in palaeogeography. Pp. 295-308, in: D. H. TARLING \& S. K. RUNCORN, eds., Implications of continental drift to the earth sciences. Academic Press, London, $622 \mathrm{pp}$

MEENAKSHI, V. R., 1955, The excretory spherioles in the digestive gland of Pila virens. Journal of Animal Morphology and Physiology, 3: 75-78.

MEENAKSHI, V. R., 1956, Physiology of hibernation of the apple-snail Pila virens (Lamarck). Current Science, 25: 321-322.

MEENAKSHI, V. R., 1957, Anaerobiosis in the south Indian apple-snail Pila virens (Lamarck) during aestivation. Journal of the Zoological Society of India, 9: 62-71.

MEENAKSHI, V. R., 1964, Aestivation in the Indian apple snail Pila-I. Adaptation in natural and experimental conditions. Comparative Biochemistry and Physiology, 11: 379-386.

MELO, L. E. L., R. A. COLER, T. WATANABE \& J. F. BATALLA, 2000, Developing the gastropod Pomacea lineata (Spix, 1827) as a toxicity test organism. Hydrobiologia, 429: 73-78.

MERCADO-LACZKÓ, A. \& E. LOPRETTO, 1998, Estudio cromosómico y cariotípico de Pomacea canaliculata (Lamarck, 1801) (Gastropoda: Ampullariidae). Revista del Museo Argentino de Ciencias Naturales 'Bernardino Rivadavia', Hidrobiología, 8: 15-20.

MICHAUD, M. R., J. B. BENOIT, G. LOPESMARTINEZ, M. A. ELNITSKY, R. E. LEE, JR. \& D. L. DENLINGER, 2008, Metabolomics reveals unique and shared metabolic changes in response to heat shock, freezing and desiccation in the Antarctic midge, Belgica antarctica. Journal of Insect Physiology, 54: 645-655.

MÖLLENDORFF, O. von, 1898, Zur Hochgebirgsfauna der Philippinen. Nachrichtsblatt der Deutschen Malakozoologischen Gesellschaft, 30: 5-12.

MONEVA, C. S. O., M. A. J. TORRES, T. WADA, R. JOSHI \& C. G. DEMAYO, 2012, Relative warp and correlation analysis based on distances of the morphological shell shape patterns of Pomacea canaliculata Lamarck from Japan and Philippines. International Journal of the Bioflux Society, 4: 12-21.

MONTEIL, J. F. \& M. MATRICON-GONDRAN, 1991. Hemocyte production in trematodeinfected Lymnaea truncatula. Parasitology Research, 77: 491-497.

MORASSUTTI, A. L., S. C. THIENGO, M. FERNANDEZ, K. SAWANYAWISUTH \& C. GRAEFF-TEIXEIRA, 2014, Eosinophilic meningitis caused by Angiostrongylus cantonensis: an emergent diseasse in Brazil. Memórias do Instituto Oswaldo Cruz, 109: 399-407.

MORELET, A., [1849], Testacea quædam Africæ occidentalis terrestria et fluviatilia. Revue Zoologique, par la Société Cuvierienne, 11(12) [1848]: 351-355.

MORLET, L., 1889, Catalogue des coquilles recueillies, par M. Pavie, dans le Cambodge et le Royaume de Siam et description d'espèces nouvelles. Journal de Conchyliologie, 37: 121-200, pls. 6-9.

MORRISON, W. E. \& M. E. HAY, 2011a, Feeding and growth of native, invasive and non-invasive alien apple snails (Ampullariidae) in the United States: invasives eat more and grow more. Biological Invasions, 13: 945-955.

MORRISON, W. E. \& M. E. HAY, 2011b, Induced chemical defenses in a freshwater macrophyte suppress herbivore fitness and the growth of associated microbes. Oecologia, 165: 427-436.

MOUSSON, A., [1849], Über die Land- und Süsswasser-Mollusken von Java. Mittheilungen der Naturforschenden Gesellschaft in Zürich, 1(3)(30) [1848]: 264-273. 
MÜLLER, O. F., 1774, Vermium terrestrum et fluviatilium, seu animalium infusoriorum, helminthicorum, et testaceorum, non marinorum, succincta historia. Volumen alterum. Heineck \& Faber, Havniae [= Copenhagen] \& Lipsiae [= Leipzig].

MULLER, R., 2002, Worms and human disease, $2^{\text {nd }}$ ed. CABI Publishing, Wallingford, ix +300 pp.

MURPHY, G. S. \& S. JOHNSON, 2013, Clinical aspects of eosinophilic meningitis and meningoencephalitis caused by Angiostrongylus cantonensis, the rat lungworm. Hawai'i Journal of Medicine and Public Health, 72 (Suppl. 2): 35-40.

NDIFON, G. T. \& F. M. A. UKOLI, 1989, Ecology of freshwater snails in south-western Nigeria. I: Distribution and habitat preferences. Hydrobiologia, 171: 231-253.

NELSON, D. \& M. COX, 2004, Lehninger principles of biochemistry, $4^{\text {th }}$ ed. W. H. Freeman \& Co, New York, $1119+17$ pp.

NG, T. H. \& S. K. TAN, 2011, Observations of land snails feeding on the eggs of Pomacea canaliculata (Lamarck, 1822) (Mollusca: Gastropoda). Nature in Singapore, 4: 79-83.

NG, T. H., S. K. TAN \& M. E. Y. LOW, 2014, Singapore Mollusca: 7 . The family Ampullariidae (Gastropoda: Caenogastropoda: Ampullarioidea). Nature in Singapore, 7: 31-47.

NISHIKAWA, J., S. MAMIYA, T. KANAYAMA, T. NISHIKAWA, F. SHIRAISHI \& T. HORIGUCHI, 2004 , Involvement of the retinoid $X$ receptor in the development of imposex caused by organotins in gastropods. Environmental Science and Technology, 38: 6271-6276.

NONO, A. M. \& A. M. MANE, 1931, Biology of cohol (Ampullaria luzonica Reeve) a common Philippine fresh-water snail. The Phillipine Agriculturist, 19: 675-695.

NORDEN, D. A., 1972, The inhibition of trypsin and some other proteases by ovorubin, a protein from the eggs of Pomacea canaliculata. Comparative Biochemistry and Physiology B, 42: 569-576.

OEHLMANN, J., U. SCHULTE-OEHLMANN, M. TILLMANN \& B. MARKERT, 2000, Effects of endocrine disruptors on prosobranch snails (Mollusca: Gastropoda) in the laboratory. Part I: bisphenol A and octylphenol as xeno-estrogens. Ecotoxicology, 9: 383-397.

OEHLMANN, J., U. SCHULTE-OEHLMANN, J. BACHMANN, M. OETKEN, I. LUTZ, W. KLOAS \& T. A. TERNES, 2006, Bisphenol A induces superfeminization in the ramshorn snail Marisa cornuarietis(Gastropoda: Prosobranchia) at environmentally relevant concentrations. Environmental Health Perspectives, 14 (Suppl. 1): 127-133.

OEHLMANN, J., P. DI BENEDETTO, M. TILLMANN, M. DUFT, M. OETKEN \& U. SCHULTE-OEHLMANN, 2007, Endocrine discruption in prosobranch molluscs: evidence and ecological relevance. Ecotoxicology, 16: 29-43.

O'HARE, N. K., 2010, Florida apple snail (Pomacea paludosa) reproduction in restored and natural seasonal wetlands in Everglades $\mathrm{Na}$ tional Park. Wetlands, 30: 1045-1052.

OLIVIER, G. A., 1804, Voyage dans l'Empire Othoman, l'Egypte et la Perse, fait par ordre du Gouvernement, pendant les six premières années de la République. 4to edition. Tome second. Henri Agasse, Paris, ii $+466+[1]$ p.

OMUDU, E. A. \& A. IYOUGH, 2005, Ecological studies of the gastropod fauna of some minor tributaries of river Benue in Makurdi, Nigeria. Animal Research International, 2: 306-310.

ORBIGNY, A. [D.] d', 1835, Synopsis terrestrium et fluviatilium molluscorum, in suo per Americam meridionalem itinere. Magasin de Zoologie, 5(61-62): 1-44.

ORBIGNY, A. [D.] d', 1838, 1847 [1834-1847], Voyage dans l'Amérique Méridionale (le Brésil, la république orientale de l'Uruguay, la république Argentine, la Patagonie, la république du Chili, la république de Bolivia, la république du Pérou), exécuté pendant les années 1826, 1827, 1828, $1829,1839,1831,1832$ et 1833. Tome cinquième. 3e partie: mollusques, 758 pp., 85 pls. P. Bertrand, Paris; Ve Levrault, Strasbourg.

OSTROWSKI DE NUÑEZ, M., 1979, Ungewöhnliche Xiphidiocercarie aus Ampullaria canaliculata nebst Bemerkungen über Travtrema stenocotyle. Angewandte Parasitologie, 20: 46-52.

OTTAVIANI, E., 1991, Tissue distribution and levels of natural and induced serum lysozyme immunoreactive molecules in a freshwater snail. Tissue and Cell, 23: 317-324.

OTTAVIANI, E., 2006, Molluscan immunorecognition. Invertebrate Survival Journal, 3: 50-63.

OTTAVIANI, E., 2011, Immunocyte: the invertebrate counterpart of the vertebrate macrophage. Invertebrate Survival Journal, 8: 1-4.

OTTAVIANI, E., A. COSSARIZZA, C. ORTOLANI, D. MONTI \& C. FRANCESCHI, 1991, ACTH-like molecules in gastropod molluscs: a possible role in ancestral immune response and stress. Proceedings of the Royal Society of London. Series B, Biological Sciences, 245: 215-218.

OWOJORI, O. J., S. O. ASAOLU \&I. E. OFOEZIE, 2006, Ecology of freshwater snails in Opa Reservoir and research farm ponds at Obafemi Awolowo University Ile-Ife, Nigeria. Journal of Applied Sciences, 6: 3004-3015.

OYA, S., Y. HIRAI \& Y. MIYAHARA, 1987, Overwintering of the apple snail, Pomacea canaliculata Lamarck, in North Kyushu. Japanese Journal of Applied Entomology and Zoology, 31: 206-212.

PASQUEVICH, M. Y., M. S. DREON \& H. HERAS, 2014, The major egg reserve protein from the invasive apple snail Pomacea maculata is a complex carotenoprotein related to those of Pomacea canaliculata and Pomacea scalaris. Comparative Biochemistry and Physiology, Part B, Biochemistry and Molecular Biology, 169: 63-71.

PEÑA, S. C. \& G. N. POCSIDIO, 2007, Influence of copper on the feeding rate, growth and reproduction of the golden apple snail, Pomacea canaliculata Lamarck. Bulletin of Environmental Contamination and Toxicology, 79: 606-608. 
PERERA, G. \& J. G. WALLS, 1996, Apple snails in the aquarium. T.F.H. Publications, Neptune City, New Jersey, U.S.A., 121 pp.

PERERA, G. \& M. YONG, 1984, The influence of some abiotic factors on the distribution of freshwater mollusks on the Isle of Youth (Isle of Pines), Cuba. Walkerana, 2: 131-139.

PERRY, G., 1810-1811, Arcana; or the museum of natural history. Stratford, London.

PEUMANS, W. J. \& E. J. VAN DAMME, 1995 Lectins as plant defense proteins. Plant Physiology, 109: 347-352

PHILLIPS, C. T., M. L. ALEXANDER \& R. HOWARD, 2010, Consumption of eggs of the endangered fountain darter (Etheostoma fonticola) by native and nonnative snails. The Southwestern Naturalist, 55: 115-117.

PICKETT, J. A. \& J. M. EDWARDSON, 2006 Compound exocytosis: mechanisms and functional significance. Traffic 7: 109-116.

PILSBRY, H. A. \& J. T. BEQUAERT, 1927, The aquatic mollusks of the Belgian Congo. With a geographical and ecological account of Congo malacology. Bulletin of the American Museum of Natural History, 53(2): 69-602, pls. 10-77.

PIZANI, N., A. L. ESTEBENET \& P. R. MARTÍN, 2005, Effects of submersion and aerial exposure on clutches and hatchlings of Pomacea canaliculata (Gastropoda: Ampullariidae). American Malacological Bulletin, 20: 55-63.

POINTIER, J.-P., A. THÉRON \& D. IMBERTESTABLET, 1988, Decline of a sylvatic focus of Schistosoma mansoni in Guadeloupe (French West Indies) following competitive displacement of the snail host Biomphalaria glabrata by Ampullaria glauca. Oecologia, 75: 38-43.

POINTIER, J.-P., A. THÉRON, D. IMBERTESTABLET \& G. BOREL, 1991, Eradication of a sylvatic focus of Schistosoma mansoni using biological control by competitor snails. Biological Control, 1: 244-247.

POMACEA PROJECT, 2013, Literature review of Florida apple snails and snail kites, and recommendations for their adaptive management. Final report submitted to the National Park Service, Everglades National Park. The Pomacea Project, Inc., Pensacola, Florida. Available at http://www.pomaceaproject.org/.

PONDER, W. F., D. COLGAN, J. HEALY, A. NÜTZEL, L. R. L. SIMONE \& E. E. STRONG, 2008 , Caenogastropod phylogeny. Pp. 329-382. in: W. F. Ponder \& D. R. Lindierg, eds., Phylogeny and evolution of the Mollusca. University of California Press, Berkeley, xi + 269 pp.

PONDER, W. F. \& D. R. LINDBERG, 1997, Towards a phylogeny of gastropod molluscs: an analysis using morphological characters. Zoological Journal of the Linnean Society, 119: 83-265.

PRASHAD, B., 1925a, On a fossil ampullariid from Poonch, Kashmir. Records of the Geological Survey of India, 56(3): 210-212, pl. 15.

PRASHAD, B., 1925b, Revision of the Indian Ampullariidae. Memoirs of the Indian Museum, 8: 69-89, pls. 13-15.
PRASHAD, B., 1925c, Anatomy of the common Indian apple-snail, Pila globosa. Memoirs of the Indian Museum, 8: 91-154.

PRZESLAWSKI, R., 2004, A review of the effects of environmental stress on embryonic development within intertidal gastropod egg masses. Molluscan Research, 24: 43-63.

PUNYAGUPTA, S., 1965, Eosinophilic meningoencephalitis in Thailand: summary of nine cases and observations on Angiostrongylus cantonensis as a causative agent and Pila ampullacea as a new intermediate host. American Journal of Tropical Medicine and Hygiene, 14: 370-374.

QIU, J.-W., M. T. CHAN, K. L. KWONG \& J. SUN, 2011, Consumption, survival and growth in the invasive freshwater snail Pomacea canaliculata: does food freshness matter? Journal of Molluscan Studies, 77: 189-195.

QIU, J.-W. \& K.-L. KWONG, 2009, Effects of macrophytes on feeding and life-history traits of the invasive apple snail Pomacea canaliculata. Freshwater Biology, 54: 1720-1730.

RAMNARINE, I. W., 2003, Induction of spawning and artificial incubation of eggs in the edible snail Pomacea urceus (Muller) [sic]. Aquaculture, 215: 163-166.

RAMOS-VASCONCELOS, G., L. CARDOSO \& M. HERMES-LIMA, 2005, Seasonal modulation of free radical metabolism in estivating land snails Helix aspersa. Comparative Biochemistry and Physiology C, 140: 165-174.

RANJAH, A. R., 1942, The embryology of the Indian apple-snail Pila globosa (Swainson) (Mollusca, Gastropoda). Records of the Indian Museum, 44: 217-322.

RAUT, S., 1984, On the egg laying behaviour of the apple snail Pila globosa (Swainson) (Mollusca: Gastropoda). Science and Culture, 50: 198-199.

RAWLINGS, T. A., K. A. HAYES, R. H. COWIE \& T. M. COLLINS, 2007, The identity, distribution, and impacts of non-native apple snails in the continental United States. BMC Evolutionary Biology, 7: 97 [14 pp.].

RAY, M., N. S. BHUNIA, A. S. BHUNIA \& S. RAY, 2012, A comparative analyses [sic] of morphological variations, phagocytosis and generation of cytotoxic agents in flow cytometrically isolated hemocytes of Indian molluscs. Fish \& Shellfish Immunology, 34: 244-253

REDDY, Y. S., P. V. RAO \& K. S. SWAMI, 1974, Probable significance of urea and uric acid accumulation during aestivation in the gastropod, Pila globosa (Swainson). Indian Journal of Experimental Biology, 12: 454-456.

REED, W. L. \& F. J. JANZEN, 1999, Natural selection by avian predators on size and colour of a freshwater snail (Pornacea flagellata). Biological Journal of the Linnean Society, 67: 331-342.

REEVE, L. [A.], 1856, Monograph of the genus Ampullaria. Pls. 1-28, in: L. [A.] ReEve, Conchologia Iconica: or, illustrations of the shells of molIuscous animals. Vol. X. Lovell Reeve, London.

$\mathrm{RICH}, \mathrm{E} . \mathrm{R} ., 1990$, Observations on feeding by Pomacea paludosa. Florida Scientist, 53: 13. 
RING, R. A. \& H. V. DANKS, 1994, Desiccation and cryoprotection: overlapping adaptations. CryoLetters, 15: 181-190.

RINGUELET, R., 1945, Hirudíneos del Museo de La Plata. Revista del Museo de La Plata (Nueva Serie) Zoología, 4: 95-137.

RINGUELET, R., 1985, Annulata Hirudinea. Fauna de agua dulce de la Republica Argentina, 27: 1-321

RODRIGUEZ, R., R. M. DEQUI, L. PERUZZO, P. M. MESQUITA, E. GARCIA \& F. FORNARI, 2008, Abdominal angiostrongyliasis: report of two cases with different clinical presentations. Revista do Instituto de Medicina Tropical de São Paulo, 50: 339-341.

RODRIGUEZ, C., I. A. VEGA, J. A. CUETO \& A. CASTRO-VAZQUEZ, 2012, Hemocyte spheroidal aggregates in the kidney and lung of the apple-snail (Pomacea canaliculata) after an immune challenge. Biocell, 36: A113.

ROGEVICH, E. C., T. C. HOANG \& G. M. RAND, 2008 , The effects of water quality and age on the acute toxicity of copper to the Florida apple snail, Pomacea paludosa. Archives of Environmental Contamination and Toxicology, 54: 690-696.

ROMER, A. J., Jr., 1972, The aposomatic [sic] eggs of Pomacea paludosa (Say). MS thesis, University of South Florida, Tampa, vi + $44 \mathrm{p}$

RONDELAUD, D. \& D. BARTHE, 1982, Relationship of the amebocyte-producing organ with the generalized amoebocytic reaction in Lymnaea truncatula Müller infected by Fasciola hepatica L. International Journal of Parasitology, 68: 967-969.

ROUSE, G. W. \& B. G. M. JAMIESON, 1987, An ultrastructural study of the spermatozoa of the polychaetes Eurythoe complanata (Amphinomidae), Clymenella sp. and Micromaldane sp. (Micromaldanidae), with definitions of sperm types in relation to reproductive biology. Journal of Submicroscopical Cytology, 19: 573-584.

RUELLAN, L. \& D. RONDELAUD, 1992, Lamellar structure of the amoebocyte-producing tissue in Lymnaea truncatula infected with Fasciola hepatica. Parasitology Research, 78: 270-272

RUTSCHMANN, F., T. ERIKSSON, J. SCHONENBERGER \& E. CONTI, 2004, Did Crypteroniaceae really disperse out of India? Molecular dating evidence from rbcL, ndhF, and rp/16 intron sequences. International Journal of Plant Science, 164: S69-S83.

SACHWATKIN, V., 1920, Das Urogenitalsystem von Ampullaria gigas Spix. Acta Zoologica, 1: 67-130.

SANTOS, C. A. Z. \& E. G. MENDES, 1981, Oxygen consumption of the amphibious snail Pomacea lineata; influence of weight, sex and environments. Comparative Biochemistry and Physiology A, 69: 595-598.

SAVEANU, L. \& P. R. MARTÍN, 2013, Pedal surface collecting as an alternative feeding mechanism of the invasive apple snail Pomacea canaliculata (Caenogastropoda: Ampullariidae). Journal of Molluscan Studies, 79: 11-18.
SAVEANU, L. \& P. R. MARTÍN, 2014, Egg cannibalism in Pomacea canaliculata (Caenogastropoda, Ampullariidae) from southern Pampas: an alternative trophic strategy? Malacologia, 57(2): in press.

SAWANGPROH, W. \& P. POONSWAD, 2010, The population dynamics of Pomacea canaliculata (Lamarck, 1822) in relation to rice cultivation practice and seasons in Nakhon Pathom, Thailand. Khon Kaen University Science Journal, 38: 228-238.

SAWASDEE, B. \& H.-R. KÖHLER, 2009, Embryo toxicity of pesticides and heavy metals to the ramshorn snail, Marisa cornuarietis (Prosobranchia). Chemosphere, 75: 1539-1547.

SAWASDEE, B. \& H.-R. KÖHLER, 2010, Metal sensitivity of the embryonic development of the ramshorn snail Marisa cornuarietis (Prosobranchia). Ecotoxicology, 19: 1487-1495.

SAY, T., 1829, Descriptions of some new terrestrial and fluviatile shells of North America. The Disseminator of Useful Knowledge [New Harmony], 2: 229-230, 244-246, 259-261, 275-277, 291293, 308-310, 323-325, 339-341, 355-356.

SCARABINO, F., 2004, Conservación de la malacofauna Uruguaya. Comunicaciones de la Sociedad Malacológica del Uruguay, 8: 267-273.

SCHNORBACH, H.-J., 1995, The golden apple snail (Pomacea canaliculata Lamarck), an increasingly important pest in rice, and methods of control with Bayluscid. PflanzenschutzNachrichten Bayer, 48: 313-346.

SCHULTE-OEHLMANN, U., C. BETTIN, P. FIORONI, J. OEHLMANN \& E. STROBEN, 1995, Marisa cornuarietis (Gastropoda, Prosobranchia): a potential TBT bioindicator for freshwater environments. Ecotoxicology, 4: 372-384.

SCHULTE-OEHLMANN, U., P. FIORONI, J. OEHLMANN \& E. STROBEN, 1994, The genital system of Marisa cornuarietis (Gastropoda, Ampullariidae) - a morphological and histological analysis. Zoologische Beiträge, (N. F.), 36: 59-81.

SCHULTE-OEHLMANN, U., M. TILLMANN, B. MARKERT, J. OEHLMANN, B. WATERMANN \& S. SCHERF, 2000, Effects of endocrine disruptors on prosobranch snails (Mollusca: Gastropoda) in the laboratory. Part Il: triphenyltin as a xeno-androgen. Ecotoxicology, 9: 399-412.

SEIXAS, S. A., J. F. R. AMATO \& S. B. AMATO, 2010a, First report of Temnocephala haswelli (Platyhelminthes: Temnocephalida) in Pomacea canaliculata (Mollusca: Ampullariidae) from Brazil: description update based on specimens from the state of Rio Grande do Sul, Brazil. Zoologia, 27: 455-464.

SEIXAS, S. A., J. F. R. AMATO \& S. B. AMATO, $2010 b$, First report of Temnocephala rochensis (Platyhelminthes: Temnocephalida) from Pomacea canaliculata (Mollusca: Ampullariidae) outside Uruguay - description update based on specimens from the state of Rio Grande do Sul, Brazil. Zoologia, 27: 820-828.

SEMPER, C., 1862, Entwickelungsgeschichte der Ampullaria polita Deshayes nebst Mittheilungen über die Entwickelungsgeschichte einiger an- 
dern Gastropoden aus den Tropen. C. van der Post Jr., Utrecht, 80 pp.

SEUFFERT, M. E., S. BURELA \& P. R. MARTíN, 2010, Influence of water temperature on the activity of the freshwater snail Pomacea canaliculata (Caenogastropoda: Ampullariidae) at its southernmost limit (Southern Pampas, Argentina). Journal of Thermal Biology, 35: 77-84.

SEUFFERT, M. E. \& P. R. MARTÍN, 2009, Influence of temperature, size and sex on aerial respiration of Pomacea canaliculata (Gastropoda: Ampullariidae) from southern pampas, Argentina. Malacologia, 51: 191-200.

SEUFFERT, M. E. \& P. R. MARTÍN, 2010, Dependence on aerial respiration and its influence on microdistribution in the invasive freshwater snail Pomacea canaliculata (Caenogastropoda, Ampullariidae). Biological Invasions, 12: 1695-1708.

SEUFFERT, M. E. \& P. R. MARTÍN, 2012, A lentic dweller in lotic habitats: the behavior of the invasive South American apple snail Pomacea canaliculata in flowing water. Aquatic Ecology, 46: 129-142.

SEUFFERT, M. E. \& P. R. MARTÍN, 2013a, Distribution of the apple snail Pomacea canaliculata in Pampean streams (Argentina) at different spatial scales. Limnologica, 43: 91-99.

SEUFFERT, M. E. \& P. R. MARTíN, 2013b, Juvenile growth and survival of the apple snail Pomacea canaliculata (Caenogastropoda Ampullariidae) reared at different constant temperatures. SpringerPlus, 2: 312.

SEUFFERT, M. E., L. SAVEANU \& P. R. MARTÍN, 2012, Threshold temperatures and degree-day estimates for embryonic development of the invasive apple snail Pomacea canaliculata (Caenogastropoda: Ampullariidae). Malacologia, 55: 209-217.

SHARFSTEIN, B. \& A. D. STEINMAN, 2001, Growth and survival of the Florida apple snail (Pomacea paludosa) fed 3 naturally occurring macrophyte assemblages. Journal of the North American Benthological Society, 20: 84-95.

SHOZAWA, A. \& C. SUTO, 1990, Hemocytes of Pomacea canaliculata: I. Reversible aggregation induced by $\mathrm{Ca}^{2+}$. Developmental and Comparative Immunology, 14: 175-184.

SHUFORD R. B. E III, P V. McCORMICK \& J. MAGSON, 2005, Habitat related growth of juvenile Florida applesnails (Pomacea paludosa). Florida Scientist, 68: 11-19.

SIMONE, L. R. L., 2004, Comparative morphology and phylogeny of representatives of the superfamilies of Architaenioglossans and the Annulariidae (Mollusca, Caenogastropoda). Arquivos do Museu Nacional, Rio de Janeiro, 62: 387-504.

SJURSEN, H. \& L. SOMME, 2000, Seasonal changes in tolerance to cold and desiccation in Phauloppia sp. (Acari, Oribatida) from Finse, Norway. Journal of Insect Physiology, 40: 1387-1396

SMINIA, T., 1981, Gastropods. Pp. 191-232, in: N. A. RATCLIFFE \& A. RoWLEY, eds., Invertebrate blood cells. Academic Press, New York, 2 Vols.: Iv + 1-[324] pp. (vol. 1), xlv + [325]-641 pp. (Vol. 2).

SNYDER, N. F. R. \& H. W. KALE, II, 1983, Mollusk predation by snail kites in Colombia. The Auk, 100: 93-97.

SNYDER, N. F. R. \& H. A. SNYDER, 1969, A comparative study of mollusc predation by limpkins, everglade kites, and boat-tailed grackles. Living Bird, 8: 177-223.

SNYDER, N. F. R. \& H. A. SNYDER, 1971, Defenses of the Florida apple snail Pomacea paludosa. Behaviour, 40: 175-215, 4 pls.

SOUZA, S. D. S. \& Z. A. ANDRADE, 2006, On the origin of the Biomphalaria glabrata hemocytes. Memórias do Instituto Oswaldo Cruz, 101 (Suppl. 1): 213-218.

SOWERBY, G. B., I, 1825, A catalogue of the shells contained in the collection of the late Earl of Tankerville, arranged according to the Lamarckian conchological system; together with an appendix, containing descriptions of many new species. G. B. Sowerby, London, vii +92 + xxxiv pp., 9 pls.

SPARKS, J. S., 2004, Molecular phylogeny and biogeography of the Malagasy and South Asian cichlids (Teleostei: Perciformes: Cichlidae). Molecular Phylogenetics and Evolution, 30: 599-614.

STAPLES, C. A., K. WOODBURN, N. CASPERS, A. T. HALL \& G. M. KLEČKA, 2002, A weight of evidence approach to the aquatic hazard assessment of bisphenol A. Human and Ecological Risk Assessment, 8: 1083-1105.

STARMÜHLNER, F., 1979, Distribution of freshwater molluscs in mountain streams of tropical Indo-Pacific islands (Madagascar, Ceylon, New Caledonia). Malacologia, 18: 245-255.

STEVENS, A. J., Z. C. WELCH, P. C. DARBY \& H. F. PERCIVAL, 2002, Temperature effects on Florida applesnail activity: implications for snail kite foraging success and distribution. Wildlife Society Bulletin, 30: 75-81.

STOREY, K. B., 2002, Life in the slow lane: molecular mechanisms of estivation. Comparative Biochemistry and Physiology A, 133: 733-754.

STOREY, K. [B.] \& J. STOREY, 1997, To freeze or not to freeze. The Biochemist, 19: 8-13.

STRONG, E. E., 2003, Refining molluscan characters: morphology, character coding and a phylogeny of the Caenogastropoda. Zoological Journal of the Linnean Society, 137: 447-554.

STRONG, E. E., O. GARGOMINY, W. F. PONDER \& P. BOUCHET, 2008, Global diversity of gastropods (Gastropoda: Mollusca) in freshwater. Hydrobiologia, 595: 149-166.

SUN, J., 2013, Characterization of the egg and embryonic proteome of Pomacea canaliculata, and responses of the proteome to environmental stressors. PhD Thesis, Hong Kong Baptist University, Hong Kong.

SUN, J., Y. ZHANG, V. THIYAGARAJAN, P.-Y. QIAN \& J.-W. QIU, 2010, Protein expression during the embryonic development of a gastropod. Proteomics, 10: 2701-2711. 
SUN, J., H. MU, H. ZHANG, K. H. CHANDRAMOULI, P.-Y. QIAN, C. K. C. WONG \& J. W. QIU, 2013, Understanding the regulation of estivation in a freshwater snail through iTRAQbased comparative proteomics. Journal of Proteome Research, 12: 5271-5280.

SUN, J., M. WANG, H. WANG, H. ZHANG, V. THIYAGARAJAN, P.-Y. QIAN \& J.-W. QIU, 2012a, De novo assembly of the transcriptome of an invasive snail and its multiple ecological applications. Molecular Ecology Resources, 12: 1133-1144.

SUN, J., H. ZHANG, H. WANG, H. HERAS, M. S. DREON, S. ITUARTE, T. RAVASI, P.Y. QIAN \& J.-W. QIU, 2012b, First proteome of the egg perivitelline fluid of a freshwater gastropod with aerial oviposition. Journal of Proteome Research, 11: 4240-4248.

SWAINSON, W., 1822 [1821-1823], Zoological illustrations, or original figures and descriptions of new, rare, or interesting animals, selected chiefly from the classes of ornithology, entomology, and conchology, and arranged on the principles of Cuvier and other modern zoologists. Series 1, Vols. II-III: pls. 67-192, pp. [i-xxvii]. Baldwin, Cradock \& Joy, \& W. Wood, London.

TABUGO, S. R. M., M. A. J. TORRES, \& C. G. DEMAYO, 2010, Relative warp and correlation analysis based on distances of the morphological shape of the shell of the golden apple snail Pomacea canaliculata from Iligan City, Philippines. Pp. 81-85, in: S. BABY \& Y. DAN, eds., 2010 International Conference on Environmental Engineering and Applications. 10-12 September, 2010. Singapore. Proceedings. Institute of Electrical and Electronics Engineers, New York, xiv + 349 pp.

TAKEBAYASHI, T. E., 2013, What are the $\mathrm{C}$ and $\mathrm{K}$ corpuscles of apple snails? The Malacologist, 61: 3-5.

TAMBURI, N. E. \& P. R. MARTÍN, 2009a, Reaction norms of size and age at maturity of Pomacea canaliculata (Gastropoda: Ampullariidae) under a gradient of food deprivation. Journal of Molluscan Studies, 75: 19-26.

TAMBURI, N. E. \& P. R. MARTÍN, 2009b, Feeding rates and food conversion efficiencies in the apple snail Pomacea canaliculata (Caenogastropoda: Ampullariidae). Malacologia, 51: 221-232.

TAMBURI, N. E. \& P. R. MARTÍN, 2011, Effects of food availability on reproductive output, offspring quality and reproductive efficiency in the apple snail Pomacea canaliculata. Biological Invasions, 13: 2351-2360.

TAMBURI, N. E. \& P. R. MARTíN, 2012, Effect of food availability on morphometric and somatic indices of the apple snail Pomacea canaliculata (Caenogastopoda, Ampullariidae). Malacologia, 55: 33-41.

TAMBURI, N. E. \& P. R. MARTÍN, 2013, Allometric and trophic effects on shell morphology of Pomacea canaliculata (Caenogastropoda Ampullariidae) from a geometric morphometrics viewpoint. Molluscan Research, 33: 223-229.
TANAKA, K., T. WATANABE, H. HIGUCHI, K. MIYAMOTO, Y. YUSA, T. KIYONAGA, H. KIYOTA, Y. SUZUKI \& T. WADA, 1999, Density-dependent growth and reproduction of the apple snail, Pomacea canaliculata: a density manipulation experiment in a paddy field. Researches on Population Ecology, 41: 253-262.

TANAKA, M. O., A. L. SOUZA \& E. S. MÓDENA, 2006, Habitat structure effects on size selection of snail kites (Rostrhamus sociabilis) and limpkins (Aramus guarauna) when feeding on apple snails (Pomacea spp.). Acta Oecologica, 30: 88-96.

TEEM, J. L., Y. QVARNSTROM, H. S. BISHOP, A. J. DA SILVA, J. CARTER, J. WHITE-MCLEAN \& T. SMITH, 2013, The occurrence of the rat lungworm, Angiostrongylus cantonensis, in nonindigenous snails in the Gulf of Mexico region of the United States. Hawai'i Journal of Medicine and Public Health, 72 (Suppl. 2): 11-14.

TESANA, S., T. SRISAWANGWONG, P. SITHITHAWORN, T. LAHA \& R. ANDREWS, 2009, Prevalence and intensity of infection with third stage larvae of Angiostrongylus cantonensis in mollusks from northeast Thailand. American Journal of Tropical Medecine and Hygiene, 80: 983-987.

THIENGO, S. C., 1987, Observations on the morphology of Pomacea lineata (Spix, 1827) (Mollusca, Ampullariidae). Memórias do Instituto Oswaldo Cruz, 82: 563-570.

THIENGO, S. C., 1989, On Pomacea sordida (Swainson, 1823) (Prosobranchia, Ampullariidae). Memórias do Instituto Oswaldo Cruz, 84: 351-355.

THIENGO, S. C., C. E. BORDA \& J. L. B. ARAÚJO, 1993, On Pomacea canaliculata (Lamarck, 1822) (Mollusca; Pilidae: Ampullariidae). Memórias do Instituto Oswaldo Cruz, 88: 67-71.

THIENGO, S. C., K. A. HAYES, A. C. MATTOS, M. A. FERNANDEZ \& R. H. COWIE, 2011, A Família Ampullariidae no Brasil: aspectos morfológicos, biológicos e taxonômicos. Pp. 95-111, in: M. A. Fernandez, S. B. dos Santos, A. D. Pimenta \& S. C. Thiengo, org., Tópicos em Malacologia. Ecos do XIX Encontro Brasileiro de Malacologia. Sociedade Brasileira de Malacologia, Rio de Janeiro, $x+468$ pp.

THIENGO, S. C., A. MALDONADO, E. M. MOTA, E. J. L. TORRES, R. CALDEIRA, O. S. CARVALHO, A. P. M. OLIVEIRA, R. O. SOMÕES, M. A. FERNANDEZ \& R. M. LANFREDI, 2010, The giant African snail Achatina fulica as natural intermediate host of Angiostrongylus cantonensis in Pernambuco, northeast Brazil. Acta Tropica, 115: 194-199.

THOMAS, M. \& J. AGARD, 1992, Metabolic rate depression in the ampullariid snail Pomacea urceus (Müller) during aestivation and anaerobiosis. Comparative Biochemistry and Physiology A, 102: 675-678.

TIECHER, M. J., S. BURELA \& P. R. MARTÍN, 2014, Mating behavior, egg laying, and embryonic development in the South American 
apple snail Asolene pulchella (Ampullariidae, Caenogastropoda). Invertebrate Reproduction \& Development, 58: 13-22.

TILL-BOTTRAUD, I., D. JOLY, D. LACHAISE, \& R. R. SNOOK, 2005, Pollen and sperm heteromorphism: convergence across kingdoms? Journal of Evolutionary Biology, 18: 1-18.

TILLMANN, M., U. SCHULTE-OEHLMANN, M. DUFT, B. MARKERT \& J. OEHLMANN, 2001, Effects of endocrine disruptors on prosobranch snails (Mollusca: Gastropoda) in the laboratory. Part III: Cyproterone acetate and vinclozolin as antiandrogens. Ecotoxicology, 10: 373-388.

TORRES, M. A., L. R. T. AMARILLO, R. JOSHI, L. SEBASTIAN, Z. BAOANAN \& C. G. DEMAYO 2011 , Intra- and Inter-population variability in the golden apple snail Pomacea canaliculata. Australian Journal of Basic and Applied Sciences, 5: 789-800.

TRAN, C. T., K. A. HAYES \& R. H. COWIE, 2008, Lack of genetic diversity in invasive apple snails (Ampullariidae) in Hawaii. Malacologia, 50: 351-357.

TRAVERS, M.-A., P. M. DA SILVA, N. LE GOÏC, D. MARIE, A. DONVAL, S. HUCHETTE, M. KOKEN \& C. PAILLARD, 2008, Morphologic, cytometric and functional characterisation of abalone (Haliotis tuberculata) haemocytes. Fish and Shellfish Immunology, 24: 400-411.

TROSCHEL, F. H., 1845, Anatomie von Ampullaria urceus und über die Gattung Lanistes Montf. Archiv für Naturgeschichte, 11: 97-216, pl. 8.

TSAI, H.-C., Y.-S. CHEN \& C. M. YEN, 2013, Human Parasitic meningitis caused by $A n-$ giostrongylus cantonensis infection in Taiwan. Hawai'i Journal of Medicine and Public Health, 72 (Suppl. 2): 26-27.

TURNER, R. L., 1994, The effects of hydrology on the population dynamics of the Florida applesnail (Pomacea paludosa). St. Johns River Water Management District, Palatka, Florida, Special Publication, SJ94-SP3: vi + 31 pp.

TURNER, R. L., 1996, Use of stems of emergent plants for oviposition by the Florida applesnail, Pomacea paludosa, and implications for marsh management. Florida Scientist, 59: 34-49.

TURNER, R. L., 1998, Effects of submergence on embryonic survival and developmental rate of the Florida applesnail, Pomacea paludosa: implications for egg predation and marsh management. Florida Scientist, 61: 118-129.

TURNER, R. L. \& C. M. McCABE, 1990, Calcium source for protoconch formation in the Florida apple snail, Pomacea paludosa (Prosobranchia: Pilidae): more evidence for physiological plasticity in the evolution of terrestrial eggs. The Veliger, 33: 185-189.

UESHIMA, E. \& Y. YUSA, 2014, Antipredator behaviour in response to single or combined predator cues in the apple snail Pomacea canaliculata. Journal of Molluscan Studies, Advance Access, doi:10.1093/mollus/eyu057.

UTZ, L. R. P., 2007, First record of Epistylis plicatilis (Ciliophora: Peritrichia) attached to Pomacea canaliculata (Mollusca: Gastropoda) in southern Brazil. Zootaxa, 1454: 49-57.
VAN DER KNAAP, W., C. ADEMA \& T. SMINIA, 1993, Invertebrate blood cells: morphological and functional aspects of the haemocytes in the pond snail Lymnaea stagnalis. Comparative Haematology International, 3: 20-26.

VEGA, I. A., M. A. ARRIBÉRE, A. V. ALMONACID, S. RIBEIRO GUEVARA \& A. CASTROVAZQUEZ, 2012a, Apple snails and their endosymbionts bioconcentrate heavy metals and uranium from contaminated drinking water. Environmental Science and Pollution Research, 19: 3307-3316.

VEGA, I. A., M. C. DAMBORENEA, C. GAMARRA-LUQUES, E. KOCH, J. A. CUETO \& A. CASTRO-VAZQUEZ, 2006, Facultative and obligate symbiotic associations of Pomacea canaliculata (Caenogastropoda, Ampullariidae). Biocell, 30: 367-375.

VEGA, I. A., F. A. DELLAGNOLA, J. A. HURST, M. S. GODOY \& A. CASTRO-VAZQUEZ, 2012b, A study of chlorophyll-like and phycobilin pigments in the $\mathrm{C}$ endosymbiont of the apple-snail Pomacea canaliculata. Biocell, 36: 47-55.

VEGA, I. A., C. GAMARRA-LUQUES, E. KOCH, L. BUSSMANN \&A. CASTRO-VAZQUEZ, 2005, A study of corpuscular DNA and midgut gland occupancy by putative symbiotic elements in Pomacea canaliculata (Caenogastropoda, Ampullariidae). Symbiosis, 39: 37-45.

VEGA, I. A., M. GIRAUD-BILLOUD, E. KOCH, C. GAMARRA-LUQUES \&A. CASTRO-VAZQUEZ, 2007, Uric acid accumulation within intracellular crystalloid corpuscles of the midgut gland in Pomacea canaliculata (Caenogastropoda, Ampullariidae). The Veliger, 48: 276-283.

VON BRAND, E., T. YOKOSAWA \& Y. FUJIO, 1990, Chromosome analysis of apple snail Pomacea canaliculata. Tohoku Journal of Agricultural Research, 40: 81-89.

WADA, T. \& K. MATSUKURA, 2007, Seasonal changes in cold hardiness of the invasive freshwater apple snail, Pomacea canaliculata (Lamarck) (Gastropoda: Ampullariidae). Malacologia, 49: 383-392.

WADA, T. \& K. MATSUKURA, 2011, Linkage of cold hardiness with desiccation tolerance in the invasive freshwater apple snail, Pomacea canaliculata (Caenogastropoda: Ampullariidae). Journal of Molluscan Studies, 77: 149-153.

WADA, T. \& K. YOSHIDA, 2000, Burrowing by the apple snail, Pomacea canaliculata (Lamarck); daily periodicity and factors affecting burrowing. Kyushu Plant Protection Research, 46: 88-93.

WAGNER, J. A., 1827, Testacea fluviatilia quae in itinere per Brasiliam annis MDCCCXVII - MDCCCXX jussu et auspiciis Maximiliani Josephi I. Bavariae regis augustissimi suscepto collegit et pingenda curavit Dr. J. B. de Spix, quondam ordinis regii coronæ Bavaricæ civilis eques, academiæ scientarum Bavaricæ socius ordinarius, musei regii zoologici, zootomici et ethnographici conservator rel. C. Wolf, Monachii, iv + [ii] + 36 pp., 29 pls.

WALLACE, G. D. \& L. ROSEN, 1969, Studies on eosinophilic meningitis V. Molluscan hosts of Angiostrongylus cantonensis on Pacific Islands. 
American Journal of Tropical Medicine and Hygiene, 18: 206-216.

WANG, H.-J., 1984, Two upper Jurassic gastropod opercula in China. Acta Palaeontologica Sinica, 23: 369-372, pl. 1.

WANG, Q.-P., D.-H. LAI, X.-Q. ZHU, X.-G. CHEN \& Z.-R. LUN, 2008, Human angiostrongyliasis. The Lancet Infectious Diseases, 8: 621-630.

WATANABE, T., K. TANAKA, H. HIGUCHI, K. MIYAMOTO, T. KIYONAGA, H. KIYOTA, Y. SUZUKI \& T. WADA, 2000, Emergence of the apple snail, Pomacea canaliculata (Gastropoda: Ampullariidae), after irrigation in a paddy. $A p$ plied Entomology and Zoology, 35: 75-79.

WEERACHAI, S., P. SITHITHAWORN, K. DUENNGAI, N. KIATSOPIT, R. H. ANDREWS \& T. N. PETNEY, 2011, Genetic variation and relationshipsof four species of medically important echinostomes (Trematoda: Echinostomatidae) in South-East Asia. Infection, Genetics and Evolution, 11: 375-381.

WHITMAN, D. W. \& A. A. AGRAWAL, 2009 , What is phenotypic plasticity and why is it important? Pp. 1-63, in: D. W. WhitMAn \& T. N. AnAnthakrishna, eds., Phenotypic plasticity of insects: mechanisms and consequences. Science Publishers, Inc., Enfield, x + 894 pp.

WINIK, B. C. \& A. CASTRO-VAZQUEZ, 2015, Adaptations to frequent oocyte release in the ovary of the invasive snail Pomacea canaliculata (Caenogastropoda, Ampullariidae). Journal of Molluscan Studies, doi: 10.1093/mollus/ eyu078

WINIK, B., N. CATALÁN, C. GAMARRA-LUQUES \&A. CASTRO-VAZQUEZ, 2009, Ectaquaspermlike parasperm in an internally fertilizing gastropod. Invertebrate Biology, 128: 223-231.

WINIK, B. C., N. M. Y. CATALÁN \& O. C. SCHLICK, 2001 , Genesis of the apyrene parasperm in the apple snail Pomacea canaliculata (Gastropoda, Ampullariidae): an ultrastructural study. Journal of Molluscan Studies, 67: 81-93.

WINIK, B., C. SCHLICK \& M. CATALÁN, 1994, Fine structure of Sertoli cells in the pond snail Ampullaria canaliculata (Gastropoda, Prosobranchia) Biocell, 18: 59-73.

WITHERS, P., M. GUPPY \& S. PEDLER, 1996, Physiological adjustments during aestivation by the Australian land snail Rhagada tescorum (Mollusca: Pulmonata: Camaenidae). Australian Journal of Zoology, 45: 599-611.

WONG, P. K., K. L. KWONG \& J.-W. QIU, 2009, Complex interactions among fish, snails and macrophytes: implications for biological control of an invasive snail. Biological Invasions, 11: 2223-2232.

WONG, P. K., Y. LIANG, N. Y. LIU \& J.-W. QIU, 2010, Palatability of macrophytes to the invasive freshwater snail Pomacea canaliculata: differential effects of multiple plant traits. Freshwater Biology, 55: 2023-2031.

WOOD, T. S., P. ANURAKPONGSATORN, R. CHAICHANA, J. MAHUJCHARIYAWONG \& T. SATAPANAJARU, 2005, Predation on freshwater bryozoans by the apple snail, Pomacea canaliculata, Ampullariidae, an invasive species in Southeast Asia: a summary report. Denisia, Neue Serie, 28: 283-286.

WOOD, T. S., P. ANURAKPONGSATORN, R. CHAICHANA, J. MAHUJCHARIYAWONG \& T. SATAPANAJARU, 2006, Heavy predation on freshwater bryozoans by the golden apple snail, Pomacea canaliculata Lamarck, 1822 (Ampullariidae). Natural History Journal of Chulalongkorn University, 6: 31-36.

WOOD, W., 1828, Supplement to the Index Testaceologicus; or a catalogue of shells, British and foreign. W. Wood, London, vi + 59 pp., 8 pls.

YAMANISHI, Y., K. YOSHIDA, N. FUJIMORI \& Y. YUSA, 2012, Predator-driven biotic resistance and propagule pressure regulate the invasive apple snail Pomacea canaliculata in Japan. Biological Invasions, 14: 1343-1352.

YAMAURA, I., T. KOGA, T. MATSUMOTO \& T. KATO, 1997, Purification and some properties of endo-1, 4- $\beta$-D-xylanase from a fresh-water mollusc, Pomacea insularus (de Ordigny) [sic]. Bioscience, Biotechnology, and Biochemistry, 61: 615-620.

YAMAURA, I. \& T. MATSUMOTO, 1993, Purification and some properties of endo-1,4$\beta$-D-mannanase from a mud snail, Pomacea insularus (de Ordigny) [sic]. Bioscience, Biotechnology, and Biochemistry, 57: 1316-1319.

YANG, T.-B., Z.-D. WU \& Z.-R. LUN, 2013, The apple snail Pomacea canaliculata, a novel vector of the rat lungworm, Angiostrongylus cantonensis: its introduction, spread, and control in China. Hawai'i Journal of Medicine and Public Health, 72(6) (Suppl. 2): 23-25.

YASEEN, A., A. EBAID \& I. KAWASHTI, 1991, Studies on the chromosomal analysis and shell measurements of two species, Bellamya unicolor and Lanistes bolteni (Prosobranchiata: Gastropoda). Cytologia, 56: 503-509.

YOSHIE, H. \& Y. YUSA, 2008, Effects of predation on the exotic freshwater snail Pomacea canaliculata (Caenogastropoda: Ampullariidae) by the indigenous turtle Chinemys reevesii (Testudines: Geoemydidae). Applied Entomology and Zoology, 43: 475-482.

YOSHIDA, K., K. HOSHIKAWA, T. WADA \& $Y$. YUSA, 2009, Life cycle of the apple snail Pomacea canaliculata (Caenogastropoda: Ampullariidae) inhabiting Japanese paddy fields. Applied Entomology and Zoology, 44: 465-474.

YOSHIDA, K., K. HOSHIKAWA, T. WADA \& Y. YUSA, 2013, Patterns of density dependence in growth, reproduction and survival in the invasive freshwater snail Pomacea canaliculata in Japanese rice fields. Freshwater Biology, 58: 2065-2073.

YOSHIDA, K., K. MATSUKURA, N. J. CAZZANIGA \& T. WADA, 2014. Tolerance to low temperature and desiccation in two invasive apple snails, Pomacea canaliculata and $P$. maculata (Caenogastropida: Ampullariidae) collected in their original distribution area (northern and central Argentina). Journal of Molluscan Studies, 80: 62-66.

YOUENS, A. K. \& R. L. BURKS, 2008, Comparing applesnails with oranges: the need to standard- 
ize measuring techniques when studying Pomacea. Aquatic Ecology, 42: 679-684.

YOUSIF, F., S. BLÄHSER \& G. LÄMMLER, 1980, The cellular responses in Marisa cornaurietis experimentally infected with Angiostrongylus cantonensis. Zeitschrift für Parasitenkunde, 62: 179-190.

YUSA, Y., 2001, Predation on eggs of the apple snail Pomacea canaliculata (Gastropoda: Ampullariidae) by the fire ant Solenopsis geminata. Journal of Molluscan Studies, 67: 275-279.

YUSA, Y., 2004a, Inheritance of colour polymorphism and the pattern of sperm competition in the apple snail Pomacea canaliculata (Gastropoda: Ampullariidae). Journal of Molluscan Studies, 70: 43-48.

YUSA, Y., 2004b, Brood sex ratio in the apple snail Pomacea canaliculata (Gastropoda: Ampullariidae) is determined genetically and not by environmental factors. Journal of Molluscan Studies, 70: 269-275.

YUSA, Y., 2006a, Genetics of sex-ratio variation inferred from parent-offspring regressions and sib correlations in the apple snail Pomacea canaliculata. Heredity, 96: 100-105.

YUSA, Y., 2006b, Predators of the introduced apple snail, Pomacea canaliculata (Gastropoda: Ampullariidae): their effectivenss and utilization in biological control. Pp. 345-361, in: R. C. JosH \& L. C. SEBASTIAN, eds., Global advances in ecology and management of golden apple snails. Philippine Rice Research Institute, Muñoz, Nueva Ecija, Philippines, $x+588$ pp.

YUSA, Y., 2007a, Causes of variation in sex ratio and modes of sex determination in the Mollusca - an overview. American Malacological Bulletin, 23: 89-98.
YUSA, Y., 2007b, Nuclear sex-determining genes cause large sex-ratio variation in the apple snail Pomacea canaliculata. Genetics, 175: 179-184.

YUSA, Y., N. SUGIURA \& K. ICHINOSE, 2000, Predation on the apple snail, Pomacea canaliculata (Ampullariidae), by the Norway rat, Rattus norvegicus, in the field. The Veliger, 43: 349-353.

YUSA, Y., N. SUGIURA \& T. WADA., 2006b, Predatory potential of freshwater animals on an invasive agricultural pest, the apple snail Pomacea canaliculata (Gastropoda: Ampullariidae), in southern Japan. Biological Invasions, 8: 137-147.

YUSA, Y. \& Y. SUZUKI, 2003, A snail with unbiased population sex ratios but highly biased brood sex ratios. Proceedings of the Royal Society of London B, 270: 283-288.

YUSA, Y., T. WADA \& S. TAKAHASHI, 2006a, Effects of dormant duration, body size, self-burial and water condition on the long-term survival of the apple snail, Pomacea canaliculata (Gastropoda: Ampullariidae). Applied Entomology and Zoology, 41: 627-632.

ZHANG, S., Q. Y. YIN, Y. H. LI, M. DING, G. J. XU \& F. K. ZHAO, 2007, Molecular and biochemical characterization of Ba-EGA, a cellulase secreted by Bacillus sp. AC-1 from Ampullaria crosseans [sic]. Applied Microbiology and Biotechnology, 75: 1327-1334.

ZHOU, W. C., Y. F. WU \& J. Q. YANG, 2003, Viability of Ampullaria snail in China. Fujian Journal of Agricultural Sciences, 18: 25-28.

Revised ms. accepted November 8, 2014 